\title{
WestVirginiaUniversity
}

THE RESEARCH REPOSITORY @ WVU

Graduate Theses, Dissertations, and Problem Reports

1999

\section{Protecting property rights in America}

Alfred M. Olivetti

West Virginia University

Follow this and additional works at: https://researchrepository.wvu.edu/etd

\section{Recommended Citation}

Olivetti, Alfred M., "Protecting property rights in America" (1999). Graduate Theses, Dissertations, and Problem Reports. 3168.

https://researchrepository.wvu.edu/etd/3168

This Dissertation is protected by copyright and/or related rights. It has been brought to you by the The Research Repository @ WVU with permission from the rights-holder(s). You are free to use this Dissertation in any way that is permitted by the copyright and related rights legislation that applies to your use. For other uses you must obtain permission from the rights-holder(s) directly, unless additional rights are indicated by a Creative Commons license in the record and/ or on the work itself. This Dissertation has been accepted for inclusion in WVU Graduate Theses, Dissertations, and Problem Reports collection by an authorized administrator of The Research Repository @ WVU.

For more information, please contact researchrepository@mail.wvu.edu. 


\title{
Protecting Property Rights in America
}

Alfred M. Olivetti

Dissertation submitted to the Eberly College of Arts and Sciences at West Virginia University in partial fulfillment of the requirements for the degree of

\author{
Doctor of Philosophy \\ in \\ Public Policy
}

\author{
Jeffrey S. Worsham, Ph.D., Chair \\ John C. Kilwein, Ph.D. \\ Christopher Z. Mooney, Ph.D. \\ Chris L. Plein, Ph.D. \\ Neil. B. Berch, Ph.D.
}

Department of Political Science

Morgantown, West Virginia

1999

Keywords: property rights, regulatory takings, agenda setting, venue shifting, issue definition 


\title{
ABSTRACT \\ Protecting Property Rights in America
}

\begin{abstract}
Alfred M. Olivetti
To date, no federal takings legislation has been passed to protect individuals from government regulations that 'take' one's property without providing just compensation. However, since 1991, twenty states have passed some type of takings legislation. This study examines the following questions: What has been happening in Congress concerning the property rights issue and why has it failed to pass substantive federal takings legislation? Why did the proponents of takings legislation seek to move the issue to a larger venue beyond Congressional committees? And, what tactics did the proponents of takings legislation use to capture the political agenda regarding this issue at the state level? I test theories of agenda setting, particulary Baumgartner and Jones's (1993) dual mobilization theory, venue shifting, and issue expansion to describe the battle for control over the political agenda regarding the property rights issue in America. I employ data gathered from Congressional committee hearings concerning property matters, including property rights and regulatory takings, from 1959 - 1995 and interviews with people closely involved with the issue to explain the political circumstances of the property rights issue. I use the hearings' data to study for the tone, the participants, jurisdictional control, and the use of nonlegislative hearings to come to some determinations regarding the agenda battle over the property rights issue. Also, I use interview data and previous research to try to explain the issue's vertical shift of venues and why some states enact takings legislation and other do not. This study provides evidence that the property rights community has mobilized and successfully challenged for control of the political agenda in Congress regarding the property rights issue. Also, it suggests that the jurisdictional control over property matters in Congress by committees that are traditionally unfavorable to property rights interests have prevented the passing of any substantive federal takings legislation. I find that committee chairs used nonlegislative hearings as a forum accessible to rival interests to express their views. And, venue shifting was not a strategy employed by the property rights community to gain agenda control in the states. This is the first comprehensive political analysis of the property rights issue in America. My findings contribute to the contemporary knowledge regarding agenda setting and venue shifting, as well as set the stage for a deeper analysis of state level action concerning the property rights issue.
\end{abstract}




\section{ACKNOWLEDGMENTS}

Thanks to mother and father for your unconditional love, encouragement, and support not only during my Ph.D. years, but throughout my life. Your importance in my life is immeasurable and you both deserve credit for all that I accomplish. Thanks to Mike, Lisa, Vince, Stacey and our growing family for being great brothers, sisters, and friends. I am fortunate and proud to be surrounded by such a wonderful group of people. Thanks to Jeff Worsham whose support, guidance, and exceptional ability to conceptualize a study made all the difference in the world. Thanks also to John Kilwein, Chris Mooney, Chris Plein, and Neil Berch for their contributions in completing this study. Thanks to everyone within the department of political science, especially Dr. Hammock and Lee Ann Greathouse who made the tasks of being a graduate student more bearable and made it easy to walk the halls of the third floor with a smile. Thanks to my friends here in Morgantown for allowing me to be part of a community that is never short of goodwill, humor, and miles of training. Finally, thanks to all my close friends that have contributed to my life. I wish everyone to know how lucky I feel that you are part of my life. 


\section{TABLE OF CONTENTS}

Chapter One: Introduction $\quad 1$

Chapter Two: Changing the Tide of Events 9

Agendas 9

$\begin{array}{ll}\text { Agenda Types } & 10\end{array}$

Models of Agenda Setting $\quad 13$

Policy Images $\quad 24$

$\begin{array}{ll}\text { Venues } & 26\end{array}$

Research on Venues $\quad 27$

Committees and Jurisdictions $\quad 30$

$\begin{array}{ll}\text { Summary } & 33\end{array}$

Chapter Three: Modern Environmentalism and the Property Rights Movement 34

The 1970s: The Beginning of Modern Environmentalism 25

The 1980s: Environmental Derailment, Rejuvenation, and Stagnation 38

Bush's Promise $\quad 40$

The 1990s: Green Hope? $\quad 42$

Green Slump $\quad 43$

The Environmental Justice Movement $\quad 44$

Environmentalism Today: Strategies 46

The Emergence of Property Rights $\quad 50$

Regulation's Frustration $\quad 50$

State and Local Regulation $\quad 53$

Igniting Antagonism $\quad 56$

The Industrial Lobby $\quad 57$

$\begin{array}{ll}\text { The Sagebrush Rebellion } & 57\end{array}$

The Wise Use Movement $\quad 60$

Wise Use Adherents $\quad 61$

Wise Use Support $\quad 64$

Defending Liberty $\quad 66$

$\begin{array}{ll}\text { Takings } & 67\end{array}$

Regulatory Takings $\quad 69$

$\begin{array}{ll}\text { Judicial Resolve } & 72\end{array}$

Chapter Four: Tracking the Property Issue in Congress 84

Legislative Resolve $\quad 85$

Property Rights Legislation $\quad 86$

Federal Takings Legislation $\quad 90$

$\begin{array}{ll}\text { Methods } & 97\end{array}$

$\begin{array}{ll}\text { Property's Salience } & 100\end{array}$ 
What's in a Property Hearing 102

Testing for Mobilization 106

$\begin{array}{ll}\text { Participating in the Mobilization } & 110\end{array}$

Jurisdictional Control 113

Participation in Committees 119

Nonlegislative Hearings and Committee Jurisdictions 125

$\begin{array}{ll}\text { Discussion } & 131\end{array}$

Chapter Five: States Move on Property Rights 134

Interviews 134

$\begin{array}{ll}\text { The Road to the States } & 137\end{array}$

The Court's Deferment 141

$\begin{array}{lr}\text { Congressional Inaction } & 142\end{array}$

Political Division $\quad 143$

Disorganization $\quad 144$

Resource Disparity $\quad 146$

$\begin{array}{ll}\text { State Takings Legislation } & 147\end{array}$

A Closer Look at State Action $\quad 152$

Strategy or Inevitability? 153

A Case for Sympathy or Group Pressure? 155

Political Strength and Public Influence 156

Legislative Influence $\quad 157$

Lobbying 158

$\begin{array}{ll}\text { Conclusion } & 159\end{array}$

$\begin{array}{ll}\text { Chapter Six: Conclusions } & 160\end{array}$

$\begin{array}{ll}\text { Closing } & 164\end{array}$

$\begin{array}{ll}\text { References } & 166\end{array}$

Appendix 1: Introduced Federal Property Rights Legislation, 1977 - 1998

Appendix 2: Interview Protocol 


\section{List of Tables}

Table 1: Number of Property Hearings by Topic, 1959 - 1995.

Table 2: Number of Property Hearings by Congressional Venue, 1959 - 1995.114

Table 3: Nature of Witnesses in Property Hearings by Congressional

Venues, 1959 -1995.

Table 4: Congressional Testimony on Property before House Environmental Committees versus Testimony before House Property Rights Committees, 1959 - 1995.

Table 5: Congressional Testimony on Property before Senate Environmental Committees versus Testimony before Senate Property Rights Committees, 1959 - 1995.

Table 6: A Property Rights Policy Timeline by Venue 137

Table 7: State Takings Legislation by Type 147

\section{List of Figures}

Figure 1: Percentage of Property Hearings by Chamber, 1959 - 1995. Figure 2: Proportion of Property Hearings by Topic, 1959 - 1995.

Figure 3: Proportion of Property Hearings by Tone, 1959 - 1995.

Figure 4: Type of Witnesses at Property Hearings, 1959 - 1995.

Figure 5: Property Hearings by House Committee Type, 1959 - 1995.

Figure 6: Property Hearings by Senate Committee Type, 1959 - 1995.

Figure 7: Nature of Witnesses in Property Hearings Held by House

Environmental Committees, 1959 - 1995.

Figure 8: Nature of Witnesses in Property Hearings Held by Senate

Environmental Committees, 1959 - 1995.

123

Figure 9: Map of Property Rights Legislation by State, 1998 


\section{CHAPTER ONE}

\section{Introduction}

The right to own property is a fundamental value in the United States, and the rights of the property owner are considered paramount (Sax 1971; Epstein 1985). That is, individuals have the right to use and dispose of their land in any manner they see fit. However, government reserves the right to overstep private property rights in certain cases. For instance, the government may exercise its police power to interfere with an individual's rights when that individual's use of the property creates a public nuisance (i.e., threatens the public safety and welfare, and violates the rights of others). The government does not have to compensate the person who causes a nuisance because the individual has no right to create a nuisance to begin with. Also, the government's power of eminent domain allows the government to seize the property of an individual wherein title of land passes from the owner to the government. In such cases, government is legally required to compensate the individual for the property. This important legal doctrine is embedded in the Fifth Amendment to the U.S. Constitution. The Takings Clause, as it is referred to, ensures that "no private property be taken for public use, without just compensation."

The Takings Clause was extended to the states and their local subdivisions by the Fourteenth Amendment to the U.S. Constitution. The Due Process Clause of the Fourteenth Amendment states, "nor shall any State deprive any person of life, liberty, or property, without due process of law." From these two legal doctrines, individuals have begun to argue against a new type of governmental taking, referred to as a regulatory taking. A regulatory taking occurs 
whenever there has been a diminution in the market value of land caused by either a new law or regulation, or a governmental action under an existing law, such as the Endangered Species Act (Fellows 1996).

Since the mid 1980s, many Americans have faced increased governmental regulations on property use at the federal and local levels. Whether the regulations are designed to protect the environment, to place restrictions on the use of urban land (e.g., zoning laws and growth management acts), to preserve historical sites, or to accomplish some other social goal, individual property owners are often left bearing a large proportion of the cost of the public good without compensation from the government. ${ }^{1}$ These incidents appear to contradict the Takings Clause, which was included in the Constitution to avoid the disproportionate placement of public burdens upon a single property owner (Kmiec 1997). Since 1991, twenty states have acted to resolve this conflict and have adopted property rights legislation to protect their individual property owners from being forced to carry a disproportional burden of a public good. ${ }^{2}$ This type of legislation is also referred to as takings legislation.

There are two general categories of takings legislation. Most are what are referred to as assessment statutes. These statutes typically require that government agencies "assess" whether

\footnotetext{
${ }^{1}$ For specific cases of government abuse of landowners see, for example, William Michael Treanor, The Armstrong Principle, the Narratives of Takings, and Compensation Statutes. William and Mary Law Review, March 1997 at 1151; Rick Henderson, Preservation Acts: The Property Rights Movement Moves Out of the Shadows. Reason Magazine, 1994; and, Jacqueline Switzer, Green Backlash, 1997. Stories found in these readings are often considered to be the real impetus behind the property rights movement.

${ }^{2}$ Washington enacted the first state takings legislation in 1991, only to be later rejected by a 3-2 margin in a public vote on a 1995 ballot referendum. Arizona and Delaware enacted takings legislation in 1992, although Arizona's bill was later rejected by a 60/40 margin in a public vote on 1994 ballot referendum. Indiana and Utah enacted takings legislation in 1993. Idaho, Mississippi, Missouri, Tennessee, Utah, and West Virginia enacted takings legislation in 1994. Arizona, Florida, Idaho, Kansas, Louisiana, Mississippi, Montana, North Dakota, Texas, Virginia, and Wyoming enacted takings legislation in 1995. Maine and Michigan enacted takings legislation in 1996. Idaho enacted takings legislation in 1998.
} 
their actions would constitute a taking under current judicial standards, and if so, refrain from the regulation or pay just compensation. Also included in this category are the Attorney General (AG) review bills. These bills normally require the Attorney General to set up a process for state and local agencies to evaluate proposed regulations for constitutional takings implications. The second category of takings legislation is generally referred to as compensation statutes. These laws require government to compensate property owners when regulations decrease the value of their property beyond a certain point.

Although the state legislatures have recently become involved, the traditional venue for the regulatory takings issue has been the courts. The U.S. Supreme Court's role dates back to its ruling in the case of Pennsylvania Coal v. Mahon \{260 U.S. 393 (1922)\}. More recently, the Supreme Court has ruled in two major property rights cases: Lucas v. South Carolina Coastal Commission $\{112$ S. Ct. 2886 (1992)\} and Dolan v. City of Tigard \{114 S. Ct. 2309 (1994)\}. Except when the government exercises its power of eminent domain and physically invades one's property, and in the very narrow case when a government regulation deprives an owner of all "economically viable" use of the land, the U.S. Supreme Court has failed to define when a governmental regulation constitutes a taking. Instead of offering clear guidance, the Court has based its rulings on vague decrees, such as the infamous "too far" edict $\{260$ U.S. 393 (1922)\}, and offered only indefinite formulas to determine when compensable takings occur \{438 U.S. $104(1978)\}$

The federal government began to protect private property rights when Ronald Reagan signed Executive Order 12630 in 1988 . Executive Order 12630 aimed to force federal agencies to consider the takings implications of their regulations and to budget money to pay for necessary 
takings (Lund 1995). ${ }^{3}$ Despite the objectives of Executive Order 12630, it is limited in two ways. First, it applies only to executive departments and agencies, and not to state and local government regulatory agencies. Second, and more importantly, the Clinton administration is not enforcing the order (Lipford and Boudreaux 1995). The hope for future federal legislation protecting property rights seems futile given the fact that President Clinton has threatened to veto any federal property rights bill fearing these laws, particularly the compensation type, will make the implementation of many regulations too costly and burdensome (Treanor 1997). The 1990s has seen numerous property rights bills introduced into Congress aimed at protecting property owners, such as the Private Property Protection Act of $1995 .{ }^{4}$ Yet, no federal takings legislation has been passed to date, and the prospects remain unpromising for the federal protection of private property rights.

The lack of judicial guidance in determining the occurrence of a governmental taking and the unpromising prospects for the federal protection of private property rights indicates that no national governmental institution has dealt with this issue in a definite fashion. Instead, the issue has moved between seemingly interested and sincere venues, only to remain a very contentious public matter. On the other hand, states have responded to the issue by either proposing or adopting takings legislation. This scenario poses some interesting research questions.

- $\quad$ First, what has been happening in Congress concerning this issue, and why has it failed to pass substantive federal takings legislation?

This research describes the battle for agenda control in Congress concerning issues of property.

\footnotetext{
3 Many of the state's assessment type takings legislation is patterned after Executive Order 12630.

${ }^{4}$ H.R. $925,104^{\text {th }}$ Congress, $1^{\text {st }}$ Session.
} 
Specifically, it examines the Congressional committee hearings to discover the participants accessing the policymaking process, and the committees exercising jurisdictional control over the issue.

- Second, why did the proponents of takings legislation seek to move the issue to a larger venue beyond Congressional committees?

- Third, what tactics did the proponents of takings legislation use to capture the agenda regarding this issue at the state level?

By examining the behavior of the "property rights community", I want to determine whether there was a conscious effort to motivate state officials to act. Specifically, I hope to show that the property rights proponents sought to shift the venue in which this issue was being considered from the federal level to the state level. More specifically, I wish to document whether the property rights community attempted to define the issue in terms that garnered disparate support from grass-roots activists, conservative advocates, and industry backed interest groups in the effort of inducing state-level responses.

I am studying the regulatory takings issue because it provides an excellent case to study theoretical questions concerning agenda setting. The battle for agenda control regarding this issue includes identifiable groups and, hopefully, discernible strategies. Moreover, the regulatory takings issue allows me to examine an issue that has switched venues from the federal to state level. Indeed, examining this vertical shift of venues is an important aspect of my study. Most of the previous research on the vertical shift of venues has been couched in the policy innovation

\footnotetext{
${ }^{5}$ The term 'property rights community' is used interchangeably here with proponents of takings legislation, property rights proponents, and advocates of property rights. Throughout the dissertation, the term is meant to encompass all those parties in favor of takings legislation.
} 
literature (Walker 1969; Dye 1990; Boeckelman 1992). This literature contends that states act as "laboratories of democracy" experimenting with new ideas. Those experiments that succeed are then passed on to other states or to the federal government; those that fail do so with great cost (Gray 1994). In short, most of the previous research that addresses the vertical shift of venues is approached from a policy learning standpoint, rather than a political one.

My study examines the political importance of a vertical shift in venue. That is, a shift from one level of government to another level of government, or from Congress to the state legislature. My focus on venue shifting as a means of controlling the political agenda is not new. However, until now most studies that use venue shifting as an explanatory argument for gaining political momentum have focused on horizontal shifting (i.e., from congressional committee to congressional committee or from the federal courts to Congress). I argue that, given its limited success in Congress, the property rights community has taken the issue before the state legislatures. State adoption of property rights legislation provides evidence that the property rights community is capturing the state political agenda through the efforts of its well organized and cohesive coalition of groups to redefine the property rights issue and shift its arena of discourse to the state legislatures. This new angle of inquiry will provide a foundation for future agenda setting studies which are able to demonstrate a vertical shift in venues.

Also, I am studying the regulatory takings issue because the matter is timely. That is, since 1991 twenty states have adopted property rights legislation, and every other state (except Connecticut) has had property rights legislation proposed or has property rights legislation pending. It is important to understand this political battle given the human, ecological, and economic consequences at stake as a result of the property rights community's success in 
influencing, and in some cases drafting, ${ }^{6}$ current and future environmental laws. Along with the policy consequences, my study of the property rights community's challenge for control over the agenda in this policy area promises to contribute to the existing literature on agenda setting.

Another unique contribution is my analysis of the property rights community's challenge for control of the political agenda at the federal level. To date, scholars have relied upon interviews with leaders of groups within the property rights community and aggregate data (e.g., number of groups and members) to argue that the property rights community has infiltrated the policy making community and begun to influence policy (Switzer 1997; Brick 1995). This prior data gives no indication of the community's success in gaining agenda access or influence over policy. For a less biased assessment, I study the Congressional committee hearings concerning property for the participation of witnesses, the tone of the hearings, and the number of hearings held. This approach will provide sound empirical evidence of the property rights community's effect on shaping policy, and it will also give a clearer picture of when the property rights community made an impact on the scene.

I hope this study will be significant to both political scientists and anyone with an interest in environmental studies or property rights. Political scientists will find my focus on the vertical shift in venues and the role played by issue definition in agenda setting as an informative and unique contribution to the understanding of the policy process. Environmentalists should find my study interesting because I am telling their story, so to speak. My explanation of how their

\footnotetext{
${ }^{6}$ For example, Senator Slade Gorton's (R - Washington) proposed revisions of the Endangered Species Act were written by Wise Use groups, including the Endangered Species Reform Coalition and the Endangered Species Coordinating Council (Kilmer 1995).
} 
opponents have challenged for control of the agenda with respect to property rights may better enable the environmental movement to take the steps necessary to maintain control, or at least stymie future attacks.

The dissertation precedes as follows. Chapter 2 provides the theoretical basis upon which I will build my arguments. I focus attention on the contemporary thought on agenda setting, and the concepts of issue definition and venue shifting. Chapter 3 reviews the 'life cycle' of the environmental movement, and its counter movement, the property rights movement. It also traces the legal history of the regulatory takings issue as it has been addressed in the Supreme Court. In chapter 4 I begin establishing and supporting my argument concerning the passage of the issue from the federal level to the states. My goal in chapter 4 is to track the property issue as it is addressed in Congress. I examine the Congressional committee hearings on property issues to determine what happened in Congress, and come to some conclusions as to why Congress has failed to pass takings legislation. In chapter 5 I explore the property rights issue as it moves to the states. I examine the vertical shift of venues and its affect on the challenge for the political agenda through the actions of those closely involved in the conflict. My goal is to determine the agenda building tactics employed by the property rights community, which in turn were instrumental in achieving legislative success. I present the findings from data gathered through direct and telephone interviews with federal government actors and members of interest groups involved in the regulatory takings issue. This evidence will be used to determine the efforts of those involved in capturing the state governmental agenda. In conclusion, chapter 6 will review and discuss the findings of the previous chapters. 


\section{CHAPTER TWO}

\section{Changing the Tide of Events}

The following chapter reviews the prominent theories on agenda setting. I will pay special attention to the concepts of problem definition and venue shifting as a means of acquiring agenda status since these activities played a critical role with respect to the property rights issue. I will also formulate hypotheses based upon propositions from the literature that will serve as guides to my study. But first, I am able to make one predetermination at this point. That is, reaching agenda status on any level is never guaranteed.

\section{Agendas}

The agenda is "the list of subjects or problems to which government officials, and people outside government closely associated with those officials, are paying serious attention at any given time" (Kingdon 1995, p.3). Gaining agenda status is a primary objective of any group or interest supporting a specific issue, and rightfully so given the substantial stakes involved in gaining agenda status. Most importantly, those who build and control the political agenda play an instrumental role in structuring subsequent policy choices. This is no small reward given our pluralistic society in which interest groups compete for political influence (Truman 1951; Latham 1952; Becker 1983; Walker 1991). Yet, the benefits of agenda control extend beyond policy influence. Agenda control also brings social recognition and the validation of certain values and beliefs to the exclusion of others (Cobb and Elder 1983). That is to say that when government decides to consider an issue it serves to validate the problem and lend credibility to the views 
held by those pressing the issue, as well as legitimizing its authority to address the issue. In light of government's capacity to consider only some issues, this consideration functions to determine the winners and losers in a social and political sense. Consequently, interests realize both personal satisfaction and public endorsement when their concerns are granted agenda status by government officials. In short, the agenda control over a policy matter is an objective worthy of competition given the political and social benefits.

\section{Agenda Types}

Roger Cobb and Charles Elder distinguish two basic types of political agendas. The first, or systemic agenda, "consists of all issues that are commonly perceived by members of the political community as meriting public attention and as involving matters within the legitimate jurisdiction of existing governmental authority" (Cobb and Elder 1983, p.85). The systemic agenda is home to those concerns widely shared by the polity, and conditioned by the dominant norms and ideology of a community. Consequently, items on the systemic agenda are typically comprehensive and abstract concerns representing society's values. Moreover, the items on this agenda will not suggest the alternatives available nor the means of dealing with the issue. Items on the systemic agenda are often identified through public opinion polls based on a ranking of serious problems. For example, a 1992 Newsweek poll indicated that voters cared more about the economy / jobs (43\%), the deficit (21\%), and health care (19\%) than any other issues (Vig 1997).

Once an item reaches the systemic agenda there is no guarantee that policy makers will address the issue. A primary constraint on an issue's progression is the legitimacy of the group pushing the issue or the issue itself. Groups with poor status (e.g., low income and resources) and 
community standing (e.g., little political influence) find it more difficult to influence decision makers (Cobb and Ross 1997). Also, societal beliefs and values may deem an issue inappropriate for government action. For instance, by now there is agreement regarding the ill health and economic consequences of tobacco use. Yet given our high regard for individual liberty, few Americans would support government action making its use illegal.

The second type of political agenda, or institutional or governmental agenda, is "that set of items explicitly up for active and serious consideration of authoritative decision-makers" (Cobb and Elder 1983, p.86). Items that reach this agenda are prime for government action. That is, at this point policy alternatives are usually available and the problems are directly identified. Consequently, institutional agendas contain fewer items than the systemic agendas, and the items are more specific and concrete. An example of an item on the institutional agenda would be a state legislature's consideration of various forms of legislation aimed at protecting the property owner from government regulations that diminish property value - i.e., "takings legislation."

It is normally the case that an issue first reaches the systemic agenda before ascending to the governmental agenda, especially when the issue presents great social consequences. However, the governmental agenda may also be accessed when interested parties from both the executive and legislative branches of government and the private sector (e.g., interest groups, corporations) move items directly to the governmental agenda because they do not need broader public support (Ripley 1985), or when they fear the issue's expansion will arouse substantial opposition (Cobb, Ross, and Ross 1976). Another instance whereby an item may reach the institutional agenda directly is as a result of a crisis, such as the meltdown at the Three Mile Island nuclear power plant in 1979. The meltdown, which threatened a release of radioactive 
fuel, provided a launching pad for the consideration of alternative fuels in reaction to the apparent threat of nuclear energy. Crisis situations immediately put something on the governmental agenda, regardless of public debate regarding the proper definition of the crisis. Not all items on the governmental agenda receive serious attention from decision makers however. For instance, many bills introduced in the U.S. Congress have symbolic appeal for constituents, but are never considered in committees and consequently never reach the floor.

John Kingdon describes a third type of agenda, or the decision agenda. It contains "the list of subjects within the governmental agenda that are up for an active decision" (Kingdon 1995, p.202). In other words, items on Kingdon's decision agenda are the short list of items on Cobb and Elder's governmental agenda. For an item to be up for an 'active decision,' such as legislative enactment or presidential action, there must be a viable solution available for the decision makers to consider. Thus, only those problems that have a practical solution attached to them will be considered for government action. Paul Light's (1982) study of the president's agenda supports this claim by showing that an item with an 'available alternative' was one that rises on the agenda, crowding out equally worthy subjects that do not have viable solutions. Cohen, March, and Olsen (1972) agree that action is much more likely when a solution is available, and add that public attention to a problem without an attached solution is a losing battle. Indeed then, problems coupled with a workable solution have a greater chance of reaching the governmental agenda, and a far greater chance of reaching the decision agenda. Since my study is concerned with the active consideration of policies, I will primarily focus upon both the governmental and decision agenda.

As stated previously, there is no guarantee that an issue will reach agenda status at any of 
the three levels. The fact remains that in the political game policy makers attend to some issues and not others. I will show that the proponents of takings legislation manipulated the issue's image to ensure that the policy makers granted it agenda status. That is, they clearly identified the problem and advocated several viable solutions to what they deemed an important public policy matter. Chapter three will explain how the property rights problem is defined by the advocates for takings legislation, as well as discuss the judicial attempts to resolve the issue. Chapters four and five will discuss the federal and state legislative solutions that the property rights advocates have proposed to resolve the problem. It should be noted that once an item reaches one agenda its ascension to the next is not automatic and some issues remain stalled between agendas for long periods of time. Moreover, governments often refuse to consider any problem seriously that promises to incite large public opposition (Cobb, Ross, and Ross 1976). How then do issues access the agenda?

\section{Models of Agenda Setting}

Agenda setting, or agenda building, refers to the process by which demands of various groups in the population are translated into items vying for the serious attention of public officials. Agendas are rarely stable. Rather, they fluctuate as problems get placed on the agenda, remain for some time, and then fade away as new problems appear and dominate attention. This ebb and flow of agenda status is referred to as agenda change. Scholars try to explain this process over time and across policy types in the effort to understand the public policy process better. The following sections discuss in detail the existing literature on agenda setting.

E.E. Schattschneider (1960) was the first to assert that the key to gaining the advantage in 
a social conflict was to affect both the type and number of groups participating in the decision process and increase the number of institutions considering the problem. The idea is to expand the scope of the conflict in order to disturb the status quo and cause policy change. This strategy is generally referred to as issue expansion. Since its description, scholars have incorporated Schattschneider's theory in developing most models of agenda setting.

Cobb, Ross, and Ross (1976) offer three models of agenda building: mobilization, outside initiative, and inside initiative. The mobilization model describes a process whereby agenda building is initiated by political leaders who, after placing the item on the governmental agenda, try to promote the interest and support in the general public needed for the adoption of their issues. Thus, government officials attempt to expand the issue from the governmental agenda to the systemic agenda in the hopes of demonstrating its relevance to particular groups that may impede implementation and persuade them that the new program merits government action. The issue's expansion is the key strategy in the mobilization model.

Cobb, Ross, and Ross's outside initiative model describes a process of agenda building whereby a nongovernmental group specifies a problem and attempts to expand it sufficiently enough to, first, reach the systemic agenda and, finally, the governmental agenda. As with the mobilization model, issue expansion is the key. It is hoped that once the issue is extended to new groups it will create enough pressure on authorities to force serious consideration of the issue. In view of the regulatory takings issue, the outside initiative model may be applied to explain the property rights community's attempt to capture the governmental agenda. The community's members consist largely of nongovernmental actors that have tried to define the issue to include economic, civil rights, and constitutional themes. By defining the issue in these terms, the 
property rights community has been able to build a coalition of property rights advocates which, in turn, have pressured state policymakers to consider takings legislation.

Cobb, Ross, and Ross's inside initiative model describes an agenda building process whereby issue expansion does not play a major role. The policy idea originates within a government agency, or within a group that has easy and frequent access to policy makers. As with the mobilization model, the issue reaches the governmental agenda relatively easily because of the position of the initiating group. However, with the inside initiative model, the issue catalysts do not seek public support for the innovation nor try to place the issue on the systemic agenda. Instead, they try to pressure public officials to place the issue directly on the government agenda by soliciting the support of influential groups that can be important in the passage and implementation of the policy.

John Kingdon (1995) presents a model of agenda setting based upon the participants of policy communities and the processes that effect agendas: politics, policies, and problems. These three streams of processes develop and operate largely independently of one another. For instance, solutions are developed by policy communities (e.g., issue specialists from academia, interest groups, and committee and congressional staff) whether or not they respond to a problem. ${ }^{1}$ Kingdon refers to these unattached solutions as the 'primeval soup' from which feasible alternatives are selected and linked to problems. ${ }^{2}$ Also, a development in the political

\footnotetext{
${ }^{1}$ Kingdon's policy communities' is similar to Hugh Heclo's (1978) concept of 'issue networks' which describes the flow of ideas between people inside and outside of government, as well as Paul Sabatier and Hank Jenkins-Smith's (1993) notion of 'advocacy coalitions' which describes the actions of actors from public and private institutions to achieve their policy goals.

${ }^{2}$ For a similar discussion of how policies are generated and selected see Michael Cohen, James March, and Johan Olsen, “A Garbage Can Model of Organizational Choice,” Administrative Science Quarterly 17 (March 1972): 1-25.
} 
stream, such as a change in administration that heightens attention to new policy priorities and new perceptions to existing problems, may change whether or not the policy community is ready. Similarly, fluctuations in the 'national mood' or 'political climate' may serve to promote or restrain items from reaching the governmental agenda. For example, the Republican congressional victory of 1994 created the 'fertile ground' that enabled issues such as balancing the budget to rise on the governmental agenda quickly. Finally, problems may grab the attention of policy makers through indicators, focusing events, or feedback, thus, forcing them to consider the problem (Kingdon 1995). For instance, the Exxon Valdez oil spill in 1989 acted as a focusing event to the risks of oil transportation. Kingdon's 'problem' stream demonstrates that there are incidents that can aid in issue expansion and agenda building.

Kingdon's model illustrates that at critical times the separate streams come together to impact the agenda and policy change. A problem is recognized, a solution is available, the political climate is ripe for change, and the constraints (e.g., budget limitations or political receptivity) do not prohibit action. Kingdon refers to these moments of opportunity as policy windows. Policy windows are fleeting and often short lived occasions when events in the problems or political streams push some issues to the forefront of governmental attention. For instance the publicity over the spotted owl controversy in the late 1980s and early 1990s marked the opening of a policy window. The leaders within the property rights community sought to take advantage of this political opportunity to rally support from those with grievances against the government and the environmental movement. They bargained that the public would side with the loggers whose jobs appeared to be at stake, rather than an obscure bird, and capitalized on the discontent which enabled them to appear as compassionate and reasonable (Switzer 1997). 
Policy entrepreneurs are political actors that take it upon themselves to ensure that a problem gets considered and framed a certain way when policy windows open. Whether described as opportunists who take advantage of occasions when they can stir attention to their problem or push their policy ideas (Kingdon 1984; Polsby 1984; Majone 1988), as policy actors who promote policy ideas (Mintrom 1997), or as policy advocates that are willing to invest their resources (time, energy, reputation) in the hope of a future return (Kingdon 1995), policy entrepreneurs often play an instrumental role in articulating policy innovations onto government agendas. Their reward or motivation for participating may be a combination of several things: their honest concern about the problem, their pursuit of material incentives (e.g., keeping one's job or ensuring one's rights over their property), the promotion of their policy ideas, and their sheer pleasure in participating. Paula King (1988) and James Smith (1991) suggest that policy entrepreneurs develop strategies for presenting their ideas to others. That is, they attempt to shape the terms of discourse surrounding the policy idea in order to sell, or "broker," their idea to potential supporters successfully (Riker 1986; Kelman 1987; Mintrom 1997). At the same time, policy entrepreneurs define policy problems to assemble and maintain coalitions to support their policy innovations. These coalitions can prove valuable political resources during discussion of policy ideas (Eyestone 1978; Smith 1991). Whether they be an elected official, a lobbyist, or a concerned citizen, policy entrepreneurs play a major role in agenda setting primarily by pushing for one kind of problem definition over another.

Andrew McFarland (1991) argues that the study of agenda setting may be viewed as a corollary to the study of political cycles. Models of political change, or cycle theories, imply a cyclical pattern of action and reaction. For instance, David Truman's (1951) 'wave theory' of 
interest mobilization states that the mobilization of one interest (e.g., business) provokes a counter mobilization of related interests (e.g., labor). Thus, these waves of mobilization and counter mobilization create a cyclical pattern over time. Robert Salisbury (1969) utilized Truman's theory to illustrate his 'arrow theory' which reasons that interest group proliferation is positively correlated with the socio-economic diversification of society. Also, Salisbury explained group mobilization as being a reaction to 'disturbances' in the social system. Thus, he depicts the American political system as going through a cycle of rest, disturbance, and rest. Arthur Schlesinger's (1986) view of American politics has the system experiencing patterns of oscillation between periods of rapid progressive governmental action (public action) and periods of conservatism (private action). In their study of political attitudes, Herbert McClosky and John Zaller (1984) parallel Schlesinger's views. Beginning in the 1920s, the authors find thirty year attitudinal swings between moods of 'capitalism' and 'democratic values'. An interesting and relevant conclusion taken from their study is that reformers call upon popular, latent, democratic attitudes during one phase, while business groups call upon latent, anti-government, pro-market attitudes at a later phase. Seemingly, this describes the behavior of the environmentalists and the property rights community. As the environmentalists enjoyed legislative success over property matters, it justified governmental regulations with conservation, ecosystem and species protection, and quality of life arguments. In reaction to these regulations, the property rights community has framed the matter in economic, anti-government, and legal terms. Finally, Andrew McFarland (1991) argues for a cyclical pattern of American politics fueled by the creation of powerful subsystems backed by business interests, and then the inevitable reaction against them based on consumer protection, democratic egalitarianism, and other ideals. In sum, 
cycle theorists suggest that agenda change follows a pattern influenced by the changes in society. Therefore, as the actions of one group prompt a reaction from another group, the items reaching the systemic and governmental agenda are subject to change.

Baumgartner and Jones (1993) were undoubtedly influenced by cycle theorists when modeling their recent theory of agenda setting. In Agendas and Instability in American Politics, the authors present their 'dual mobilization' theory which describes agenda access as being achieved through 'waves of mobilization'. The first wave, or Downsian mobilization, is based upon Anthony Downs's ‘issue attention cycle' regarding the life cycle of an issue. In Downs's approach, there is a preproblem stage in which little attention is given to a problem, followed by a state of alarmed discovery and euphoria which generates a lot of attention. This heightened attention gives way to a realization of the costs of solving the problem and, finally, a gradual decline in public interest (Downs 1972). Baumgartner and Jones's Downsian mobilization emphasizes the events occurring during the euphoria stage. During this time, heightened public attention prompts government action to solve a problem. Consequently, government creates institutions to deal with the problem. As Downs suggests, once the institutions begin to work and the costs are revealed, the public attention that served to prompt government action inevitably fades away. Yet, the institutions created during the period of euphoria endure, and the institutional legacy remains active for years (Peters and Hogwood 1985; Baumgartner and Jones 1993).

Environmentalism in the US has gone through a cycle similar to that described by Downs. As public enthusiasm toward environmental issues grew in the 1960s and 1970s, government was called on to create institutions and pass legislation in order to protect the environment. 
Environmentalism was quickly pushed out of the spotlight as the governmental agenda became preoccupied with national concerns such as the energy crisis and the economic recession of the late 1970s and early 1980s. However, unlike Downs's prediction of an inevitable regression of public attention toward environmental issues, polls conducted throughout the years have indicated that the environment has remained on the systemic agenda. For instance, since the 1970s, Gallup polls show that the environment has been ranked as the most important problem by a steady four to five percent of respondents (Switzer 1994). Also, a 1991 Gallup poll reported that seventy-one percent of its respondents agreed with the assertion that environmental protection should be given priority even at the risk of curbing economic growth, while twentynine percent disagreed or had no opinion. In 1984, sixty-one percent agreed with the same assertion, while thirty-nine percent disagreed or expressed no opinion (Rosenbaum 1995). ${ }^{3}$ Finally, in 1995, political scientist Everett Ladd and former Public Opinion managing editor Karlyn Bowman concluded through studying public opinion surveys that the environment has become a "core value" to most Americans (Morin 1995).

This support for the environment has been politically crucial for the movement, counterbalancing the advantage enjoyed by the opposition in financial resources and government access (Rosenbaum 1995). Moreover, the widespread and longstanding support for environmental protection has enabled the institutional structure created during the late 1960s and 1970s to endure. Consequently, it has been working for the last three decades to enact and

\footnotetext{
${ }^{3}$ For other public opinion studies that show substantial and frequently growing public support for environmental protection see also: Riley E. Dunlap, "Trends in Public Opinion," in American Environmentalism, ed. Riley E. Dunlap and Angela G. Mertig, 89-116; and John M. Gillroy and Robert Y. Shapiro, "The Polls: Environmental Protection,” Public Opinion Quarterly 50, no. 2 (Summer 1986): 270-276.
} 
implement environmental policies. ${ }^{4}$ It is apparent that the institutional legacy as described by Baumgartner and Jones (1993) and Peters and Hogwood (1985) exists in regards to environmental policy.

This environmental support and institutional legacy may be working to do more than promote environmental policies. Recent research by Roger Cobb and Marc Ross (1997) suggests that opponents to policy change may scheme to deny the initiators of policy change agenda access. Strategies of agenda denial, as it is referred to, may range from the simple denial that a problem exists to legal and physical threats. In the case of regulatory takings, the environmental movement's strategy has aimed to dispute the facts of the issue, argue that the concerns are isolated incidents and do not apply to the general public, and raise fears within society that takings legislation will undo years of environmental laws and severely threaten the future health of the environment. Based on Cobb and Ross's (1997) propositions, the agenda denial strategies of the environmental movement may have contributed to the property rights community's failure to achieve legislative success in Congress, which in turn created the incentive to move the battle to the states.

Baumgartner and Jones's second wave of mobilization, or Schattschneider mobilization, may often be viewed as a reaction to the first. That is, the fear and criticism toward the policy consequences of the Downsian mobilization serve as the fuel for a counter mobilization. Baumgartner and Jones premise this idea upon the work of E. E. Schattschneider (1960) who, as stated previously, was the first to describe the efforts to increase the number of participants in the

\footnotetext{
${ }^{4}$ For a list of major laws on the environment, see Appendix 1 of Norman J. Vig and Michael E. Kraft, 1997, Environmental Policy in the 1990s: 3rd ed. Washington, DC: CQ Press.
} 
conflict and increase the number of institutions (venues) considering the problem in order to disrupt the status quo. Thus during a Schattschneider mobilization, opponents begin to question the policy choices in effect and seek to expand the issue beyond the existing policy making system. The goal of such activity is to destroy the institutional structure created during the Downsian mobilization, and that which impedes the opponent's policy goals (Baumgartner and Jones 1993).

Baumgartner and Jones demonstrated how policy change may result from the mobilization of adversaries in their study of the nuclear power, smoking and tobacco, and pesticides issues. They showed that as subsystems are created, new institutions are created that structure future policy making and the influence of outside groups. Moreover, they argued that the mobilization may act to destroy the institutional structure that biased one interest over another, thus facilitating policy change. These findings suggest that the mobilization of adversaries in the policy arena may act to abolish the institutional and group biases that previously prevented policy innovations from reaching the governmental agenda. Baumgartner and Jones refer to this process of policy change as punctuated equilibrium (Baumgartner and Jones 1993). The institutions created during the periods of mobilization remain for years until attention shifts again and institutional changes occur. Nonetheless, the policy outputs that policy entrepreneurs are able to push through during these periods of punctuated equilibrium have lasting importance.

The legislative successes of the environmental movement have not been celebrated by everyone. Instead, a formidable opposition to the movement has grown over the years propelled by the discontent toward regulatory takings (Marzulla 1995). In agenda setting language, the 
mobilization of the property rights community is a reaction to the policy consequences developing out of the environmental laws of the past three decades. I believe the property rights community has engaged in a Schattschneider mobilization by arguing against the economic burdens brought on by environmental regulations and framing the issue as an infringement on individual liberty and a violation of one's civil rights.

Baumgartner and Jones 'dual mobilization' theory suggests a cyclical pattern of political change in the United States much like that espoused in the cycle theories. However, they claim their depiction of a punctuated pattern, rather than a cyclical pattern, of policy change is more complete given the identification of an institutional legacy and its capacity to bring in fresh definitions of political issues. New issue definitions of familiar problems mean that the changes brought on by changes in the institutional structure are different from those that occurred before. Therefore, while the political mobilization of interests in American politics is a reaction to the existing political arrangements, it need not be related to the mobilizations of a generation before.

The review of the literature underscores the importance of issue expansion in agenda setting. In general, the previous models follow Schattschneider's lead in emphasizing the effects that an increase in participants and venues may have on agenda change. Cobb, Ross, and Ross's 'mobilization' model and 'outside intiative' model emphasize the utility of issue expansion in garnering support from new groups and moving the issue up on the systemic and governmental agenda. Kingdon's 'problems' stream illustrates the important role played by policy entrepreneurs to expand an issue by framing it in such a manner to solicit as much support as possible. My study of the regulatory takings issue follows Baumgartner and Jones's 'dual mobilization' model that gives great weight to issue expansion, particulary during 
Schattschneider mobilization when it is used to fuel the effort to destroy the institutional structure that obstructs the policy goals of an interest. To be sure, issue expansion is critical in most cases of agenda setting.

\section{Policy Images: “The power is in the definition...” - E. E. Schattschneider}

The process of issue expansion is complicated as groups compete for attention while expanding their issue, and also deal with the opposition forces that are trying to limit its expansion (Cobb, Ross, and Ross 1976). Groups overcome these obstacles by manipulating how an issue is understood and discussed, or its policy image (Baumgartner and Jones 1993). Problems are socially constructed and they arise from the meanings that people attach to the circumstances surrounding the problem. This enables numerous interpretations of the same problem, which are shaped not only upon facts, but also upon beliefs and values (Cobb and Elder 1983). Our beliefs and values determine what is to be taken as fact, what facts are considered relevant, and how those facts are interpreted. Thus, in the absence of a single, fixed definition, policy images vary as opposing interests attempt to frame the problem to further their objectives, while also suppressing the merit of competing definitions. It is argued that this competition over opposing policy images is an ingrained part of politics and a defining component of the struggle for agenda control (Stone 1989; Baumgartner and Jones 1993).

The struggle over a problem's definition has great consequences for its political standing and the design of policy solutions (Rochefort and Cobb 1994). Indeed, for Schattschneider (1960) a problem's definition was critical factor in a conflict's outcome. He believed that political success was achieved by controlling the expansion of an issue, and the primary method 
by which to either expand or limit an issue is through its definition. Previous studies have documented the defining process, and the implications for issue expansion. For instance, Cobb and Elder (1983) suggest that issue expansion is enhanced when the problem is: defined in ambiguous terms, defined as having great social significance, defined as having extended temporal relevance, defined in non-technical terms, and defined as lacking a clear precedent. Similarly, the definition of issues in procedural and narrow technical terms has been found to be a method of restricting the scope of a conflict (Nelkin 1975). Other authors demonstrate that it is advantageous to associate a new issue with popular and emotionally laden symbols. They argue that linking familiar and positive symbols with a new issue helps develop an initial favorable reaction in the mass public, and helps to justify public policy approaches to them (Edelman 1964, 1971; Baumgartner and Jones 1993). Evidence of this claim is found in Bosso's (1987) study of the pesticides issue which illustrated the success of the pesticide opponents in gaining agenda access by challenging the original symbol of agricultural progress with claims regarding the risks to human health.

Kingdon (1995) adds that the defining process has a direct bearing on how a problem is treated. He argues that the policy solution chosen to remedy the problem may be influenced by categorizing an issue as one type of problem, as opposed to another. This apparently holds particularly true in the case of many environmental issues. For instance, the protection of threatened and endangered species may be classified as an environmental issue or a land use issue. Treated as an environmental problem, government's solution has been the Endangered Species Act (ESA) which, among other things, includes provisions prohibiting property owners from using thier land in such a manner which destroys the habitat of an endangered species. On 
the other hand, treated as a land use issue, government may pass laws requiring the payment of compensation to land owners when endangered species are found on their property, and the value of their property is diminished as a result of the property owners compliance with the regulations within the ESA. In sum, organized interests, activists, and policy entrepreneurs may attempt to categorize, or frame, an issue in a manner which benefits their policy objectives.

In the spirit of Schattesneider's (1960, p.68) declaration, “...power is involved in the definition", I believe that by framing the issue as a civil rights and economic issue, the advocates of takings legislation have benefitted from the support of numerous groups (e.g., conservative groups, libertarian groups), citizens, and most importantly legislators. The property rights movement has successfully framed the issue so as to: 1) define it as a violation of civil rights, which in turn has rallied support from disparate groups for the adoption of takings legislation that protects property owners, and 2) highlight the detrimental economic consequences of intrusive government activity on private property owners. The result has been the enhancement of the property rights community's cohesion and strength. This conclusion fits with the arguments presented above concerning the influence of problem definition. Finally, with the support of this strong coalition, the property rights movement has succeeded in influencing state legislatures.

\section{Venues: “There's No Place Like Home”}

Schattschneider (1960) proposed that one of the basic strategies of any coalition is to manipulate the assignment of program responsibilities so that the governmental units that it controls have the most authority. In essence, Schattschneider is implying that shifting an issue's venue is an effective strategy of influencing policy. Baumgartner and Jones (1993, p.32) describe 
venues as "institutional locations where policy decisions are made." It is important to note that issues are subject to changing venues over time as competing coalitions seek to find a favorable setting in which to address their interests (Worsham 1998). For example, venue change is evident in US education policy which is traditionally a state and local government responsibility, but the federal government has played an increasingly important role over time. Also, the New Federalism of the Reagan years was a clear effort to impact policy by shifting the decision making location from the federal level to the states.

\section{Research on Venues}

Venue shifting has important policy implications. As Baumgartner and Jones (1993, p.31) point out, "each institutional venue is home to a different image of the same question." Congress, or some members, may look at the property rights issue as one of protection for the environment and natural resources. The Supreme Court may be more concerned with legal norms and its constitutional bearing. And, state legislatures may view the property rights issue as one of individual freedom and economic growth. These different perspectives lead to changes in policy when the venue shifts. Different venues present not only different images, but also favor particular groups (Baumgartner and Jones 1993; Worsham 1998). The choice of venue, then, often determines which groups will influence the policy outcomes, the manner in which the issue is framed, and the nature of the public policy produced. Stated simply, I argue that the property rights community has realized legislative success at the state level because state legislatures are more sympathetic to grass-roots, local, county, and state level interests. Or, in a more rational light, state level public officials may have supported the concerns of the property rights 
community in fear of the potential political backlash. This argument is supported by Michael Wasylik (1998), a representative of the interest group Defenders of Property Rights, who claims that the property rights community has gained legislative success at the state level because "the abuses are at the state level, the activists are state level, and many of the efforts of the property rights community are a reaction to state level bureaucrats and legislation.” Therefore, I contend that the property rights community has strived to shift the venue to the states for these reasons, and because of the community's lack of success at the federal level.

Policy specialization between the two levels of government (state/local and federal) lends importance to venue shifting. As a fundamental feature of American Federalism, policy specialization allows the different levels of government to pursue different policy priorities. For instance, research by Peterson (1981) and Peterson and Wong (1986) shows that state legislatures function to serve the economic interests of the state more so than any other institution. Also, their research shows that state and local governments are pushed toward the pursuit of policies that promote economic growth, whereas the federal government is more likely to pursue policies that redistribute benefits toward disadvantaged citizens. Their results indicate that state and local governments are more effective in pursuing developmental policies, while the federal government is more successful in pursuing redistributive policies. This argument is extended to contend that governments are more receptive to policy issues that fall within their speciality. Baumgartner and Jones (1993) find evidence of policy specialization through their study of the investment-consumption ratio of the different levels of government. Finding that different levels of government in the United States pursue different strategies of investment (investment or consumption), the scholars show that each level specializes. The implications of policy 
specialization for my study suggests that if the property rights community is successful in framing the property rights issue in economic terms it has a greater incentive to move the property rights battle to the states where receptive legislatures are more likely to enact property rights legislation.

In sum, the venue where an issue is facing serious consideration matters greatly. An institution's control over the proceedings may have a large impact on how the issue is framed and the types of groups influencing the decisionmaking process. I think that institutional control played a role in denying the property rights community agenda access, and thus legislative success, in Congress. Furthermore, failure to have sufficient influence over how the takings issue was framed in Congress prompted the property rights community to seek a more favorable venue in the states.

Previous studies have concentrated on the battle over the environmental agenda at the national level (Bosso 1997, Switzer 1997, Brick 1995). However, the recent enactment of property rights legislation in twenty states indicates that the property rights community is having legislative success at the state level, and thus have strategically focused their efforts on influencing state legislatures. This view is supported by Moffet's (1996) study of interest group behavior with respect to the regulatory takings issue. Moffet finds that ag/industry groups (members of the property rights community) view their influence as increasing in state legislatures since the 1994 Republican victories in Congress and the state legislatures. This increase is paralleled by a decreased influence felt by two-thirds of the state environmental groups and all of the state affiliates of national environmental groups. Moreover, Moffett's study reports that ag/industry groups planned on increasing their legislative efforts because of an 
increase in the number of legislators sympathetic to their concerns. Moffett's findings indicate that, from the property rights community's perspective, the state legislatures are the favorable venue for the property rights issue. This is where they feel they have governmental access and influence over policy. Thus, it reasons that this is where they are likely to successfully challenge for agenda control.

\section{Committees and Jurisdictions}

The organization of the legislative workload through a specialized committee structure is one of the important elements of how Congress works. Accordingly, this has been one of the most studied aspects of that institution (Fenno 1966, 1973; Shepsle 1978, 1979; Krehbiel, Shepsle, and Weingast 1987; Smith and Deering 1990; Krehbiel 1991; Hall 1993; Brown 1995, Worsham 1998). The conventional view of committee jurisdictions is that they are stable with distinct areas of specialization. This arrangement allows congressional leaders to claim jurisdiction over particular issue areas. Bills are referred to substantive committees according to their established jurisdictions, and committees are prohibited from initiating bill hearings where they lack jurisdiction (Fenno 1966, 1973; Froman 1967). Also, it may be argued, this arrangement obstructs significant change by conceding agenda control to those with an established interest in the continuation of the status quo.

Contemporary research into committee jurisdictions has revealed a more dynamic environment. Studies of the postreform-era Congress report the infrequency of jurisdictional monopolies and the increasing tendency for the jurisdictions to overlap (Jones and Strahan 1985; King 1992; Young and Cooper 1993; Jones, Baumgartner, and Talbert 1993, Worsham 1998). 
These and other studies verify, among other things, that the committee has significant influence over the content of the bills it considers. Thus, jurisdictional control is pivotal to the legislative process. With regards to the regulatory takings issue, I argue that jurisdictional control has played an important role in preventing the enactment of any federal takings legislation. The environmental committees exercising jurisdictional control property hearings have often refused to report takings bills out of the committee, thus effectively eliminated any real chance of a legislative solution. On the other hand, efforts by the property rights community to disrupt this jurisdictional monopoly may lead to legislative successes in the future.

Until recently, the literature on committee jurisdictions has not studied the effect nonlegislative hearings have on the legislative process. Talbert, Jones, and Baumgartner (1995) approach this area of research using congressional hearing data and personal interviews with members of congressional committee staff. They claim that congressional committee and subcommittee leaders use nonlegislative hearings to justify future claims for jurisdiction over legislation. Legislative hearings are those that consider bill referrals. Nonlegislative hearings include all the others, including oversight and investigative hearings. The scholars point out that nonlegislative hearings enable committee leaders to expand their jurisdictional boundaries since there are few restrictions on the topics that any subcommittee may investigate. In other words, by holding oversight and investigative hearings on a particular issue, the committee leaders and their staffs establish their records as experts in the area so that future legislation is more likely to be referred to them. This process often leads to the disruption of jurisdictional monopolies and changes in policy.

Congressional hearings have long been viewed as serving dual purposes. On the one 
hand, they may promote or "booster" an issue by focusing on the significance of the public problem and attempt to gain government support. On the other hand, they may be judgmental or "critical" of legislation and government policies (Griffith 1951). Aberbach (1990) finds that oversight hearings are usually the promotional type and are used to advocate policy alternatives. Also, Hinckley (1971) argues that hearings often enable rival interests the chance to participate in the legislative process, despite attempts by the committee chair to saturate the hearings with likeminded witnesses. One point is certain. Hearings are held with strategic intentions (Talbert, Jones, and Baumgartner 1995). This may be evidenced by the topics chosen to investigate and the type of witnesses invited to testify.

As discussed previously, definitions of policy issues change over time (Baumgartner and Jones 1991, 1993). Moreover, changes in these issue definitions are often closely related to change in Congress. That is, as issues are understood in new ways, different committees are able to claim new areas of jurisdiction. This phenomenon was evidenced in Christopher Bosso's (1987) study of the pesticide issue. He showed that as long as pesticides were considered as tools of farmers, the agricultural committees enjoyed exclusive jurisdiction over their regulation. Yet, as public concern grew toward the environmental aspects of the issue, a new set of committees became interested in the matter. Thus, the interaction of issue definition and jurisdictional change may often facilitate changes in policy outcomes (Talbert, Jones, and Baumgartner 1995).

In my dissertation I will determine whether nonlegislative hearings played a central role in issue definition, and therefore had any impact on the legislative fate of the property issue. More specifically, I will study to see whether nonlegislative hearings were used by committees to convince others that the property issue has several dimensions, and that they have jurisdictional 
claim to one or more of them. I expect to find that committees used nonlegislative hearings to redefine the property issue to include important aspects, such as property rights and compensation, which also favors their future jurisdictional claims.

\section{Summary}

In conclusion, the battle for agenda control over the property rights issue is being fought in Congress and the state legislatures. The concepts of issue expansion, problem definition, and venue control are important considerations in explaining how the property rights community is challenging the environmentalists for agenda control. My study of the property issue in Congress examines its congressional history and helps explain the property rights community's failure to achieve legislative success. This in turn helps to explain the venue shift to the states where legislative success has been realized. A major contribution of this study is its examination of the vertical shift in venues that has occurred and proven to be an effective strategy for the property rights community. 


\section{CHAPTER THREE}

\section{Modern Environmentalism and the Property Rights Movement}

Robert Nisbet said "When the history of the twentieth century is finally written, the single most important social movement of the period will be judged to be environmentalism." ${ }^{1}$ No doubt, there is evidence lending both support and contradiction to this statement. In short, supporters may argue that environmentalists have triumphed in many Earth-saving battles and fostered environmental sensibilities embraced to some degree by a vast majority of Americans. Conversely, nonbelievers may rebut by asserting that, despite the triumphs of environmentalists, they have been unable to produce a significant improvement in the country's environmental health. It is not my goal either to substantiate nor refute this claim. Rather, I offer this quote to express only that environmentalism has garnered a large deal of respect since its modern inception. It may be argued that, apart from its earth-saving triumphs, the significance of the environmental movement may be attributed to its role in creating a counter movement. Generally referred to as the property rights movement, this counter movement is composed of grass-roots activists, conservative advocates, and industry-backed interest groups. The property rights community has become influential in the policymaking process regarding property matters. In particular, the community has evolved into a major opponent against the environmentalists over the regulatory takings issue.

This chapter illustrates the co-evolution of the modern environmental movement and the

\footnotetext{
${ }^{1}$ Quoted by Lynton Caldwell, "Globalizing Environmentalism: Thresholds of a New Phase in International Relations," Society and Natural Resources, 4, p. 259.
} 
property rights movement. It explains the environmental movement's role in energizing the property rights movement by illustrating how the consequences of environmental achievements have fueled their antagonists' reactions. At the same time, it traces the rise of the property rights movement and describes the members of its community. The chapter will also highlight the legislative and legal triumphs of both movements and discuss their implications.

\section{The 1970s: The Beginning of the Modern Environmentalism}

Most observers credit the first Earth Day, April 22, 1970, as the beginning of modern environmentalism. However, this landmark event was merely a response to a series of events throughout the 1960s that brought environmental issues to the attention of the public, and eventually policymakers. Two literary events had a particularly significant impact on placing environmental issues on the systemic agenda. First, Rachel Carson published her 1962 book entitled Silent Spring which focused public attention on the harmful impact of chemicals and pesticides, particularly DDT, on the environment. Carson's study of the use of chemicals and pesticides redefined the issue as a serious threat to the natural and human environment, whereas before it was largely considered an agriculture and commercial issue. Second, Paul Ehrlich published his 1968 book entitled The Population Bomb which warned the world of the dangers of the exploding population. Ehrlich succeeded in raising public awareness to the issue of population growth by framing the issue as a threat to a sustainable planet. Two "ecocatastrophes" also heightened public awareness toward the environment. First, in January and February 1969, two oil spills off the coast of Santa Barbara, California seemed to disturb the American public like never before. The media captured the essence of the spills with images of 
birds soaked in gooey, black oil and pristine, white beaches soiled with globs of oil (Steinhart and Steinhart 1972). Second, in the summer of 1969, Cleveland's Cuyahoga river burst into flames after a sailor threw a cigarette into it. Television sets across America exposed the incredible spectacle of the river burning from an abundance of toxic wastes and pollutants that saturated the river. The Santa Barbara oil spills and the burning Cuyahoga river captured America's attention, even if for a brief period, and contributed to placing the environment onto the systemic agenda.

Events such as these triggered a new environmental conscious in America toward the health and fate of the earth's natural resources. As the concern spread, more and more people joined existing national environmental groups, such as the Sierra Club, the National Audubon Society, the Wilderness Society, the National Parks and Conservation Association, and the National Wildlife Federation (NWF). Moreover, between 1967 and 1971, many new environmental groups were formed such as the Environmental Defense Fund (EDF), Friends of the Earth, the Natural Resources Defense Council (NRDC), and Greenpeace USA. These groups, and a few other, have guided and defined American environmentalism over the past three decades.

By the late 1960s and early 1970s, the environment had become a hot political issue. Government officials from every political persuasion claimed to be in favor of protecting the environment. On January 1, 1970, President Nixon signed the National Environmental Policy Act (NEPA) which, among other things, required detailed environmental impact statements for all major federal actions and established the Council on Environmental Quality (CEQ) to advise the president and Congress on environmental matters (Vig and Kraft 1997). In addition, President 
Nixon heralded a national commitment to a healthier environment by stating that "the 1970s absolutely must be the years when America pays its debt to the past by reclaiming the purity of its air, its waters, and our living environment. It is literally now or never!" (Shabecoff 1993, p. 112).

The new environmental leadership took advantage of the environment's status on the systemic agenda to mobilize millions of concerned advocates. As evidence, a 1970 Gallup poll reported that 53 percent of Americans viewed reduction of air and water pollution as a national priority, up from 17 percent in 1965. Moreover, by the 1990s, over 80 percent of Americans considered themselves environmentalists (Dunlap 1995). This widespread public support was accompanied by the creation of new federal agencies, including the Environmental Protection Agency (EPA) in 1970 as an independent regulatory body for pollution control, a reformed Nuclear Regulatory Commission in 1975, and the Department of Energy in 1977. The widespread public concern for the environment also encouraged government to take assertive legislative action to prevent environmental degradation. Like never before, a new federal environmental policy agenda emerged as environmental issues found their way onto the governmental agenda. The political appeal of the environmental issues drove policymakers to support tough new measures readily, even when their full impact and costs where unknown. As a result, the decade of the 1970s saw many federal legislative victories for the environmental movement. Most notably, Congress passed the Clean Ar Act Amendments of 1970, the Federal Water Pollution Control Act Amendments and the Federal Environmental Pesticide Control Act of 1972, the Endangered Species Act of 1973, the Safe Drinking Water Act of 1974, the Toxic Substances Control Act and the Resource Conservation and Recovery Act of 1976, the Federal 
Water Pollution Control Act Amendments and the Surface Mining Control and Reclamation Act of 1977, and the National Energy Act of 1978.

During the 1970s, the environment enjoyed greater public awareness and the federal government was supportive of new laws aiming to resolve environmental concerns. In agenda setting language, the issue reached both the systemic agenda and the governmental agenda. Cycle theorists might explain the environmental movement and legislative successes during this time as a reaction to government's pro-industry and development policies which led to many of the environmental problems (Truman 1951; Schlesinger 1986; McFarland 1991). In this light, the environment's status on the governmental agenda would soon change as the American political cycle continues to react to the mobilizations of concerned interests.

\section{The 1980s: Environmental Derailment, Rejuvenation, and Stagnation}

The 1980s ushered in a new conservative, Republican agenda led by President Ronald Reagan - a self proclaimed "sagebrush rebel." Reagan led an administration predetermined toward deregulation and budget cuts for the EPA in the effort to make good on his campaign promise to get government off the back and out of the pockets of Americans (Mitchell 1984; Vig and Kraft 1997). As a result, much of the legislative success realized in the previous decade was obstructed by the Reagan administration policies effecting the environment (Short 1989). In addition, the reductions in staffing, research, and enforcement activities under the leadership of EPA administrator Anne Gorsuch and Interior Department secretary James Watt stymied a lot of the legislative and attitudinal progress that had been realized in the 1970s. In sum, the Reagan administration's policies toward the environment disrupted the pro-environmental cycle that 
characterized the federal government.

To the dislike of many conservative advocates, the events during the Reagan administration acted to revive public concern toward the environment that was previously in a slow decline because of a sluggish economy, high inflation, and international events such as the Iranian hostage crisis (Dunlap 1987; Harris 1989). Reagan's lax enforcement of pollution laws and pro-development resource policies created political issues around which national and grassroot environmental groups could organize. The public was once again disturbed by the health and environmental risks brought on by an industrial society and by the threats to ecological stability. Consequently, membership in environmental organizations grew rapidly, stimulating renewed environmental activism at all levels of government. For instance, between 1980 and 1990, the membership in the Wilderness Society increased 780 percent (approximately 350,000 in 1990), the membership in the Sierra Club increased 350 percent (approximately 630,000 in 1990), and the membership in the National Audubon Society increased 150 percent (approximately 600,000 in 1990). ${ }^{2}$ The revenues of national environmental groups increased as well during the 1980s. For instance, between 1980 and 1990, the operating budget for the Wilderness Society increased 1180 percent (approximately 17.7 million in 1990), the operating budget for the Sierra Club increased 421 percent (approximately 40 million in 1990), and the operating budget for the National Audubon Society increased 360 percent (approximately 36

\footnotetext{
${ }^{2}$ For a complete listing of the membership trends among selected national environmental groups between 1970 and 1995 see Table 3-1 in Christopher J. Bosso's "Seizing Back the Day: The Challenge to American Environmentalism in the 1990s," in Environmental Policy in the 1990s, eds. Norman J. Vig and Michael E. Kraft. 1997. Washington D.C.: Congressional Quarterly Press.
} 
million in 1990). ${ }^{3}$ The marked increase in revenues suggests that people were not just joining environmental groups as a sympathetic gesture toward their cause. Instead, there was an active and sincere conviction for the goals of the environmental organizations. Moreover, the increasing membership and revenues of the environmental organizations indicates that the environment was home on the systemic agenda.

In spite of the weak environmental leadership on the part of Reagan and some of his ideologically committed appointees, Congress did pass some major environmental laws during these years. Among Congress's most notable achievements during the 1980s were its strengthening of the Resource Conservation and Conservation Act in 1984, the Superfund Amendments and Reauthorization Act of 1986, the Safe Drinking Water Act of 1986, and the Clean Air Act of 1987. Therefore, it seems that despite the efforts of a popular president to limit the budgets and capacity of environmental institutions and programs, the achievements of the environmental movement as evidenced by the legislative successes of the 1980s could not be completely thwarted.

\section{Bush's Promise}

The environmental movement had renewed promise leading into the 1990s as it rode a new wave of environmental concern that spread throughout society and government evidenced by the growing memberships of environmental organizations and the passing of new environmental

\footnotetext{
${ }^{3}$ For a complete listing of the operating budgets of selected national environmental groups see Table 3-2 in Christopher J. Bosso's "Seizing Back the Day: The Challenge to American Environmentalism in the 1990s," in Environmental Policy in the 1990s, eds. Norman J. Vig and Michael E. Kraft. 1997. Washington D.C.: Congressional Quarterly Press.
} 
laws, as discussed in the previous section. The election of President George Bush in 1988 brought a man promising to be "the environmental president" into the White House (Bosso 1997). He, and Congress as well, responded to the rejuvenated and widespread public concern for the environment by eagerly attempting to adopt a more positive environmental policy agenda. Bush's agenda goals included, among other things, a new Clean Air Act, a program of "no net loss" of wetlands, a strict enforcement of toxic waste laws, and the positioning of the United States as the global leader in the battle to abate global warming (Holusha 1988). Bush's environmental resolve culminated in the passage of the 1990 Clean Air Act Amendments and the 1992 Energy Policy Act, which are arguably the two most important legislative achievements of his presidency (Switzer 1994; Vig 1997). It seems that during Bush's presidency the federal government was responding to the systemic agenda by acting upon the environmental concerns held by the public.

With respect to property rights, perhaps the most important event occurring during the Bush administration concerns wetlands. During his tenure as president, the EPA, under thenadministrator William Reilly, issued a new wetlands delineation manual in 1989. The new manual broadened the definition of "navigable waters" and redefined lands that held water for short periods of time each year as "wetlands." This change led to a doubling in the amount of land over which the federal government exercises control (from 100 to 200 million acres). More importantly, over 75 percent of the new "wetlands" are privately owned (Marzulla 1995). The ultimate consequence of the redefinition was the expansion of federal control over property rights under the Clean Water Act.

Despite his early environmental agenda, Bush spent his final years in office pushing for 
more regulatory relief. This effort was spearheaded Vice President Dan Quayle and the Council on Competitiveness whose function was to invite and respond to industry complaints of excessive regulation, to analyze the costs and benefits of regulation, and to hold up or rewrite any new regulations that were considered unnecessarily burdensome (Tiefer 1994). In short, the environmental movement realized few legislative achievements during Bush's tenure. By the end of 1991, the movement had endured twelve years of presidential leadership that worked toward reduced regulation.

\section{The 1990s: Green Hope?}

If president Bush signaled a renewed promise for the environmental movement, then the Clinton administration symbolized a faith restored. The election of President Bill Clinton and Vice President Al Gore in 1992 brought a sense of euphoria to the environmental movement. In addition to the strong environmental stance of the new Democratic platform, environmentalists were excited due to Gore's reputation as the Senate's leading environmentalist and his authorship of the best selling book Earth in the Balance in early 1992. Their expectations were satisfied by Clinton's decisive moves early in his first term. One of Clinton's first acts was to abolish Quayle's Council on Competitiveness and replace it with the Office of Environmental Protection (which was later folded into the Council for Environmental Quality) headed by Gore's protégé Kathleen McGinty. Clinton also issued executive orders requiring consideration of environmental justice and mandating pollution prevention and waste reduction throughout the federal government (Vig 1997).

Despite these and other innovations in environmental policy and administration, many 
argue that Clinton's environmental leadership has been weak at best (Wicker 1994; Dowie 1995). In explanation, some argue that the president has failed to communicate his environmental policies to the public (Jones 1995). Others argue that it was the Republican congressional victories of 1994 which returned a Republican majority to both congressional chambers and ushered in a new Republican leadership largely unsympathetic to most of the environmental legislation of the previous two decades (Rosenbaum 1998). The 1994 elections began what was to be many years of hostile and unproductive battles between the congressional critics of existing environmental legislation and environmentalists, their congressional allies, and the Clinton White House. The environmentalists were on the defensive like never before, and in the face of a Republican controlled Congress, Clinton was unable or unwilling to promote an aggressive environmental agenda. The 1996 national elections had little effect on Clinton's strategic position with Congress, and the White House maintained a passive stance on environmental matters.

\section{Green Slump}

Despite its renewed promise, the environmental movement experienced some setbacks during the early 1990s. The large national environmental organizations were failing to produce convincing results with the millions in revenues collected from their supporters. Explanations as to why this happened vary widely. Yet, Dowie (1995) points out that the decline in the organizations' effectiveness coincided with their professionalization and concurrent loss of passion within the ranks. Also, and likely in direct relation, the organizations' membership began to abandon them. For instance, between 1990 and 1995, the membership of the Wilderness 
Society decreased 11 percent (from 350,000 to 310,000), the membership of the Sierra Club decreased 10 percent (from 630,000 to 570,000), and the membership of the National Audubon Society decreased 5 percent (from 600,000 to 570,000 ).

As membership in the national organizations waned in the 1990s, public opinion polls indicated a decreasing concern for environmental protection. A 1988 Lou Harris poll found that 97 percent of Americans believed that more should be done to protect the environment; five years later the same question received an 82 percent response. This information could be interpreted to suggest that environmentalism was experiencing its inevitable demise, or what social historians refer to as the "natural decline" of all social movements. One could easily come to this conclusion except for the fact that the total contributions to all environmental organizations was increasing during the early 1990s. This suggests that people were beginning to express their environmental interests in different ways while developing new environmental objectives (Dowie 1995).

\section{The Environmental Justice Movement}

One significant environmental interest, which prior to the 1990s had been largely ignored by the mainstream environmental movement, concerns the unequal distribution of environmental risks, or "environmental justice" (Ringquist 1997). Incidences of environmental inequity have prompted charges of racial and class biases in environmental protection. The general argument is that minority neighborhoods suffer from worse air quality, worse water quality, more landfills, more sources of toxic pollution, more hazardous waste sites, and weaker enforcement of 
environmental regulations than wealthier neighborhoods with smaller minority populations. ${ }^{4}$ As a result, hundreds of advocacy groups have formed into what is generally referred to as the environmental justice movement to fight against the social and civil injustices taking place in their counties, cities, and communities. Although the environmental justice movement has been in existence for as long as the mainstream environmental movement, it has only recently begun to refer to itself as an "environmental" movement. The idea is that substandard housing, health care, and employment opportunities contribute as much to the low quality of life in poor and minority communities as does environmental pollution. Therefore, if the preeminent objective of environmental activism is the protection of the health of the entire environment, the environmental movement must view social and environmental justice as inseparable.

The environmental justice movement has aligned itself with the mainstream environmental movement in seeking both social and environmental justice. The association of movements was firmly established at the 1991 People of Color Leadership Summit on the Environment, held in Washington D.C. The Summit brought together environmental justice groups from every state in the country, as well as Puerto Rico, the Marshall Islands, Central America, and Canada, and leaders of most of the nation's mainstream environmental organizations to discuss issues of environmental justice. The official goal of the summit was to "reshape and redefine the American environmental movement" (Dowie 1995, p.151) The participants produced a statement of their goals titled the "Principles of Environmental Justice," which serves as the criteria for developing and evaluating government policies aimed at attaining

\footnotetext{
${ }^{4}$ For empirical evidence of environmental inequity see Evan Ringuist's "Environmental Justice: Normative Concerns and Empirical Evidence," p.231-254, in Environmental Policy in the 1990's, eds. Norman Vig and Michael Kraft, 1997.
} 
social and environmental justice. The principles call for, inter alia, guaranteeing the full representation of minority groups and the poor in the policymaking process, increased emphasis on pollution prevention, and individual participation in government and private decisions that

effect the well being of their community (Grossman 1994; Austin and Schill 1994). Many believe that the environmental justice movement has the potential to broaden the base of support for the traditional environmental movement, and possibly reinvigorate and refocus the forces of progressive politics behind environmental concerns (Paehlke 1989; Bullard 1993). Therefore, the environmental justice movement has the potential to extend the environment's stay on the systemic agenda and prolong the life cycle of the environmental movement.

\section{Environmentalism Today: Strategies}

The environmental movement today is still dominated by a handful of the largest national environmental groups that are all centered, if not headquartered in Washington D.C. They are staffed by highly professional and sometimes career environmental activists drawn from fields such as law and business administration. Over the years, the environmental movement's approach to protecting the environment may be summed up as the three L's - legislation, lobbying, and litigation. As a legislative strategy, the environmental movement sought the support of millions of voters regardless of political ideology, to rally behind environmental issues. Leaders of the environmental movement were then able to portray this new "green" voting block as a major influence in elections, thus prompting candidates to declare themselves environmentalists. New "environmental" candidates were elected from both parties, and a bipartisan legislative strategy became feasible. This strategy produced many new environmental 
laws and regulations, most notably in the years before the election of Ronald Reagan.

As a lobbying strategy, the environmental movement has maintained a federal focus. In 1969 there were only two registered environmental lobbyists in Washington D.C. Yet, there quickly became the necessity for a strong federal lobby to advocate their objectives. By 1985 , there were eighty-eight registered environmental lobbyists, and the environmental lobby was being proclaimed "the most effective lobby in Washington" (Mitchell, Mertig, Dunlap 1985, p. 228). The lobby grew to nearly one hundred representatives in 1990 as the strategy of the mainstream environmentalists increasingly shifted to the federal government. The environmental lobby has battled with Congress and its counter-lobby (primarily the industry lobby) over the contents of nearly every environmental law created over the last three decades. Through compromise and pragmatic reform, it has been a major influence over the formulation and adoption of environmental initiatives since 1969. However, as a result of the federal focus, Washington offices expanded and field offices either shrank or shut down. This move was possibly damaging to the environmental movement's character. That is, when the national organizations began to shift their talents and resources away from the mountains, rivers, forests, and communities they were formed to protect they began to lose their identity. As a result, each environmental organization lost its distinction and the environmental lobby as a whole became indistinguishable from the other two thousand or so lobbies in Washington (Dowie 1995).

The litigative strategy became employed when environmentalists realized that the government does not always enforce its own laws, and that citizens and interest groups must do so themselves through litigation to protect their legislative gains. In the 1970s, the dockets of the courts were stuffed with cases brought by the Environmental Defense Fund (EDF), the Natural 
Resource Defense Council (NRDC), the National Wildlife Federation (NWF), and the Sierra Club Legal Defense Fund (SCLDF) against violators of state and federal laws. In fact, many of the cases were brought against the federal government, which turned out to be the nation's leading environmental violator. The litigative strategy was successful as long as federal judges ruled in favor of the environment, which was frequently the case until the early 1980s. Yet, by 1992, more than half the 714 federal district, appellate, and supreme court justices in the country had been appointed by presidents Reagan and Bush. Most of these appointees were hostile to federal regulation and to the very notion that private citizens and their organizations should be able to redress policy grievances through the courts (Bork 1989). This led to the disruption of the environmental protection stronghold that the U.S. courts once provided the environmentalists. Also, as a result of this turnabout, U.S. courts in every district of the nation are increasingly requiring that health and safety regulations be cost-efficient. The courts are challenging federal agencies' authority to impose regulations, and ruling that plaintiffs that once had standing in their courts no longer do so. To put it succinctly, the courts are more and more inclined to throw out environmental and safety regulations and rule against environmental organizations in case after case (Dowie 1995).

The environmental movement's federal strategy to protect the environment has created a reliance on federal policy which has produced the weaknesses and vulnerability of the environmental movement (Dowie 1995; Bosso 1997). One criticism of the environment movement's federal strategy has been the alienation and undermining its own grassroots. As the mainstream environmental movement continued to pour attention and resources into the national lobbies, they increasingly lost touch with the local interests. As a result, local environmentalists 
sometimes saw the national groups pursuing an environmental agenda contrary to their needs. Moreover, the mainstream environment groups have done a particulary poor job at representing poor and minority interests, sparking heightened criticism by activists representing the emerging environmental justice movement (Hahn-Baker 1994). Another criticism of the environmental movement's past strategy has been the underestimation of the fury of their antagonists (i.e., the property rights community). The effect of this fury has been felt mostly at the local level where the property rights movement has been successful at co-opting many who might otherwise be natural allies of the environmentalists, especially the working-class voters (Bosso 1997).

Despite these criticisms, the modern environmental movement is still dominated and largely defined by the national organizations - a circumstance likely inspired by necessity more than anything else. Indeed, given our political system, it is more often an asset than not to have professional organizations that are able to go to battle with entrenched interests, pursue complex lawsuits in the federal courts, and provide financial and technical assistance to activists in an array of state and local venues. The perils the environmental movement faces as a result of its Washington focus, such as routinized issue advocacy and passive "checkbook membership," are tolerated by most members in return for the respect given to the movement's ideas in the halls of power (Hayes 1986).

In conclusion, the environmental movement has accomplished some significant achievements since its modern inception. As a result of its incredible growth in membership, skills, and financial resources, it has become an immensely large and wealthy network of environmental organizations. The environmental movement has played an invaluable role in educating the public and placing the environment on the political agenda where it has remained 
in varying degrees over the past three decades. Relying upon a federal strategy summarized by the three L's, the movement has accomplished many significant environmental victories in Congress and the courts. In the years to come, the value of the mainstream environmental organizations will be measured by how effectively they work with grassroots environmentalists toward expanding the traditional concept of environmentalism beyond resource conservation and species protection to include social and environmental justice (Greider 1992; Bullard 1993; Alston 1994).

\section{The Emergence of Property Rights}

The focus on property rights emerged from the Wise Use movement of the 1970s and 1980s to become a nationwide battle for freedom and individual rights (Yandle 1995; Marzulla 1995). The common sentiment shared by property rights activists is that regulation at the federal, state, and local level is increasingly impacting every aspect of property use (Ray and Guzzo 1993; Bast, Hill, and Rue 1994). Through its power to regulate, government increasingly takes the uses and benefits of property rather than condemn it and pay fair market value, thus violating the Fifth Amendment's guarantee that "nor shall private property be taken for public use, without just compensation." Thus, it is government's intrusion on property rights, largely in the name of protecting the environment, that has energized a new crusade to protect an individual's right to use and own all forms of interests in private property. This distinctly new environmental opposition is appropriately named the property rights movement.

\section{Regulation's Frustration}


Since the beginning of modern environmentalism, Congress has passed a myriad of environmental laws that, when taken as a whole, create a regulatory web covering virtually every aspect of property use and ownership. The increasing frustration experienced by people across the nation as they confronted the maze of regulations served to fuel the property rights movement. A look at a selection of major federal environmental laws and some of their provisions helps to convey this frustration.

The Clean Air Act (CAA), originally passed in 1970, amended in 1971, 1973, 1974, 1976,1977 , and significantly overhauled in 1990 , regulates the emission of pollutants into the atmosphere. ${ }^{5}$ It requires "major sources" of air pollution to obtain permits designating their allowable amount of emissions. Yet, since the regulations implementing the Clean Air Act of 1990 are still being drafted, there remains some ambiguity regarding the emission permits and the air quality requirements. The CAA is primarily implemented through state legislation that must be submitted for federal review in the form of a State Implementation Plan (SIP). In the case where a state fails to submit a satisfactory SIP, the federal government may impose a Federal Implementation Plan as well as subject the state to sanctions, such as a cut-off of highway construction funds or a limit on its allowable emissions. The CAA has affected the use of private property by its owners by creating regulations that influence the siting of industrial plants, commercial enterprises, and communities (Marzulla 1995).

The Clean Water Act (CWA) of 1972 regulates the discharge of pollutants into the nation's waterways. ${ }^{6}$ Similar to Clean Air, the Clean Water Act is implemented through state

\footnotetext{
542 U.S.C., Section 7401-7671q (1988 \& Supp. 1991).

${ }^{6} 33$ U.S.C., pgs.,401-26p, $441-54$ (1988).
} 
permitting programs called the National Pollution Discharge Elimination System (NPDES). Yet, there is no State Implementation Plan. Rather, the federal government determines the water quality standards the state must achieve. Therefore, just as the Clean Air Act restricts the uses of private land by requiring permits for new and expanding sources of air emissions, the Clean Water Act limits land use where there is any significant discharge of pollutants into the water. Section 404 of the Clean Water Act imposes a more direct impact on the rights of a property owner. This part of the Clean Water act granted the federal government authority over approximately 100 million acres of wetlands (this amount has nearly doubled since EPA's 1989 redefinition of "wetlands"). Under the EPA's current delineation, it is estimated that 75 percent of all wetlands in this country are privately owned. ${ }^{7}$ The private owner of a wetland is prohibited from altering the property, and will rarely receive any compensation from the government for so doing. Despite this intrusion of property rights, the property owner is still expected to pay property taxes on the land, and on the passing of the land to heirs, they may pay inheritance taxes based on the fair market value before the effects of the regulatory restriction (Ceplo 1995).

The Endangered Species Act (ESA) passed in 1973, and amended in 1976, 1977, 1978, 1980,1982 , and 1988, is a comprehensive piece of legislation aimed at preserving endangered species. ${ }^{8}$ Section 9 of the ESA bears the greatest consequences for property owners. It prohibits the "taking" of any species of animal or plant listed by the U.S. Fish and Wildlife Service (for terrestrial species) and National Marine Fisheries Service (for marine species) as endangered. The term "take" is defined in Section 3 as "to harass, harm, pursue, hunt, shoot, wound, kill, trap,

\footnotetext{
${ }^{7}$ See "Government, Keep Out," The Economist, July 2, 1994 at 26.

${ }^{8} 16$ U.S.C., p.1533-44 (1988).
} 
capture, collect, or to attempt to engage in any such conduct." ${ }^{99}$ The Fish and Wildlife Service (FWS) has defined "harm" and "harass" as any activity that adversely modifies habitat, therefore harming or injuring just one member of a listed species. ${ }^{10}$ Typically, it is the "harm and harass" provision that restricts property owners from using their land in cases involving endangered species.

As of July 1, 1994, the endangered species list included about 1,400 species and subspecies, including their habitat. Congress originally funded the FWS to buy sensitive habitat from private owners, and from 1966 to 1989 it purchased 735,396 acres of private land for habitat and other protective purposes (Dunlap 1988). Now unfunded, the Fish and Wildlife Service uses the ESA to engage in regulatory takings. According to its interpretation of the law, the FWS may prevent landowners from developing, harvesting timber, farming or any other activity in order to protect resident species on the land (Welch 1995). Thus, in the process of protecting species, the FWS locks up hundreds of thousands of acres of privately owned land. It should also be noted that a person found violating Section 9 of the ESA may be subject to a civil fine up to $\$ 25,000$ for each violation and a criminal penalty up to $\$ 50,000$ and/or imprisonment up to one year. ${ }^{11}$ Private landowners view this situation as nothing less than a violation of their rights under Fifth Amendment of the U.S. Constitution. More importantly, it has served as a rallying point for property rights advocates to mobilize against the burden of regulatory “overkill” (Marzulla 1995).

\footnotetext{
${ }^{9}$ Ibid. p. 1532

10 50 C.F.R., Section 17.3 (1992).

${ }^{11} 16$ U.S.C., p.1540 (1988).
} 


\section{State and local Regulation}

State environmental regulations add another layer of rules to the regulatory web covering the nation. They have contributed as much to the public frustration over the government enforced restrictions on land use as have the federal laws. In fact, state regulations may receive a greater share of contempt since they most directly touch people on a daily basis (Arrensen 1988; Lipford and Boudreaux 1995).

A number of federal statutes are written to create a minimum, or "floor," for state environmental protection in the effort to discourage a state from becoming a "pollution haven" where industry may flee to avoid environmental regulation. However, many federal laws allow the states a good deal of flexibility in determining how they will achieve compliance with the federal requirements. Also, states are allowed to go beyond the minimum federal requirements and adopt additional and more stringent regulations. For example, California, New York, and Colorado have adopted highly tailored air pollution regulations which cater to the state's own ecological, economic, and social needs (Marzulla 1995). ${ }^{12}$

States take the lead in a number of other environmental areas. State regulators oversee programs concerning mineland bonding and reclamation, the application of agricultural chemicals, and the protection of groundwater (Rabe 1997). Also, states often augment federal regulations when they want to regulate certain activities not covered in the federal law. This has been evidenced through state "mini-superfunds," requirements within State Environmental Protection Acts (SEPA), recycling laws, labeling rules, and "community right-to-know"

\footnotetext{
12 Federal regulations also guide programs for controlling water pollution, wetlands, nonmunicipal drinking water supplies, underground injection, and other hazardous waste treatment or disposal programs.
} 
requirements (Rosenbaum 1998). State and local governments are primarily responsible for zoning and land use restrictions on private property (Smith 1995). Furthermore, these land use regulations have expanded to include historic preservation, battlefield protection, scenic designations, setbacks along waterways and streams, farmland protection, establishment of "greenways," buffer zones, designation of parks and preserves, and restrictions on natural resource development. Finally, state and local governments often use incentive/disincentive policies, such as licensing and permitting schemes, and tax incentives, to encourage or discourage certain economic activities that affect the environment (Hoerner 1995).

When taken together, this array of federal, state, and local regulations forms a maze of rules and restrictions that apply to virtually every aspect of human activity. The regulations compound to create a sense of frustration amongst ordinary people as they become ignorant of the law, let alone how to comply with it. Indeed, there is little wonder why individuals often feel frustrated by their chances of protecting their rights against the enormous regulatory thicket. The frustration is amplified when individuals are asked to carry the burden of providing the public benefits of each environmental initiative without compensation. Indeed, this is no small request given the high cost of regulation. For instance, one study shows that environmental regulation costs rose from $\$ 41$ billion in 1973 to $\$ 126$ billion in 1993, stated in constant 1988 dollars (Hopkins 1991). And, these estimates do not account for the productivity drag or the value of lost consumption that accompanies higher prices generated by regulation. In the struggle over property rights, the burden has grown too large and the number affected has increased significantly enough to incite a formidable response. In other words, the existing regulatory overkill is responsible for creating the environment's major opponent - the property rights 
movement (Dowie 1995; Switzer 1997).

\section{Igniting Antagonism}

The environmental regulations of the 1970s serve as the first stimulants of the property rights movement. With the implementation of the new environmental laws, Americans faced regulators with the power to restrict the use of land, or "take" it, without compensation. As a result, many individual property owners felt they were being forced to bear the costs of implementing environmental policies, regardless of the public goal the laws where designed to serve. In other words, Americans felt they were being singled out to bear the burden of providing a public good. It is this infringement of constitutional rights - not opposition to environmental protection - that provoked the property rights movement (Marzulla 1995). Its conviction is based on the rationale that no motive, no matter how worthy its purpose, can justify violating the constitution $\{$ Pennsylvania Coal v. Mahon, 260 US 393, 416 (1922)\}. This includes the requirement to pay just compensation for takings. The antagonism between property rights activists and their environmental counterparts stems from the fact that environmentalists have supported the regulation that provides most of the reasoning for the current attack on property rights. Before discussing the contemporary property rights movement, I first want to provide an overview of the environmental opposition that has evolved since the beginning of modern environmentalism. The following sections will discuss the different varieties of environmental opposition, such as the industrial lobby, the sagebrush rebellion, and the wise use movement, to illustrate the diverse and dynamic nature the environmental opposition as it has grown to encompass the current focus on property rights. 


\section{The Industrial Lobby}

Early on, business interests were slow to react to the legislative initiatives proposed by the environmental movement. Historian Samuel Hayes (1987, p.307) observes that, initially the environmental movement "was looked on with fascination, but as its influence increased in the late 1960 s and early 1970s, the perception turned to incredulity and fright." That is, industry groups came to realize their stake in the environmental debate because they are usually the parties responsible for picking up the costs of compliance with most statutes and bills. One EPA study of the costs of providing a clean environment estimated an increase from $\$ 26$ billion in 1972 to $\$ 160$ billion in 2000 (expressed in 1986 dollars). Moreover, business would be responsible for 60 percent of the direct costs of public and private pollution control activities (Carlin, Scodari, Garner 1992). Because the stakes are so high, the industrial lobby, consisting mainly of the extractive resource industries, the chemical manufacturers, the nuclear power industry, and the automakers, has incentive to mobilize their resources and political expertise in direct opposition to the mainstream environmental agenda. They have employed a three-part strategy to fighting environmentalism. The first part is to lobby against any legislation that restricts production; the second part is to weaken any legislation that could not be defeated; and the third part is to thwart the implementation of environmental regulations (Mann 1990).

\section{The Sagebrush Rebellion}

While Congress was passing environmental laws with undetermined consequences during the 1970s, the actions taken by President Carter regarding public lands elicited an immediate 
response from the property rights community. With the support of Interior Secretary Cecil Andrus, Carter converted millions of acres of Bureau of Land Management (BLM) lands into federal wilderness areas, national parks, and wildlife refuges. Carter more than doubled the size of the National Wildlife Refuge System and added five million miles of rivers to the National Wild and Scenic River System (a fourfold increase in size in just four years). This effort to move public lands to the more permanent status of parks and refuges reduced the likelihood of conversion to private ownership. Consequently, western interests (e.g., cattlemen and miners) and politicians (particulary in Nevada, where the federal government administers 87 percent of the land) were outraged at what they considered to be an intrusion of federal government policy and an infringement of basic rights (Marzulla 1995). As greater attention was given to the issue, the national media dubbed the growing antagonism the "Sagebrush Rebellion."

The Sagebrush Rebellion was founded on the principle that the federal government had a trust obligation to dispose of public lands. Throughout the western states, from Nevada to Utah, Wyoming, and Montana, people were growing hostile toward the federal government's opposition to resource development in their region. Large landowners and leaseholders throughout the west determined that the only way to gain control of the land and its resources was to deed federal land over to the states and then have the states sell it off (cheaply of course) to private interests (Dowie 1995). This approach to resource management promised huge profits for the private owners of western acreage. It is estimated that western states contain 15 billion barrels of oil and 100 trillion cubic feet of natural gas, produce 40 percent of the nation's coal, hold enormous reserves of metals, and yield great productivity in the cattle and timber industries (Salisbury 1981). Unfortunately, the one resource western states found themselves lacking was 
people. With less than 5 percent of the nation's population, Westerners were at a disadvantage in Congress where members of more populous and urban states viewed the west as a wilderness playground that must be preserved - despite threats to the economy and employment.

People dependent upon federal land for their livelihoods, such as farmers, miners, loggers, ranchers, and "inholders" - those with property bordering or surrounded by federal land began to organize against the federal government and its policies that increasingly eroded their ability to earn a living. Trade associations representing each of these interests, such as the National Cattleman's Association, emerged to fight specific regulations. In addition, the creation of broader organizations in the mid 1970s, like the Center for the Defense of Free Enterprise (CDFE) and the National Inholders Association (now the American Land Rights Association) brought the groups together to form a common network.

By the early 1980s, the Sagebrush Rebellion demanded the attention of those environmental groups with a vested interest in public lands, such as the Sierra Club and the Wilderness Society (Chomski and Brooks 1980). Yet, the response from the mainstream environmental groups may have been short-sighted. Instead of addressing the ultimate victims of the federal land acquisitions (i.e., the small landowners and ranchers), they concentrated on shoring up their influence in the White House and Congress. As a result, they failed to acknowledge the grievances of their opposition and missed an opportunity to forge some cooperative allegiances with their antagonists (Dowie 1995). This misjudgement would come back to haunt them as the "Sagebrush Rebels" eventually mobilized into a much larger rebellion against the federal government and the environmental movement. The much larger environmental opposition came to be known as the "Wise Use" movement. 


\section{The Wise Use Movement}

The wise use movement takes its name from the philosophy of the American conservationist Gilford Pinchot. As founder of the Society of American Foresters and the first chief of he United States Forest Service, Pinchot is quoted as saying, "Conservation means the wise use of the earth and its resources for the lasting good of men" (Pinchot 1947, p.505). Little did he know that his philosophy of sustainable management and multiple use of natural resources would provide the philosophical underpinnings for a large and focused effort to oppose environmentalism. Yet, that is precisely what happened thanks in large part to the efforts of two individuals who are widely viewed as the founding fathers of the movement - Ron Arnold and Alan Gottlieb. Ron Arnold, a former Sierra Club member who now serves as the executive director of the Center for the Defense of Free Enterprise (CDFE), is an irrefutable adversary of the environmental movement, whose aim, in his own words, is to "destroy the environmental movement once and for all!" (Dowie 1995, p.93). Alan Gottlieb, a conservative fundraiser, teamed with Arnold to launch the new opposition movement after a Multiple Use Strategy Conference sponsored by the CDFE in August, 1988.

The important issues to the Wise Use movement are identified in Arnold and Gottleib's original 1989 mission statement entitled, The Wise Use Agenda. The statement consists of twenty-five goals for its members to work toward, including major alterations in the Endangered Species Act (ESA), such as excluding "non-adaptive species such as the California Condor and endemic species lacking the vigor to spread in range"; the opening up of most public lands for mineral and energy production and off-road vehicle use; giving the job of providing concessions 
in national parks to private firms with "expertise in people moving such as Walt Disney"; and making it a felony for any national forester to let a natural forest fire burn usable timber. Under the Agenda, old-growth timber would be immediately subject to logging, and private property rights would be protected by eliminating restrictions on development (Switzer 1997; Gottleib 1989).

\section{Wise Use Adherents}

Because its theoretical base is applicable to so many diverse interests, the nature of the Wise Use opposition is much broader than that of the environmental opposition discussed earlier. Whereas the industrial lobby was concerned with the fiscal consequences of environmental legislation and the sagebrush rebellion was concerned with the land use policies of the western states, the Wise Use movement is concerned with environmental initiatives that aim to protect the environment from the people, instead of for the people. As a result, the Wise Use movement consists of several "umbrella" organizations to which a diverse set of interest groups belong. Some of the major umbrella groups associated with Wise Use are the Alliance for America, the Blue Ribbon Coalition (BRC), the Western States Public Lands Coalition, and the before mentioned Center for the Defense of Free Enterprise (CDFE).

There is some overlap in membership among the groups, yet each appeals to a somewhat different clientele and has a slightly different agenda. The Alliance for America represents a broad coalition of small, mostly local groups, who rely on the alliance for information and view it as a focal point for their lobbying efforts in Washington, D.C. Each year the alliance stages a "Fly In for Freedom," which brings in several hundred local activists to the capital to lobby 
Congress and stage media-friendly rallies to further advance their agenda before the public (Alliance for America 1998). The membership of the Blue Ribbon Coalition is almost exclusively outdoor recreationists who are dedicated "to the preservation of all forms of off-road recreation in an environmentally responsible manner" (Switzer 1997, p. 93). The coalition uses its monthly publication entitled the Blue Ribbon Magazine, to coordinate lobbying efforts by bringing notice to its subscribers of key bills and regulations that affect its members at the state and federal level. The Western States Public Lands Coalition created the group called People for the West! to represent the mining industry's interests in light of bipartisan congressional attempts to revise the 1872 Mining laws (Byrnes 1992). The organization is active in lobbying against legislation that prohibits or restricts the private use of public lands. Finally, the Center for the Defense of Free Enterprise (CDFE) serves as the ideological source of much of the Wise Use literature. Referred to by many as a conservative think tank, the CDFE is responsible for disseminating much of the theoretical reason for the movement. By its own admission, the center caters to the average American so that "those who understand and value free enterprise may contribute to the defense and promotion of the economic system that made America a prosperous nation."13

These national parent organizations are the workhorses of the Wise Use movement as they disseminate information to its members and represent their interests in Congress. Together, they span the nation and bring together a very diverse network of interests. More importantly, with respect to my study, these national organizations challenge the environmental movement for control over the systemic agenda by increasing the public's awareness toward the issue of state

\footnotetext{
13 Taken from a Center for the Defense of Free Enterprise membership brochure.
} 
and federal land use policy. And, since much of the federal governments land use policies are crafted in the guise of environmental protection laws (see previous sections), the Wise Use groups have attempted to access the governmental agenda in the effort to influence agenda change in their favor (see Chapter Five for coverage of this issue in Congress).

If the umbrella organizations are the workhorses of the Wise Use movement, then its spirit can be found in the hundreds of grassroots groups throughout the country. These state and local groups all adhere to the Wise Use philosophy to some degree, but many have virtually no interaction with the national movement except to receive the umbrella group's publication. A good example of a small organization within the Wise Use movement is the California Desert Coalition (CDC). The CDC organized in 1986 to fight against the proposed California Desert Protection Act that planned to place 8 million acres of desert lands in the National Wilderness Preservation System, including 1.5 million acres considered by CDC members to be essential recreational and resource lands (Switzer 1997). The Desert Act eventually passed through Congress and was signed by president Clinton. Yet, through fierce lobbying and congressional testimonies, the CDC successfully stalled action on the legislation for nearly ten years. ${ }^{14}$

Another exemplary group is the Shasta Alliance for Resources and Environment (SHARE). The Greater Redding, California, Chamber of Commerce created SHARE in 1986 as an independent committee to focus on resource management policies of northern California (Alliance for Environment and Resources 1998). This small, local organization provides an invaluable service to its members by alerting them to current legislative events or issues. One benefit of being a product of the area Chamber of Commerce is that the alliance is able to utilize

${ }^{14}$ Taken from "The War is Not Over," Desert News Letter. 1995, vol.8, no.1:7. 
the Chamber's resources (e.g., office space, administrative services, facsimile machines) to augment their capacity to remain effective. One commonality of the smaller groups is that they often organize around a specific issue, or that their interests rarely extend out of the region. Moreover, these groups typically raise their own revenues through membership dues and directmail appeals.

The adherents of the Wise Use philosophy include industry leaders, real estate developers, timber organizations, farmers, hunters, fishermen, off-road bikers, four-wheel enthusiasts, and many others (Kriz 1993; Marzulla 1995). Its diverse membership has contributed to the growth of a powerful and numerically large movement, at least it gives that impression. Members of the movement claim its membership to be in the millions (Dowie 1995). Environmentalists argue that the membership of the Wise Use movement is exaggerated since it includes members of groups which are merely affiliated with one of the umbrella organizations, and therefore not verifiable participants (Snider 1993). One impartial observer estimates that there are probably fewer than 100,000 activists involved in the Wise Use movement (Helvarg 1994). Regardless of this debate, by condensing the diverse groups into a single entity it is easier to study the political struggle between the environmentalists and the property rights advocates, which include the Wise Use adherents and former sagebrush rebels.

\section{Wise Use Support}

Fueling the Wise Use movement's momentum is the support it receives from its adherents. Most of the financial support for the Wise Use groups comes from large corporations in the resource extraction industry, such as Exxon, Louisiana Pacific, and Boise Cascade. Also, 
large companies like Champion Paper and MCI fund foundations, which in turn support groups like the Environmental Conservation Organization and the National Wetlands Coalition (which assists developers seeking permission to drain wetlands for commercial real estate) (O' Keefe and Daley 1993).

The Wise Use movement garners a great deal of support from its populist message as well. The movement appeals to small landowners who are repeatedly told that the federal government and the environmentalists are conspiring to steal their land (Brick 1995). One response to this perceived threat is the "county movement." This Wise Use initiative calls for all control of public lands to be shifted from state and federal to county government (Lavelle 1995).

The Wise Use movement gets rhetorical and ideological support from the media through social commentators such as Rush Limbaugh and George Will. Individuals like these, however, spend more time trashing environmentalists than they do defending the ideas of Wise Use ideology. Every day on his nationwide radio broadcast, Limbaugh can be heard charging environmentalists with subverting the American way of life. For instance, he says, "With the collapse of Marxism, environmentalism has become the new refuge of socialist thinking," and "What better way to control someone's property than to subordinate private property rights to environmental concerns" (Limbaugh 1992, p.116). Ron Arnold would agree with Limbaugh's claims. Arnold believes that the environmental assault on private property has created grave economic and social consequences. For instance, he credits the assault for decreasing the gross domestic product by 6 percent annually. Also, Arnold claims that when environmental regulations force a factory to close down it creates changes in the behavior patterns in those reliant upon the factory. Consequently, Arnold suggests you see increases in domestic violence, 
child abuse, drug and alcohol abuse, and an overall disintegration of the community (O'Keefe and Daley 1993). Rhetoric such as this has contributed to the appeal of the Wise Use ideology and attracted an increasingly large, diverse membership by redefining the environmental issues in economic and civil rights terms. That is, I argue that by changing the image of the issue the Wise Use movement has mobilized its members in opposition to many environmental laws that concern property use and rights. In the words of David Helvarg, who spent three years studying Ron Arnold, Alan Gottlieb, and their followers, the Wise Use Movement is "a backlash...a large and well organized backlash" against environmentalism. ${ }^{15}$

\section{Defending Liberty}

In 1972, the Supreme Court noted "In fact, a fundamental interdependence exists between the personal right to liberty and the personal right to property. Neither would have meaning without the other." 16 The Property Rights movement takes this opinion as gospel, and views the environmental ethic as an attack on liberty (Helvarg 1994). Nancie Marzulla, president and founder of Defenders of Property Rights - a nonprofit, public interest legal foundation dedicated to the preservation of constitutionally guaranteed property rights, argues that "the property rights battle has now become a fight for freedom and individual rights, with property recognized as more than just land." ${ }^{17}$ The adherents to this relatively new opposition movement believe that environmentalism is based less on environmental protection and more on the untruth that people

\footnotetext{
15 Quoted in David Helvarg, The War Against the Greens. San Francisco: Sierra Books, 1994, p.137.

${ }^{16}$ Lynch v. Household Finance Corporation, 405 U.S. 538, 552 (1972).

17 Taken from Nancie Marzulla, "The Property Rights Movement: How It Began and Where It Is Headed," in Land Rights, ed. Bruce Yandle. Lanham, MD.: Rowman and Littlefield. 1995.
} 
should have only limited rights over their property, when it is deemed acceptable to government regulators. In addition, they view most environmental legislation to be illogically based on the notion that the world would be a better place without humans, and that environmentalists want to burden the individual for his/her activities that impact the environment (Knox 1993). For example, the Clean Water Act is designed to restore the biological and chemical integrity of our nation's waterways. In fact, it sets a goal of zero discharge into our nation's waterways. Clearly, practically all human activities, including taking a shower and using the restroom, involves the discharge of water into the nation's waterways.

From a property rights perspective, the impractical provisions written into environmental regulations such as the Clean Water Act denies the rights of property ownership. They alienate the majority of Americans by presupposing that government can do things better than people, thus fostering the property rights movement. Defenders of Property Rights assert that "the entire property rights movement is a reaction to government regulations as a whole, including environmental protection, historical protection, and the attitude that government could solve all problem. Its definitely a reaction." ${ }^{18}$ The property rights movement is founded on the recognition that the "better" way to achieve environmental protection involves a recognition of property rights and a cooperation between property owners, government officials, and environmentalists. The central idea is that exclusive ownership of property creates the only effective, long-term incentive to conserve resources and minimize pollution (Marzulla 1995).

\section{Takings}

18 Taken from a personal interview with Michael Wasylik of Defenders of Property Rights. June 19, 1998. 
Embedded in the Fifth Amendment of the U.S. Constitution is the phrase, "nor shall private property be taken for public use, without just compensation." This legal principle is referred to as the Takings Clause and protects the property owner from a governmental condemnation, or seizure, unless it is for a public use and the owner is paid "just compensation." The concept of just compensation is interpreted as the property's fair market value. The drafters of the Constitution were not against the taking of property for public purposes, but were opposed to having the property owner pay the costs of the public good. As the U.S. Supreme Court stated in Armstrong v. U.S., the Takings Clause of the Fifth Amendment was instituted "to bar government from forcing some people to bear the public burdens which, in all fairness and justice, should be borne by the public as a whole" $\{364$ U.S. 40 (1960) $\}$.

The constitutional guarantees of the Takings Clause were extended to the states by the Fourteenth's Amendment's Due Process Clause, which states, "nor shall any state deprive any person of life, liberty, or property, without the due process of law." With respect to public land use decisions, the "due process" requirements usually include the notification of governmental action and the opportunity for a formal hearing (Coyle 1993). The Due Process Clause protects individuals from arbitrary and unreasonable government action, but offers no guarantee that the property owner will retain unlimited rights to use the land.

Despite the constitutional guarantees written to protect the rights of the property owner, government has reserved the right to infringe upon private property rights in certain instances. Through its "police power," government has the right to interfere with private activity or the use of private property for the protection of public health, safety, and general welfare. The Constitution's Tenth Amendment provides the states with police powers, however, most of the 
states have entrusted this authority to local governments. With respect to land use, zoning and nuisance laws are the most common use of the police power. The Supreme Court has upheld the principle of zoning, ruling that zoning does not constitute a governmental taking. ${ }^{19}$ Also, the Supreme Court has consistently ruled that the rights to property do not include the right to injure or endanger the public - i.e., create a nuisance - and that owners that do so must expect to "suffer regulation without compensation" (Plotkin 1987, p.68).

Government may also "take" a person's property through its right of eminent domain. This action typically involves the physical invasion of the property, either by the government itself or where the government allows a third party(s) to invade the property. Through eminent domain the governmental unit will acquire title to the property and become its legal owner to use the property for a public purpose. This action is similar to a private sale of the property from the owner to the government. Therefore, in the end, the private owner has no legal connection to the property anymore.

\section{Regulatory Takings}

A regulatory taking occurs whenever there has been a diminution in the market value of land caused by either a new law, or a governmental action under an existing law, such as the Endangered Species Act (Fellows 1996). Therefore, a regulatory taking is very different from an outright seizure, such as what might occur through eminent domain. For instance, a regulatory taking does not entail a transfer of title, and often times it involves only a portion of the property

\footnotetext{
${ }^{19}$ See Village of Euclid v. Ambler Reality Co., 272 U.S. 365, 395 (1926), and Nectow v. City of Cambridge, 277 U.S. 183, 187 (1928).
} 
at stake. Also, a regulatory taking is different from a land use restriction through zoning when the regulation provides a "reasonable use over a reasonable period of time" as measured by a comprehensive plan (Freilich and Garvin 1993). The following scenario illustrates the basic issues that surround regulatory takings.

Aaron owns 100 acres of real estate on which he wants to develop a condominium complex. The fair market value of the property is $\$ 10$ million. Just before construction begins, the Environmental Protection Agency discovers that butterflies of an endangered species inhabit the area. Aaron is ordered to stop any property development pursuant to the Endangered Species Act. The restriction on the development causes the fair market value to drop to $\$ 4$ million. Note that in this scenario Aaron still owns the property, there has been no transfer of title, and the government has not seized the property through its right of eminent domain. However, Aaron has lost the ability to use the property to obtain its fullest worth. As a result, the property value of the land has been reduced by $\$ 6$ million. Has a taking occurred? Should the Fifth Amendment be applied in this scenario? Should compensation be paid to Aaron for the diminution in property value? These issues are, in simple terms, the issues that surround regulatory takings.

As in any conflict, there are two sides to the story. Those who support Aaron (the property owner) argue that he deserves to be compensated by the government for the $\$ 6$ million loss in property value. The view is that the government, through its regulation, has "taken" the value from him and accordingly owe him \$6 million. It is important to note that those in favor of government compensating Aaron are not necessarily against the environmental restriction. Instead, they feel that the owner should receive compensation for the loss in value brought on by the regulation. Critics of this view argue that Aaron still owns the property, which could 
conceivably rise in value again even with the environmental restriction. If this were to happen after government compensated Aaron the \$6 million, would Aaron return any portion of the payment? In addition, the critics argue that, as a investor in real estate, Aaron must understand the risks involved and that there are no guarantees against changes in the market value caused by any number of factors, including government action.

As before mentioned, a regulatory taking is different from any action resulting from government's police power and its right of eminent domain. Most importantly, a regulatory taking is not an categorical condemnation of property by the government. A regulatory taking generally involves only a partial taking. That is, it usually results in the elimination of only a fraction of the property value, even though the restriction applies to the property as a whole. Yet, a regulatory taking can result in the loss of the entire value of the property. A regulatory taking also applies when only part of the property is restricted, such as when the government mandates an easement to use the property as a quid pro quo with the owner.

In sum, the issues surrounding regulatory takings have become the topics for heated debate, both in government and society. This is no surprise given the legal and economic implications involved. The call for action to resolve this issue is backed by national extractive resource associations like the American Mining Congress and the American Petroleum Institute, in conjunction with the American Farm Bureau and the National Association of Realtors, as well as local land owners and recreationists. Property owners have traditionally turned to the courts to resolve their grievances with the government. More recently, Congress and the state legislatures have gotten involved in trying to resolve the takings issue. Yet, in most cases, their efforts have fallen short of a decisive resolution. The following section will review the legal history of the 
takings issue to determine what guidance the courts have provided over this issue.

\section{Judicial Resolve}

The judicial system is the principle arbitrator in land-use decisions and conflicts surrounding private property rights. It has become the key decision maker for several reasons: 1) the fact that state statutes have failed to provide legal guidance to localities concerning the issue (Wenner and Dutter 1988); and, 2) the growing number of constitutional challenges to governmental regulations (Kriz 1993). Additionally, given the legal and economic implications of deciding when a regulatory taking occurs and the criteria for compensation, it is appropriate to insist that this decision making be objective and neutral, and not influenced by the personal objectives and biases of those affected by the decision. Arguably, the best qualified American institution to make such decisions is the judiciary. This claim is based on a key aspect of the judicial process that governs judicial decision making - stare decisis. This principle requires courts to adhere to the rule of law or, when they do not, they at least must clearly justify significant departures in light of articulated changes in circumstances, social needs, or information that necessitates a reevaluation of old rules (Butler 1997). Thus, the nature of the judicial process serves to promote objective and independent decision making.

In early takings cases, Mugler v. Kansas \{123 U.S. 623 (1887\} and Hadacheck v.

Sebastian \{239 U.S. 394 (1915)\}, the Supreme Court declined to find takings for regulations that served significant public purposes despite a significant impact on property value. Shortly after those rulings the Court's 1922 decision of Pennsylvania Coal v. Mahon \{260 U.S. 393 (1922)\} established for the first time that the mere regulation of property, even for valid purposes, might 
constitute a taking if the court finds the regulation's costs to the property owner to be excessive. The Pennsylvania Coal case involved the legitimacy of Pennsylvania's Kohler Act which prohibited mining that caused subsidence under any house, street, or public building. In defending its regulation, Pennsylvania argued that the new law was an exercise of its police power to protect public health and safety and, therefore, immune to a takings challenge. The coal companies, being the major landowners of northeastern Pennsylvania during the late nineteenth century, often sold the surface rights to individuals on the condition that the company retain the mineral rights to the property and that the buyer waives any rights to future claims against the company for subsidence damages. The mining company argued that the regulation constituted an unconstitutional taking of private property without just compensation.

The Supreme Court ruled that despite the law's good intentions, the regulation violated the Fourteenth Amendment's due process guarantees and that the state must buy the company's interest in order to achieve its goal constitutionally. This marked the first time the Court recognized that a regulation could result in an unconstitutional taking and require compensation regardless of whether the government physically occupied or assumed title of the property.

In expressing the Court's opinion of when a regulation constitutes a taking, Justice Oliver Wendell Holmes wrote, "While property may be regulated to a certain extent, if the regulation goes too far, it will be recognized as a taking" $\{260$ U.S. 393, p.415 (1922)\}. However, Justice Holme's did not elaborate on the court's determination of what was meant by "too far," and the courts were left to interpret the concept based on the facts and circumstances of subsequent takings challenges. Therefore, the infamous "too far" edict did little to clearly determine when a regulatory taking occurred. 
Despite the Court's recognition of a regulatory taking in Pennsylvania Coal, it did not invalidate a single governmental action as a regulatory taking for the next sixty years. Instead, in a number of cases the Court upheld land use restrictions on property use despite substantial economic loss. ${ }^{20}$

The Supreme Court attempted to establish a criteria for determining when a compensable taking has occurred in its 1978 ruling in Pennsylvania Central Transportation Co. v. New York \{438 U.S. 104 (1978)\}. The criteria to be considered when evaluating the takings implications of a government action are:

1. The character of the government action,

2. The economic impact of the action on the claimant, and

3. The extent to which the regulation has interfered with the distinct, investment-backed expectations of the owner (Marzulla 1988, p. 10255).

The facts of the Penn Central case are that in 1965 New York City passed the Landmarks Preservation Law in the effort to protect historic buildings and districts. The law was administered by the Landmarks Preservation Commission. In 1968, a joint proposal by Penn Central and UGI Properties was submitted to the Commission to build a fifty-five-story office building in the airspace over Grand Central Terminal (which was designated a historical landmark in 1967). The Commission denied the permit, and Penn Central and UGI Properties filed suit claiming that the application of the Landmarks Preservation Law constituted a taking of their property without just compensation.

In deciding in favor of the City, the Supreme Court ruled that the restriction prohibiting developing the airspace above the terminal constituted only one property right. The owners were

${ }^{20}$ E.g., Village of Euclid v. Ambler Reality Co., 272 U.S. 365 (1926). 
still able to utilize the property as a terminal, which in the courts opinion, offered a reasonable investment return. Also, the Court determined that the regulation was not arbitrarily applied, but affected other property owners as well, who were similarly burdened and benefitted from the law. A decade passed before another significant takings case appeared before the Supreme Court. In 1987 the Supreme Court decided three principal takings cases - Keystone Bituminous Coal Association v. DeBenedictus \{480 U.S. 470 (1987)\}, First English Evangelical Lutheran Church of Glendale v. County of Los Angeles \{482 U.S. 304 (1987)\}, and Nollan v. California Coastal Commission \{483 U.S. 825 (1987)\}. Also, in 1988 the Court rendered a crucial decision in Agins v. City of Tiburon $\{447$ U.S. 255 (1988)\} with regards to regulatory takings. Despite the new conservative Court's willingness to hear the takings challenges, the rulings did not define precisely what constitutes a regulatory takings. The brief review of these cases will clarify this point.

The first case, Keystone Bituminous Coal Association v. DeBenedictus, dealt with the traditional police power of state land use regulation. Pennsylvania passed the Bituminous Mine Conservation Act ("Subsidence Act") which prohibited bituminous coal mining that could lead to cave-ins, collapses, or subsidence that could damage public buildings, human dwellings, and cemeteries. The reported goal of the Act was to "guard the health, safety, and general welfare of the public." ${ }^{21}$ The Pennsylvania Department of Environmental Resources enforced the statute by regulation, one of which required the coal miners to leave 50 percent of the coal in place under the protected structures in order to prevent subsidence. ${ }^{22}$ An association of mining interests

\footnotetext{
${ }^{21}$ Pennsylvania Stat. Ann. Tit. 52, Section 1406.4.

22480 U.S. 470, p.476-77 (1987).
} 
sought an injunction, on the grounds that the regulation resulted in the state effectively taking 27 million tons of coal (which equaled only 2 percent of the total coal seam) without compensation.

In upholding the legitimacy of the Subsidence Act, the Supreme Court cited the precedent set in Pennsylvania Coal that a regulation that goes "too far" would be considered a taking. Yet, it distinguished the case from its predecessor by concluding that there was not a sufficient diminution in property value to constitute a regulatory taking. In deciding the case, the Supreme Court reasoned that since the same person owned the "support estate" (matter below the surface) and either the surface estate or the mineral estate, that the support estate was only one "strand" in a larger "bundle" of property rights. The Court asserted that when determining whether governmental action constitutes a taking it should evaluate the impact of the regulation relative to the property as a whole. Since mining the 27 million tons of coal represented only one "strand" of property rights, the state's regulation was not excessive because it did not destroy the larger "bundle" of rights, which still included the right to mine coal profitably. Therefore, the Court ruled the Subsidence Act was not a taking because it advanced a legitimate public interest, it prevented a nuisance, and it still allowed the company an opportunity to make a profit.

In the second case, First English Evangelical Lutheran Church of Glendale v. County of Los Angeles, the court ruled for the first time that compensation was due for the loss of land value during the time a regulation went into effect and the time the Court subsequently struck down the ordinance as a regulatory taking. The facts of the case have the First English Evangelical Lutheran Church buying 21 acres of land in 1957 to use as a campground and recreation area. In 1978 a flood destroyed all the buildings on the grounds. In response to the disaster the County of Los Angeles banned all building and construction in flood control areas, 
which included the Church's land. Consequently, the Church filed a claim alleging that the ban denied all use of its land and, thus, was a governmental taking without compensation.

In deciding the case, the Court did not decide whether or not the regulation in question constituted a taking. Instead, it addressed the issue of remedies available after a taking has occurred. It agreed that the church was entitled to compensation for the period of time that the regulation denied all reasonable use of the property. The majority ruled that once private property has been taken, just compensation is required from the date the regulation affects the property until the date when the government either revokes or amends the regulation. The Court held that the invalidation of the regulation only limits that compensation by avoiding the continuation of the taking. However, invalidation alone does not constitute just compensation for the time the regulation remained in effect (Eisenberg 1988). Chief Justice Rehnquist stressed this point in declaring that "the constitution guarantees the compensation remedy when a taking occurs, regardless of the duration of the taking, or of subsequent governmental action intended to remedy the situation." ${ }^{, 23}$ The property rights movement may look at this ruling as a victory. It ensures that compensation will be paid to the landowner for losses incurred as a result of a regulatory taking, no matter how long the property owner was subject to the regulation.

It is worth reiterating that the First English case did not provide any guidance in determining when a regulatory taking occurs. Instead, it further established the guarantee of the compensation remedy when a governmental action is determined to be a taking. In making this point, Chief Justice Rehnquist repeated a well established resolution that government regulation of property rights can be a taking and concluded that after a regulation does effect a taking, the

\footnotetext{
23482 U.S. 304, p.321 (1987).
} 
duration of that regulation is irrelevant to the requirement of compensation. He wrote, "the only difference between a permanent taking and a temporary taking is that the valuation of the compensation is less in the latter instance, because the government should only have to pay compensation for the time during which its regulatory taking was in effect." 24

In the third case, Nollan v. California Coastal Commission, the Court addressed the practice by local governments of requiring land or financial contributions by developers to help offset the cost of public facilities necessitated by their development. In this case, the Nollans owned a beachfront lot located between two public beaches. When the Nollans decided to build a new house on their lot, they applied for a permit from the California Coastal Commission as the law required. The Commission granted the permit on the condition that they set aside a strip of their property so that the public may move between the two beaches. The Commission defended the condition on the grounds that the new house would reduce the view of the beach from the street and prevent the public "psychologically" from realizing that a stretch of coastline existed nearby that they are able to access. The Nollans protested the condition, arguing that it amounted to an unconstitutional taking without compensation.

The Supreme Court ruled that the Commission violated the Takings Clause of the Fifth Amendment by requiring the property owners to convey an easement across their property before they could receive a permit to build their home. In writing its decision, the Court asserted that a development condition, or extraction, does not constitute a taking as long as it advances a legitimate governmental interest or is adopted in response to the specific needs created by the development. In other words, there must be an "essential nexus," or necessary connection,

\footnotetext{
${ }^{24} 482$ U.S. 304, p.319 (1987).
} 
between the governmental mandate to the property owner and the public interest in order for the regulation not to amount to a taking. In the Nollan case, however, the Court found that there was an insufficient connection between the required extraction and the impact of the proposed development, suggesting that its real purpose was an attempt to obtain a public easement without providing compensation (Symons 1988; Blaesser et al. 1989).

In 1988, the Supreme Court decided the case of Agins v. City of Tiburon that involved an open-space zoning ordinance limiting the number of homes that could be built on a tract of land. In ruling against the property owner, the Court developed a two-part legal test, the "Agins test," to determine whether the government had gone too far and caused a regulatory taking. The Agins test determines that a regulatory taking occurs if the government's action either:

1. Exhibits an "impermissible use" of the government's police power, or

2. Denies the property owner "economically viable use" of the property (Fellows 1996).

If either of these conditions apply, then the government must compensate the owner for the loss in property value. In writing for the majority, Justice Lewis Powell clarified what "impermissible use" means by stating that the regulation or action must "substantially advance legitimate state interests" or else it would be considered an illegitimate use of the government's police power. Further elaborating on the impermissible use concept, the Court held that two subsidiary conditions must be met by the government. First, there must be an essential nexus between the regulation and the public interest. Second, there must be a reasonable relationship between the regulation and the public benefits. In other words, once the nexus between the regulation and the public interest is established, it must be proven that it is more than a loosely connected one. Having settled the Agins case under the first criterion of the Agins test, the Court 
failed to expand upon the second criterion which deals with "economically viable use." However, the opportunity to address this issue reappeared just five years later in a landmark property rights case.

In the 1992 case, Lucas v. South Carolina Coastal Council \{112 S. Ct. 2886 (1992)\}, the Supreme Court addressed the second criterion of the Agins test dealing with economically viable use. The case involved the state adoption of developmental restraints in coastal lands located within so-called “critical areas.” In 1986, David Lucas (the plaintiff) purchased two residential lots on the Isle of Palms, a barrier island in Charleston County, South Carolina, for $\$ 975,000$ with the intention to build single family homes on each of the lots. Two years later, South Carolina passed the Beachfront Management Act, which sought to preserve sensitive coastal areas by prohibiting construction within so-called "critical areas" of the shoreline. As a result, both of Lucas's lots were affected and he was effectively prohibited from building any structures on his property.

Lucas sued claiming that the Beachfront Act, despite its legitimate intention to protect South Carolina's beaches, denied him all economically viable uses of his property and, thus, was a taking that required compensation. The state argued that the "nuisance exception" to the takings clause allowed the regulation since it was aimed at both protecting the environment and preventing public hazards that might occur as a result of storm damage to the property's structures (Moffett 1996). The Supreme Court ruled in favor of Lucas, expressing that the state must rely on laws in force at the time the property was purchased to justify its developmental restraint. Also, the Court felt that the Act was an invalid exercise of the state's police powers to 
mitigate the potential harm to the public interest that Lucas's land might occasion. ${ }^{25}$

The Court justified its takings decision based upon the "economically viable use" concept as well. The Court suggested that, from the landowners perspective, total deprivation of beneficial use was equivalent to a physical appropriation of the land. Therefore, "when the owner of real property has been called upon to sacrifice all economically beneficial uses in the name of the common good,... he has suffered a taking." ${ }^{26}$ The court further noted that in such a case, the regulatory action is compensable without the usual inquiry into the public interest advanced by the regulation (Delaney 1993). The Court's ruling eventually led to the state's outright purchase of the land from Lucas for over $\$ 1.5$ million.

The Lucas decision was a small victory for property owners in that it established the right to be compensated when a governmental regulation eliminates all economic use of one's land. It should be noted, however, that this represents an odd case, and even the Supreme Court acknowledged that a total economic loss was an "extraordinary circumstance" (Greenhouse 1992; Kenworthy and Downy 1992). On the other hand, environmentalists claimed the Lucas decision as victory for themselves because the requirement of compensation only applied to instances where there was total economic loss. This suggests that regulatory decisions reducing the value of land by anything less that one hundred percent were not necessarily compensable.

The Agins test was revisited in the most recent Supreme Court takings case, Dolan v. City of Tigard $\{114$ S. Ct. 2309 (1994)\}. The Court again was asked to determine whether a government mandated extraction in return for a building permit constituted an "impermissible

\footnotetext{
${ }^{25} 112$ S. Ct. 2886, p.899 (1992).

${ }^{26}$ Ibid. p. 2895
} 
use" of the state's police power. In the Dolan case, the city of Tigard, Oregon granted Florence Dolan (property owner and plaintiff) a permit to expand her hardware store and its parking lot on the condition that she dedicate land to improve a storm-drainage channel and a pedestrian / bicycle path. The city argued that these extractions were necessary to minimize flooding and relieve traffic congestion that might be caused by the additional traffic to her store. Together, the extractions would have taken ten percent of her 1.7 acre lot for public use, and there was to be no compensation for the public easements. Dolan sued, arguing that the city did not compensate her for effectively taking the property.

The Supreme Court ruled in favor of Dolan, citing their earlier decision in Agins. The Court acknowledged the validity of the city's goal to advance a legitimate state interest, following the first prong of the Agins test. Yet, the Court reiterated that the first prong of the Agins test had two subsidiary conditions, and both conditions had to be met for the government to accomplish an uncompensated taking. Therefore, once the essential nexus was established (a valid state interest involved), the state had to show that there was a reasonable relationship between the state interest and the government mandate to the property owner (Fellows 1996). The state failed in this second part, and the court ruled that the conditions set for the permit approval were disproportional to the anticipated impacts of development and, thus, constituted a violation of the Fifth Amendment's Takings Clause (Biskupic 1994; Greenhouse 1994).

In summary, the legal history of the regulatory takings issue has shown that the Supreme Court has yet to provide clear guidance as to what governmental actions constitute a taking, and the circumstances under which a taking is compensable. Except when the government exercises its power of eminent domain and physically invades one's property, and in the very narrow case 
when a government regulation deprives an owner of all "economically viable" use of the land, the U.S. Supreme Court has failed to define when a governmental regulation constitutes a taking. Instead of offering clear guidance, the Court has based its rulings on vague decrees, such as the infamous "too far" edict, the "bundle of property rights" theory, and the "essential nexus" condition, and offered only indefinite formulas to determine when compensable takings occur. Recent rulings (e.g., Lucas and Dolan) have favored the property owner, and have been viewed as victories by the property rights movement. However, the precedents set by the Supreme Court should not be taken as an indication that the judicial system is now the refuge for property owners seeking protection from governmental regulations. The principle of stare decisis, following precedent, only has to be followed by lower courts if the facts in a subsequent case are similar to the precedent case. This is very unlikely to happen given the uniqueness of each takings challenge. This means that the precedents set by the Supreme Court thus far will not necessarily be universally applied. Therefore, as a result of the Court's uncertainty, and the likelihood that precedents will not be followed, the proponents of property rights have incentive to seek other institutional locations that may provide a more definite resolution to this conflict. The next Chapter follows this issue as it is taken up in Congress. 


\section{CHAPTER FOUR}

\section{Tracking the Property Issue in Congress}

It is important to my argument that I demonstrate the property rights community has gained access to the governmental agenda at the national level. This is a key point. If I can show that the property rights community has gained access in Congress, but have still been unable to realize legislative success, then my argument contending that the property rights movement strived to shift the issue's venue to the states becomes more reasonable. Otherwise, my venue shifting argument lacks the evidence which provides the property rights community the incentive to seek another venue.

I begin this chapter with a discussion of property rights legislation. I will explain the various type of property rights legislation, paying particular attention to the type of legislation that concerns regulatory takings, referred to as takings legislation. I will also provide an overview of the federal legislative attempts to resolve the regulatory takings issue. Then, I conduct a series of studies to explore the property issue in Congress. More specifically, I will be testing several hypotheses regarding the property rights community's challenge for control of the political agenda regarding property issues. First, I will provide an overview of the property issue in Congress, including its salience on the governmental agenda and the topics of the property hearings. Second, I will argue that a Schattschneider mobilization occurred by studying the nature of the property hearings and the participants of the property hearings. In these sections, I will demonstrate that Congress has been concerned with the interests of the property owner in its consideration of property matters, and that representatives of the property rights community have 
gained access to the property hearings in Congressional committees. Third, I will test for jurisdictional control by committees over the property issue. The relevant hypothesis is:

$H_{1}$ : Environmental committees have maintained jurisdictional control over the property issue in Congress.

Fourth, I will check to see if the committees holding property hearings favored certain groups. The relevant hypothesis is:

$\mathrm{H}_{2}$ : Environmental committees favored environmental witnesses in property hearings.

Finally, I will distinguish between legislative and nonlegislative hearings to determine if the latter were used as a means by which committee chairs challenge for control of the political agenda. The relevant hypothesis is:

$H_{3}$ : Committee leaders used nonlegislative hearings to redefine the property issue in the attempt to gain future bill referrals.

Following my studies, I will discuss my findings in the hopes of providing a description of the battle for control over the political agenda regarding property matters.

\section{Legislative Resolve}

As noted in the previous chapter, the judicial system has failed to provide a definite resolution to the regulatory takings issue, except in narrowly defined cases. Thus, in recent years, property rights proponents have sought to codify regulatory takings law by working through the U.S. Congress and state legislatures. The idea is that if legislation can be enacted on regulatory takings, then property owners would not have to face the uncertainties of the judicial system, where cases are decided on an ad hoc basis. The following section explains the various types of 
property rights bills that have been introduced to Congress.

\section{Property Rights Legislation}

Essentially, any piece of legislation that intends to protect the property owner from having to carry a disproportionate burden of a government action may be viewed as a property rights bill. Yet, a close look at the content of the bills introduced to Congress indicates that property rights legislation serve different objectives. Since the late 1970s, approximately sixtysix property rights bills have been introduced to Congress (see Appendix 1 for complete listing of introduced property rights legislation from 1977 - 1998). ${ }^{1}$ For the purpose of this study, I have categorized the numerous types of property rights legislation into five groups based on their content. The five categories of property rights legislation are: symbolic (S); eminent domain assessment (EDA); eminent domain compensation (EDC); takings assessment (TA); and, takings compensation (TC). A brief description of each type of property rights legislation follows.

Symbolic legislation seeks to increase awareness over an issue. Between 1977 and 1998, only one property rights bill was introduced to Congress that may be considered symbolic. H.J. Res. 261, or the "Joint Resolution to designate the third week in April each year as 'National Private Property Week,"' was introduced in 1977 to direct the President of the United States to issue a proclamation calling for appropriate observance of such week. ${ }^{2}$

Eminent domain assessment (EDA) legislation tries to establish policies and procedures, including restriction and exchange requirements, to be followed by federal agencies prior to the

\footnotetext{
${ }^{1}$ I was limited to studying property rights legislation only as far back as 1977 because Thomas, the search engine for legislative information on the internet (http://thomas.loc.gov), only goes back that far.

${ }^{2}$ H.J. Res. 261, $95^{\text {th }}$ Congress, $1^{\text {st }}$ Session (1977).
} 
acquisition of private lands or interests in private lands. An example of EDA legislation is H.R. 8141, or the "Bill to amend the Uniform Relocation Assistance and Real Property Acquisition Policies Act of 1970," introduced in 1980. ${ }^{3}$ Among other things, H.R. 8141 requires a federal agency to prepare a Land Acquisition Plan before acquiring lands or interests in lands which balances the need for acquisition against the costs and impacts on private landowners and state and local governments. Also, the proposed bill would establish a Land Policy Group which would, inter alia, develop uniform land acquisition procedures, and review appeals by private land owners or state and local governments concerning federal land acquisitions.

Eminent domain compensation (EDC) legislation seeks to reimburse real property owners for the costs incurred because of a federal project or an act of condemnation by a federal agency, such as the National Park Service. An example of such legislation is S. 1108, or the "Uniform Relocation Assistance Act Amendments of 1979," introduced in 1979. ${ }^{4}$ S. 1108 amends the Uniform Relocation Assistance and Real Property Acquisition Policies Act of 1970 to require that relocation benefits, including relocation assistance advisory services, be made available to all persons displaced by the commencement of a federal or federally assisted project. Also, the bill requires the head of a federal agency administering or financing such a project to offer to acquire property from any person owning property affected by the project who is left with an uneconomic remnant in order to entitle the owner and occupant full benefits under this Act. Another example of EDC legislation is H.R. 4022, or the "Bill to compensate...ranchers for ranching units taken by the Department of the Army for the White Sands Missile Range, New Mexico," introduced in

\footnotetext{
${ }^{3}$ H.R. $8141,96^{\text {th }}$ Congress, $2^{\text {nd }}$ Session (1980).

${ }^{4}$ S. $1108,96^{\text {th }}$ Congress, $1^{\text {st }}$ Session (1979).
} 
1983. ${ }^{5}$ H.R. 4022 directs the Secretary of the Treasury to compensate ranchers whose lands were taken for national defense purposes after 1941 and are now part of the White Sands Missile Range, New Mexico.

Between 1977 and 1991, most of the property rights legislation introduced to Congress was the eminent domain compensation type, dealing with the consequences to property owners because of the federal government exercising its right of eminent domain (see Appendix 1). Beginning in 1991, two different types of property rights legislation that dealt more directly with the regulatory takings issue began appearing in Congress. These types of bills are generally referred to as takings legislation, and seek to protect the property owner from the effects of a regulatory taking. A regulatory taking occurs whenever there has been a diminution in the market value of land caused by either a new law or regulation, or a governmental action under an existing law, such as the Endangered Species Act (Fellows 1996).

Takings legislation generally comes in two forms. The first type is referred to as takings assessment (TA) legislation, or "look before you leap" statutes. This type of legislation requires government agencies to assess whether their actions might constitute an unconstitutional takings under either federal or state supreme court decisions (Cordes 1997). Takings assessment legislation is usually patterned after President Reagan's Executive Order 12630 and require some form of 'takings impact analysis' (TIA) before a federal agency could pursue any action which could result in a taking or diminution of the use or value of private property. Typically, this also involves developing economic impact statements identifying and valuing the impacts of any proposed government regulation on private property. An example of a TA bill is H.R. 4418, or

\footnotetext{
${ }^{5}$ H.R. 4022, $98^{\text {th }}$ Congress, $1^{\text {st }}$ Session (1983).
} 
the "Private Property Rights Act of 1994," introduced in 1994. ${ }^{6}$ H.R. 4418 attempted to make it the federal government's policy to use all practical means and measures to minimize federal takings of private property, including directing federal agencies to certify to the Attorney General that a private property taking impact analysis had been completed before initiating any action which could result in a taking or diminution of use or value of private property. A subsidiary of the takings assessment type legislation that has been introduced in the states are called Attorney General (AG) review bills. AG bills require the state attorney general to develop guidelines, based on the explicit principles included in the statute, for the government to use in determining whether its actions have constitutional takings implications (Lund 1995).

The second type of takings legislation is referred to as takings compensation (TC) legislation. Takings compensation statutes essentially define a taking. In most cases, the laws include the requirement for a takings impact analysis and establish a threshold at which a percentage diminution in value triggers the requirement for compensation, either for the lost value or for the entire value of the land. An example of a TC bill is H.R. 925, or the "Private Property Protection Act of 1995," introduced in 1995. ${ }^{7}$ H.R. 925 requires the federal government to compensate a property owner whose use of that property has been limited by an agency action, pursuant to a specified regulatory law, that diminishes the fair market value of that property by 20 percent or more, for that diminution in value. Also, the bill requires the government to buy at fair market value any portion of a property whose value has been diminished by more than 50 percent.

\footnotetext{
${ }^{6}$ H.R. $4418,103^{\text {rd }}$ Congress, $2^{\text {nd }}$ Session (1994).

${ }^{7}$ H.R. 925, $104^{\text {th }}$ Congress, $1^{\text {st }}$ Session (1995).
} 
The previous section describes the various types of property rights legislation. Although each type has a different focus, they all serve the overriding purpose of protecting the rights of the property owner. The following section will report the history of federal takings legislation to determine what efforts Congress has made to protect private property interests from government regulation (see Appendix 1 for complete listing of introduced property rights legislation from 1977 - 1998). The historical report pays exclusive attention to takings law because it concerns the issue which is the focus of this study.

\section{Federal Takings Legislation}

The Legislative approach to dealing with the regulatory takings issue may be traced back to the federal Executive Order 12630 issued by Ronald Reagan in 1988. Executive Order 12630 aimed to force federal agencies to consider the takings implications of their regulations and to budget money to pay for necessary takings. ${ }^{8}$ Most assessment type takings legislation is patterned after Executive Order 12630, and require some form of 'takings impact analysis' (TIA) before a federal agency could pursue any action which could result in a taking or diminution of the value of private property. Despite the objectives of Executive Order 12630, it suffers from two problems. First, it applies only to executive departments and agencies, and not to state and local government regulatory agencies. Second, and more importantly, the Clinton administration is not enforcing the order (Lipford and Boudreaux 1995). For all practical purposes, Executive Order 12630 is a lame duck decree and property rights advocates are unable to claim it as a success. In

\footnotetext{
${ }^{8}$ Executive Order No. 12630, 3 C.F.R., section 554 (1989), reprinted as amended in 3 U.S.C., section 301 (Supp. 1995)
} 
fact, the proponents of federal takings legislation have had very little success in the legislative realm. Although, it may be argued that the mere consideration of takings legislation by Congress is progress, given that the idea of takings legislation is still relatively new.

Federal takings legislation was first introduced in 1991 (see Appendix 1).That year, four takings assessment bills were introduced to Congress that intended to give Executive Order 12630 the force and effect of law. ${ }^{9}$ However, none of the four bills were reported out of committee. 1991 also saw the first takings compensation bill introduced to Congress. H.R. 2185, or the "Just Compensation Act of 1991," was introduced by Representative R.F. Smith and required the head of any federal agency who takes action under the Endangered Species Act, the Surface Mining Control and Reclamation Act of 1977, or under specified provisions of the National Trails System Act or of the Federal Water Pollution Control Act relating to wetlands to compensate the owner of private property for any (author's emphasis) diminution in value caused by the action. ${ }^{10}$ H.R. 2185 died in committee. Despite the failure of these early attempts to pass takings legislation, they serve one important function. The introduction of these bills established that the regulatory takings issue reached the governmental agenda. This is an important point, regardless of legislative success. Their introduction and mere consideration may be deemed a success by the property rights proponents.

Federal takings compensation legislation was again introduced in 1994. The most notable were H.R. 3875, entitled "Private Property Owners Bill of Rights,"and its Senate companion bill

${ }^{9}$ S. 50, "Private Property Rights act of 1991," $102^{\text {nd }}$ Congress, $1^{\text {st }}$ Session (1991); H.R. 905, "Property Rights Act of 1991," $102^{\text {nd }}$ Congress, $1^{\text {st }}$ Session (1991); H.R. 1572, "Private Property Rights Act of 1991," $102^{\text {nd }}$ Congress, $1^{\text {st }}$ Session (1991); and, H.R. 1650, "Private Property Rights Act of 1991," $102^{\text {nd }}$ Congress, $1^{\text {st }}$ Session (1991).

${ }^{10}$ H.R. 2185, $102^{\text {nd }}$ Congress, $1^{\text {st }}$ Session (1991). 
S. 1915. These bills provided a right to compensation for property owners who suffer a diminution of property value of 50 percent or more as a result of an agency action under the Endangered Species Act or the section 404 wetlands program of the Federal Water Pollution Control Act. ${ }^{11}$ The bills were limited to those two laws. Although the bills were never considered seriously, they served an important function. They established the diminution of value approach to compensation that would later shape similar legislation and the debate concerning regulatory takings (Sax 1996). Takings assessment legislation was also introduced in 1994. S. 2006, or the "Private Property Rights Act of 1994," and its House companion bill H.R. 4418, attempted to make it the policy of the federal government to use all practical means and measures to minimize federal takings of private property. Also, the bills directed federal agencies to certify to the Attorney General that a private property takings impact analysis has been completed before initiating any action which could result in a taking or diminution of use or value of private property. ${ }^{12}$ Overall, six takings statutes were introduced to Congress during 1994. And, although none of the bills made it past committee consideration, they served to place the regulatory takings issue firmly on the governmental agenda by assuring that the issue would be one to be reckoned with in Congress.

Takings legislation was also introduced as part of the "Contract with America," proposed by the House Republican Conference in 1994. As part of the Contract, a bill entitled the "Job Creation and Wage Enhancement Act of 1995" included a provision entitled Title IX, or "Private Property Rights Protection and Compensation." ${ }^{13}$ Title IX's objective was clearly conveyed in

\footnotetext{
${ }^{11}$ H.R. 3875, 103d Congress, $2^{\text {nd }}$ Session (1994) and S. 1915, $103^{\text {rd }}$ Congress, $2^{\text {nd }}$ Session (1994).

${ }^{12}$ S. 2006, $103^{\text {rd }}$ Congress, $2^{\text {nd }}$ Session (1994) and H.R. 4418, $103^{\text {rd }}$ Congress, $2^{\text {nd }}$ Session (1994).

${ }^{13}$ H.R. 9, $104^{\text {th }}$ Congress, $1^{\text {st }}$ Session (1995).
} 
one sentence that read, "A private property owner is entitled to receive compensation...for any...limitation or condition that is imposed by a final agency action on a use of property that would be lawful but for the agency action" and is not negligible. ${ }^{14}$ The bill defined "not negligible" as "any reduction in the value of property equal to 10 percent or more." ${ }^{15}$ In the fourth version of the bill, the concept of "not negligible" was changed to be any reduction of 20 percent or more, with an option for the property owner to require government purchase on any reduction of 50 percent or more. ${ }^{16}$

Title IX's measures to provide property owners protection against regulatory takings were seen as too severe to be taken seriously (Sax 1996). Critics argued that a law requiring compensation for any agency action that results in a reduction of any lawful use of property was too absolute. For instance, such a law could require the public to pay pornographers, slum lords, and owners of leaking landfills to cease their activities, so long as no previous law prohibited that same conduct.

Despite Title IX's criticisms, H.R. 9 turned out to be the first instance of legislative success for the property rights proponents as the U.S. House of Representative passed it on March 3, 1995. On the same day, the House also passed H.R. 925, or the "Private Property Protection Act of 1995," ${ }^{17}$ and incorporated it into H.R. 9. H.R. 925 required the federal government to compensate property owners whenever regulatory action causes the value of any portion of the property to diminish by 20 percent or more. Therefore, a government action need

\footnotetext{
${ }^{14}$ Ibid. Section 9002(a) (Jan. 8, 1995).

${ }^{15}$ Ibid. Section $9002(a)(2)(B)$.

${ }^{16}$ Ibid. Section 203(a) (March 8, 1995).

${ }^{17}$ H.R. 925, $104^{\text {th }}$ Congress, $1^{\text {st }}$ Session (1995).
} 
only affect a portion of one's land for the 20 percent test to be applied to that portion.

Furthermore, like Title IX of the Contract bill, H.R. 925 provided the property owner the option of requiring the federal government to purchase any portion of land which is devalued by more than 50 percent as a result of an agency action. ${ }^{18}$ Also, similar to H.R. 3875 that was introduced one year prior, the H.R. 925 protects the property owner from regulatory action pursuant to the protection endangered species and the preservation of wetlands, although it adds a couple of other programs that are impacted by wetlands and endangered species regulation, most notable the Federal Reclamation Law. ${ }^{19}$ The House Act reinforces the government's police powers by requiring no compensation to be paid if the purpose of the regulatory action is to prevent a public nuisance - i.e., prevent a hazard to public safety or health, or to prevent damage to specific property other than the property whose use is limited. ${ }^{20}$

The companion bill to the House Act did not fare as well in the Senate. Introduced by then-Senator Robert Dole, the "Omnibus Property Rights Act of 1995" was reported out of the Senate Judiciary Committee, but was not brought before the full Senate, largely because its proponents lacked sufficient votes to break a threatened filibuster (McCutcheon et al. 1996). Opposition to the Senate bill primarily focused on the fact that the bill had no limitation on coverage, unlike the House Act. To many in Washington, considering a takings bill seriously that covers all agency actions is difficult (Sax 1996). Without more narrowly focused terms,

${ }^{18}$ Ibid. Section 3(a).

${ }^{19}$ Ibid. Section 10. Other statutes included in the scope of H.R. 925 are Title XII of the Food Security Act of 1985, 16 U.S.C., p. 3801-3862 (1994); the Federal Land Management Policy Act, 43 U.S.C., p. 1701-1784 (1994); and Section 6 of the Forest and Rangeland Renewable Resources Planning Act of 1974, 16 U.S.C., pg. 1604.

${ }^{20}$ Ibid. Section 4(a). 
opponents feared that the conditions for compensation may be applied too broadly and the government would end up owing compensation every time an agency's action interfered with an individual's right. Associate Attorney General John Schmidt expressed this scepticism before the Senate Judiciary Committee in 1995 . He pointed out that the bill's confusing terms and conditions may lead to, for example, "compensation for corporations across the country when the Congress suggests a federal legislation designed to stabilize and protect pension plans...or, compensation for agricultural interests that must comply with changing thytosanitary restrictions" (Schmidt 1995).

Overall, twelve takings bills were introduced to Congress in 1995 and 1996 (see Appendix 1). Yet, only H.R. 9 and H.R. 925 offered the property rights proponents an opportunity to claim legislative success. Seven other takings compensation bills died in committee, ${ }^{21}$ along with three takings assessment bills. ${ }^{22}$

1997 witnessed another legislative success for the property rights proponents. The House passed the takings assessment bill H.R. 1534, or the "Private Property Rights Implementation Act of 1997," which requires a federal agency that takes an agency action limiting the use of private property to give notice to the property owners explaining their rights and the procedure for obtaining any compensation that may be due to them. ${ }^{23}$ Five other takings bills, three takings

${ }^{21}$ S. 135, "Property Rights Litigation Relief Act of 1995," $104^{\text {th }}$ Congress, $1^{\text {st }}$ Session (1995); S. 145, "Private Property Rights Restoration Act of 1995," $104^{\text {th }}$ Congress, $1^{\text {st }}$ Session (1995); H.R. 489, "Property Rights Litigation Relief Act," $104^{\text {th }}$ Congress, $1^{\text {st }}$ Session (1995); S. 239, "Private Property Owners Bill of Rights," $104^{\text {th }}$ Congress, $1^{\text {st }}$ Session (1995); S. 605, "Omnibus Property Rights Act of 1995," $104^{\text {th }}$ Congress, $1^{\text {st }}$ Session (1995); S. 768, "Endangered Species Reform Act of 1995," $104^{\text {th }}$ Congress, $1{ }^{\text {st }}$ Session (1995); and, S. 1954, "Omnibus Property Rights Act of 1996," $104^{\text {th }}$ Congress, $2^{\text {nd }}$ Session (1996).

${ }^{22}$ H.R. 130, "Private Property Protection Act of 1995," $104^{\text {th }}$ Congress, $1^{\text {st }}$ Session (1995); S. 22, "Private Property Rights Act of 1995," $104^{\text {th }}$ Congress, $1^{\text {st }}$ Session (1995); and, H.R. 1277, "Private Property Impact Assessment Act of 1995," $104^{\text {th }}$ Congress, $1^{\text {st }}$ Session (1995).

${ }^{23}$ H.R. $1534,105^{\text {th }}$ Congress, $1^{\text {st }}$ Session (1997). 
compensation bills ${ }^{24}$ and two takings assessment bills, ${ }^{25}$ that were introduced to Congress in 1997 and 1998 were never reported out of committee.

Federal legislative attempts at resolving the regulatory takings conflict have primarily focused on the compensation type legislation. However, to date, no federal takings legislation of any type has passed both chambers of Congress. Congress's failure to enact federal takings laws is in part due to the efforts of its opponents, such as the Wildlife Society and the National Wildlife Federation, to warn of its potential sweeping impact on matters ranging from civil rights to drunk driving laws. For example, in 1964, a Georgia motel operator sued the United States, claiming that the 1964 Civil Rights Act requiring him to rent rooms to people of color was a "taking" of his motel property. Also, in 1992, an Arkansas tavern owner sued the state over its sobriety checkpoints, claiming that they hurt business and constituted a taking (Byrnes 1995). While these claims were denied at the time, opponents argue that under proposed takings legislation the outcomes could have been different. Opponents of takings legislation also argue that the TIA process would severely weaken or even repeal public health and safety laws, thus hampering the ability for government to protect the public's interest (Moulton 1995).

Perhaps the strongest reason federal taking legislation has failed is its fiscal impact. Before the Nollan and First English Supreme Court decisions, the federal government paid \$23 million in compensation to takings challenges in 1985, $\$ 5.5$ million in 1986 , and $\$ 20.2$ million in 1987. One year after the two decisions, the federal government had more than $\$ 1$ billion in

\footnotetext{
${ }^{24}$ S. 781, “Omnibus Property Rights Act of 1997," $105^{\text {th }}$ Congress, $1^{\text {st }}$ Session (1997); S. 953, "Private Property Owners Bill of Rights," $105^{\text {th }}$ Congress, $1^{\text {st }}$ Session (1997); and, H.R. 4554, "Endangered Species Land Management Reform Act," $105^{\text {th }}$ Congress, $2^{\text {nd }}$ Session (1998).

${ }^{25}$ H.R. 95, "Private Property Protection Act of 1997," $105^{\text {th }}$ Congress, $1^{\text {st }}$ Session (1997) and S. 709, "Private Property Rights Act of 1997," $105^{\text {th }}$ Congress, $1^{\text {st }}$ Session (1997).
} 
takings claims pending against it (Wise 1992). As a result of the potential high costs of takings legislation, the American public could face an enormous tax burden to pay off the claims, which even one of the sponsors of a takings bill, Billy Tauzin (R-LA) admits would "bankrupt the government."26

In sum, twenty-nine takings bills have been introduced to Congress between 1977 and 1998 to address the issue of regulation takings (see Appendix 1). Despite Congress's failure to resolve the issue by enacting federal takings legislation, the proponents of property rights have been able to claim small legislative victories with the House passing three takings bills. Yet, the hope for future federal legislation protecting property rights seems ever more futile given the fact that President Clinton has threatened to veto any federal property rights bill (Treanor 1997).

The previous section illustrates one certain point. The issue of property rights and regulatory takings has reached and maintains a solid position on the federal governmental agenda. This suggests that the property rights proponents have successfully challenged for control of the political agenda. Also, it gives reason to believe that since they have had no legislative success in Congress, the property rights proponents have greater incentive to shift this issue's venue to the state's. The following sections of this chapter explore the agenda battle over property issues in Congress.

\section{Methods}

In previous studies of the property rights movement, scholars have relied upon interviews with leaders of groups within the property rights community and aggregate data regarding the

\footnotetext{
${ }^{26}$ Taken from Byrnes, “Are We Being Taken by Takings,” (1995).
} 
number of groups and its members to argue that the property rights community has gained a foothold in the policy making community and begun to influence policy regarding property rights (Switzer 1997; Brick 1995). This prior research gives no indication of the community's success in gaining agenda access or influence over policy. For a more relevant assessment, I examined the participants of the Congressional property hearings to determine objectively who had access and influence over this policy. Generally, I employ methods used to assess the property rights community's access to the governmental agenda which are very similar to those utilized by Baumgartner and Jones (1993; 1995), Talbert, Jones, and Baumgartner (1995), and Worsham (1997). Using the Congressional Information Service (CIS) reports on congressional activity and its Hearings Abstracts, I examined all congressional hearings on property, and its appropriate keywords, from $1959-1995 .^{27}$ All told, 266 hearings were reviewed (148 in the House and 118 in the Senate). First, I coded the topic of the hearing to get an understanding of the issue being discussed in the property hearing. Second, I coded the tone of the hearing based on its title and abstract to determine if it favored the environmental interests or the property rights community. The tone of the property hearings were coded either positive or negative from the perspective of the environmentalist. Those hearings addressing environmental protection, the merits of environmental laws, or the creation, expansion, or conservation of public lands were coded positive. Those hearings addressing economic issues (i.e., the negative economic effects of environmental laws and programs), the rights of private interests and/or individuals were coded negative. Therefore, an increase in negatively toned hearings should indicate that Congress is

\footnotetext{
${ }^{27}$ Key words used in the subject search of the CIS Hearings Index included: property, right of property, right-of-way and easements, eminent domain, and land use.
} 
considering the interests of the property owners, and that the property rights community has gained access to the governmental agenda. Third, I coded the hearings according to which committees and subcommittees held them. This allows me to determine which committees have jurisdiction, and whether or not this jurisdiction is dominated by a small number of committees or shared by several. In addition, I grouped the committees and subcommittees into jurisdictional blocks or venues - i.e., committees or subcommittees that might share a policy view or orientation. This venue measure enables me to determine whether the property issue was within the jurisdictional control of a single committee or a group of like-minded committees, or in dispute between hostile groups of committee entrepreneurs with different attitudes towards the issue. Fourth, I distinguished whether the hearings were legislative or nonlegislative. Hearings that review bills are referred to as legislative hearings, and all other hearings (including oversight and investigative) are nonlegislative hearings. The rules of jurisdictional assignment that apply to legislative hearings do not apply when there is no legislation (Talbert, Jones, and Baumgartner 1995). So, the distinction between legislative and nonlegislative hearings relates to an important element of the jurisdictional game. Fifth, I coded every participant who appeared in the hearings by reading the abstract of the witnesses' testimony at the hearing. I distinguish the witnesses as representing a specific group or professional interest: environmental, property rights (private or economic interest), elected officials, or other and uncodeable. The environmental and property rights categories correspond with the two dominate coalitions involved in property issue. In simple words, environmental witnesses are those representing environmental agencies, environmental interest groups, and others likely from their affiliation to focus on environmental issues. Property right witnesses are those representing resource extraction, manufacturing, and 
utility interests, and private citizens and organizations concerned with constitutional and civil rights. Approximately 5340 witnesses appeared in 266 hearings regarding property from 1959 to 1995. After coding all the hearings for participants, I began coding again to check the reliability of my coding scheme. After the first 10 years of recoding, I found approximately 95 percent agreement between the two attempts at coding. Finally, in addition to the previous information, I noted the congressional session of the hearing and the year of the hearing.

\section{Property's Salience}

A longitudinal look at the total number of property hearings serves as an indicator of salience on the government's agenda.

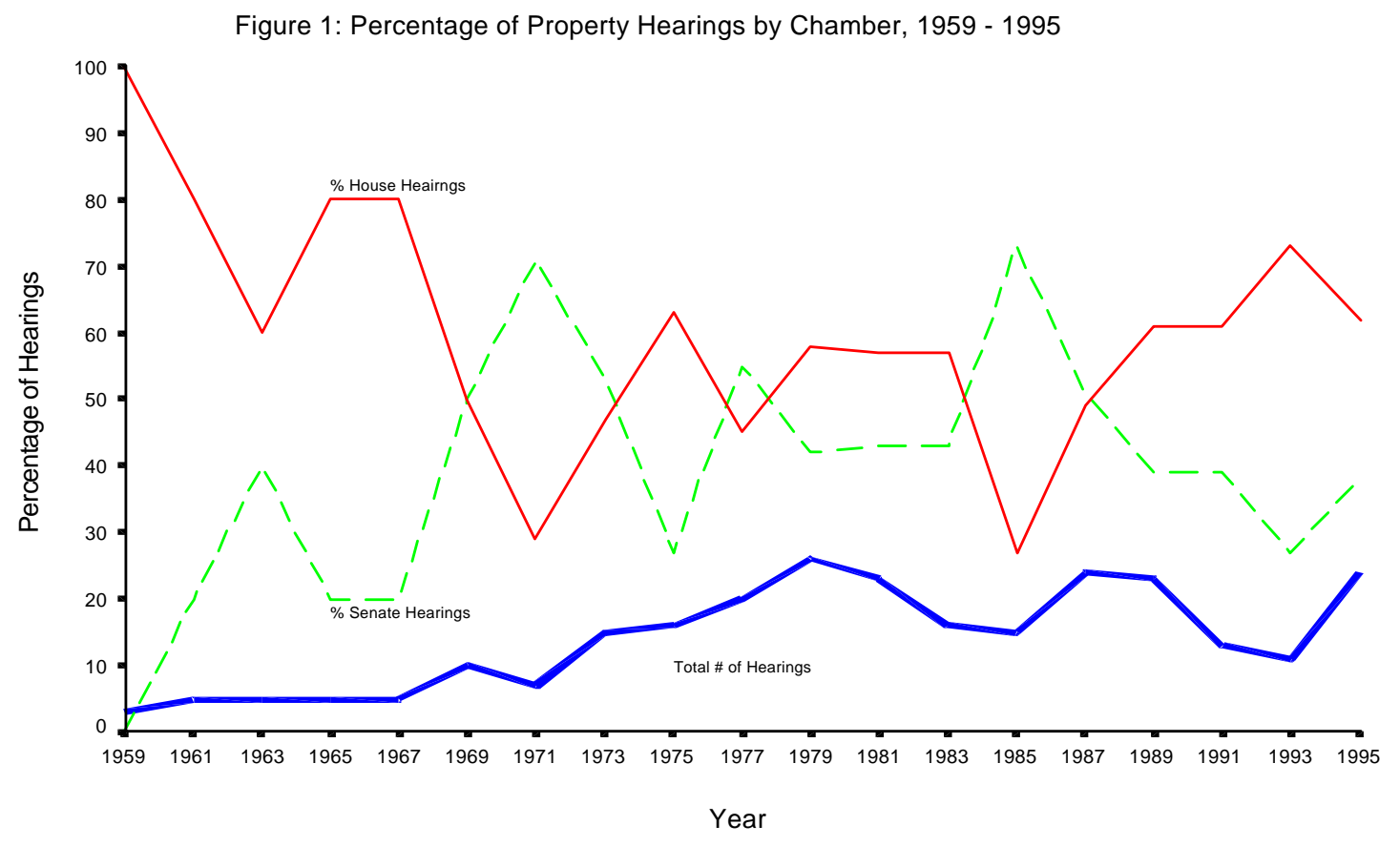


Figure 1 shows that the property issue has maintained a position on the government's agenda, although varying over time in the degree that it receives attention. Few hearings are concerning property issues until the late 1960s. The number of property hearings rises substantially during the 1970s, which is probably because this is the early period of environmentalism marked by high awareness and the passing of many environmental laws. Another explanation potentially affecting the number of property hearings may be the 1974 Congressional committee reform that enabled bills to be directed to more than one committee, thus increasing the opportunity for rival committees to hold hearings. Also, Figure 1 shows that for most of the 1970s property issues remained salient in both chambers. Yet, the Senate held the majority of the property hearings in te early 1970s, and the House held the majority in the latter part of the 1970s and the early 1980s. The number of property hearings begin to fluctuate more during the 1980s. First they drop off markedly, probably due to the anti-environmentalism of the Reagan administration, and then the number of hearings increases to a high nearly matching that of the late 1970s. A backlash toward the land use policies of the Reagan administration, which led to the consideration of new environmental legislation, ${ }^{28}$ probably fueled the increase in the number of hearings during the latter part of the 1980s. The House held a greater proportion of the property hearings than the Senate during the 1980s, except for the period between 1983 and 1987 . The early part of the 1990s witness another decline in the number of hearings until 1993 when they increase again. Not surprisingly, this coincides with the beginning of the Clinton/Gore administration which heralded a new national commitment to the environment. The increase in property hearings

\footnotetext{
${ }^{28}$ Congress strengthened the Resource and Conservation Act in 1984, and enacted the Superfund Amendments and Reauthorization Act of 1986, the Safe Drinking Water Act of 1986, and the Clean Air Act of 1987.
} 
continues through the end of the study. Following 1987, the proportion of property hearings held in the House continued to increase over that of the Senate until 1993 when the fraction of hearings held in either chamber drew closer.

In sum, Figure 1 shows that the property issue has maintained a position on the government's agenda over the past three decades. Overall, the House has held most of the property hearings during the period of this study, with the exception of two notable periods 1969 to 1973 and 1983 to 1987 . In more recent years, the House has dominated over the Senate in the proportion of property hearings it has held.

\section{What's in a Property Hearing?}

The topic of each hearing was coded according to five categories: land use; creation and access to national parks, preserves, and areas; private property rights and compensation; right-ofway and easements; and, eminent domain. These categories correspond with the keywords and 'see also' references regarding property while searching the CIS reports for hearings. The validity of each hearing's categorization was checked by reading the hearing's title and/or the content of the hearing's abstract. Examples of hearings coded as land use were titled "Mineral Exploration and Development Act of 1991", and "Land Use and Resource Conservation". An example of a hearing coded as creation and access to national parks, preserves, and areas was titled "To Enlarge the Indiana Dunes National Lakeshore". An example of a hearing coded as private property rights was titled "Real Property Acquisition Practices and Adequacy of Compensation in Federal and Federally Assisted Programs". An example of a hearing coded rights-of-way and easements was titled "Right of Way Acquisition Practices in West Virginia". An example of a 
hearing coded eminent domain was titled "Coal Slurry Pipelines". Table 1 shows the number of hearings coded by each topic.

Table 1: Number of Property Hearings by Topic, 1959 - 1995

\begin{tabular}{ll}
\hline Topic & Frequency (\%) \\
\hline Land Use & $121(45.5)$ \\
\hline National parks, Preserves, and Areas & $97(36.5)$ \\
\hline Private Property Rights & $24(9.0)$ \\
\hline Right-of-way and Easements & $12(4.5)$ \\
\hline Eminent Domain & $12(4.5)$ \\
\hline Total & $266(100)$ \\
\hline
\end{tabular}

Table 1 indicates that Congress was most concerned with land use matters concerning property. These hearings, totaling 121, addressed a wide range of issues concerning the uses (e.g., recreational or commercial) of public lands. The second greatest number of property hearings (97) dealt with the creation and access to national parks, preserves, and areas. And, the third greatest number of property hearings (24) dealt with property rights and compensation. Hearings dealing with eminent domain (12) and rights-of-way and easements (12) make up the remainder of the hearings. The information in Table 1 is useful for describing the content of the property hearings. Yet, a more detailed consideration of the property hearings may be given when they are viewed over time. Figure 2 depicts the property hearings by topic as a proportion of the total property hearings from 1959 and 1995. This examination will enable me to determine what aspects of the property issue were salient in Congress and when, as well as determine the ebb and flow of the various issues as they move on and off the governmental agenda. 


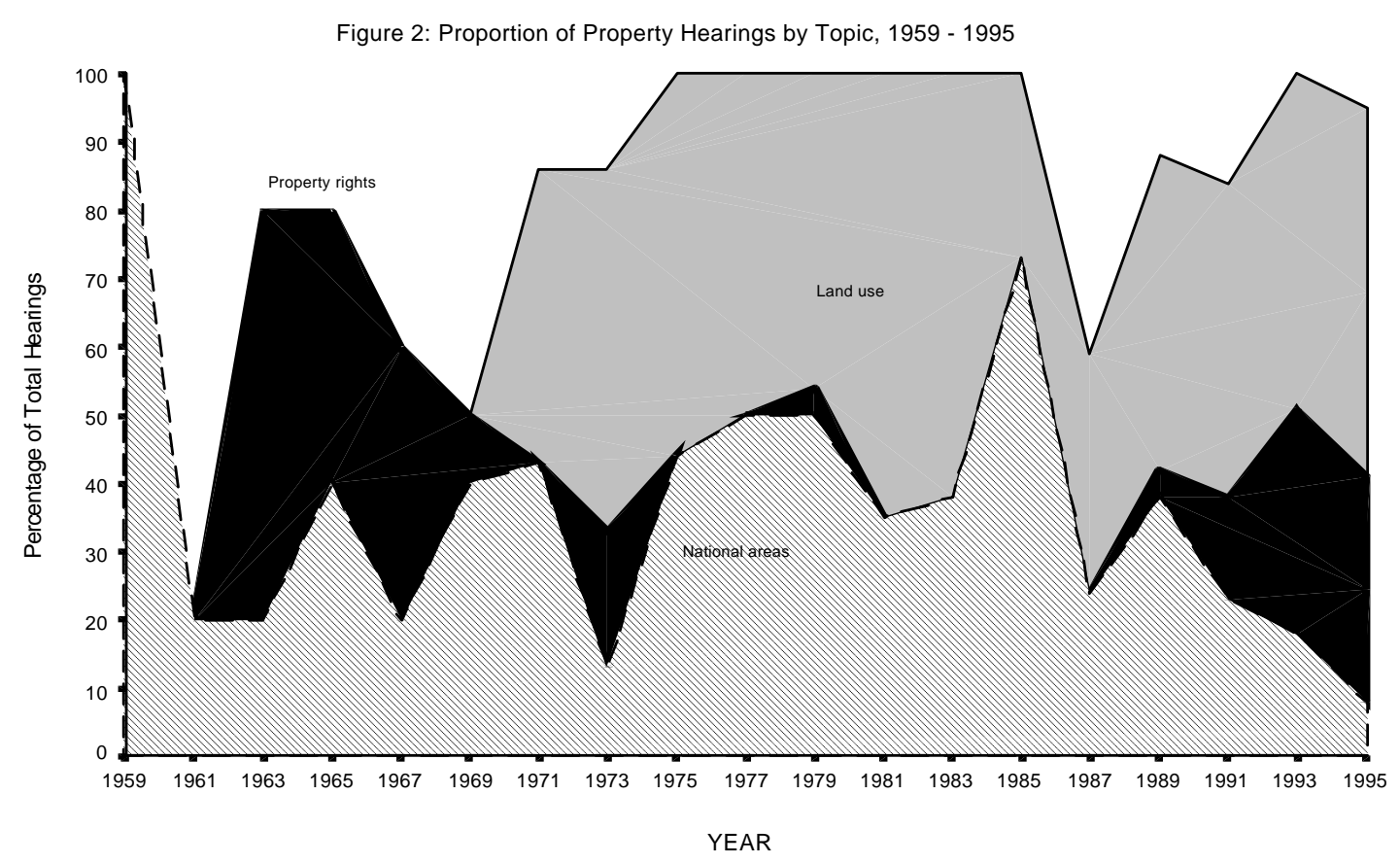

Figure 2 shows that during the early years of this study, 1961 - 1967, the property hearings in Congress mostly concerned property rights issues. The property rights hearings during these years deal primarily with the consequences of federal programs to property owners, such as the procedures of property acquisition. An example of a property rights hearing during the early years of this study is titled "Real Property Acquisition Practices and Adequacy of Compensation in Federal and Federally Assisted Programs," and "Summer House in the Stanislaus National Forest, Relief to Harriet C. Chambers, and Acceptance of Cash in Land Exchange Transactions.” After 1967, Congress becomes less interested in the property rights aspect of property matters and does not grant it serious consideration again until the early 1990s. 
In agenda setting language, the property rights issue essentially dropped of the governmental agenda during the 1970s and most of the 1980s, only to reappear again in the 1990s.

At the same time the proportion of property rights hearings is decreasing in the late 1960s, Congress begins to increasingly hold property hearings concerning national areas and land use. In fact, Congress was constantly considering issues of national areas between 1959 and 1995, although to varying degrees. Again, this type of hearing deals with the creation and access to national parks, preserves, and areas. Figure 2 shows that the proportion of property hearings concerning national areas is sporadic until 1975 when it stabilizes for several years then drops off in 1981. The 1970s also begin nearly two decades in which the property hearings in Congress were nearly dominated by land use issues. Again, these hearings deal with the recreational and commercial use of public lands. Land use hearings begin in 1969 and remain prominent throughout the end of the study. The high proportion of hearings concerning national areas and land use during the late 1970s is no surprise since this is a period of heightened environmental awareness and also the period when President Carter converted millions of acres of Bureau of Land Management lands into federal wilderness areas, national parks and wildlife refuges.

After 1985, the fraction of hearings concerning national areas and land use drop, only to be followed two years later by an increase in all the proportion of all three topics. Property hearings concerning national areas increase until 1989 when they fall off and continue to decrease through the end of the study. Yet, following 1987, the proportion of hearings dealing with property rights and land use follow a similar pattern of change. They both increase until 1989, experience a brief decrease in 1991, increase again until 1993, and drop off through 1995. The reappearance of property rights as a primary topic in property hearings indicates that 
the issue regained a position on the governmental agenda. What is also interesting to note is that with the resumption of the property rights debate, Congress was also discussing property rights differently. Whereas before the property rights hearings were dealing with issues of property acquisition and such, now the hearings were addressing the issue of regulatory takings. For instance, an example of a property rights hearings held in 1992 is entitled "Takings, Compensation, and Pending Wetlands Legislation," and a hearing in 1993 is entitled "Private Property Protection Act of 1993." Figure 2 provides evidence that the property rights issue is salient in Congress and holds a position on the governmental agenda. It also provides initial evidence supporting my claim that a Schattschneider mobilization occurred by showing that the property rights issue became a serious topic of concern in Congress after many years of considering primarily the issues of national areas and land use. Remember, a Schattschneider mobilization is a movement in reaction to governmental activity that opposes your goals and beliefs. As I discussed in Chapter three, many of government's policies affecting property created detrimental economic consequences for the private property owners and were often viewed as a violation of their civil rights. Therefore, I would expect the property rights issue to grow in salience as it is advocated by the property rights community. The following sections will study in great detail the existence of a Schattschneider mobilization.

\section{Testing for Mobilization}

A study of the tone of the hearings will enable me to test my claim that a Schattschneider mobilization occurred. In other words, I will be studying to see if Congress has increasingly noted the interests of the property rights community as a reaction to the seemingly growing 
environmental regulations sought after by the environmental movement. The tone of the hearings were coded either positive or negative from the perspective of the environmentalist. Those hearings addressing environmental protection, the merits of environmental laws, or the creation, expansion, or conservation of public lands were coded positive. Those hearings addressing economic issues (i.e., the negative economic effects of environmental laws and programs), the rights of private interests and/or individuals were coded negative. Some hearings were easily categorized as positive and negative by a reading of its title. An example of a hearing coded positive was titled "National Wildlife Refuges". Also, an example of a hearing coded negative was titled "Sagebrush Rebellion: Impact on Energy and Minerals". Other hearings could not be as easily identified as either positive or negative based upon its title. For example, a hearing titled "Public Lands and Management Policy" has no obvious bias. To reliably code such hearings, I read the hearing's abstract to be sure of its content. To ensure the reliability of my coding scheme, I began recoding the hearings or tone and after 10 years I found approximately 95 percent agreement between the two attempts at coding.

An increase in negatively toned hearings should indicate that Congress is considering the interests of the property owners, and that the property rights community has gained access to the governmental agenda. Figure 3 depicts the proportion of hearings coded negative from 1959 1995. 
Figure 3: Proportion of Property Hearings by Tone, $1959-1995$

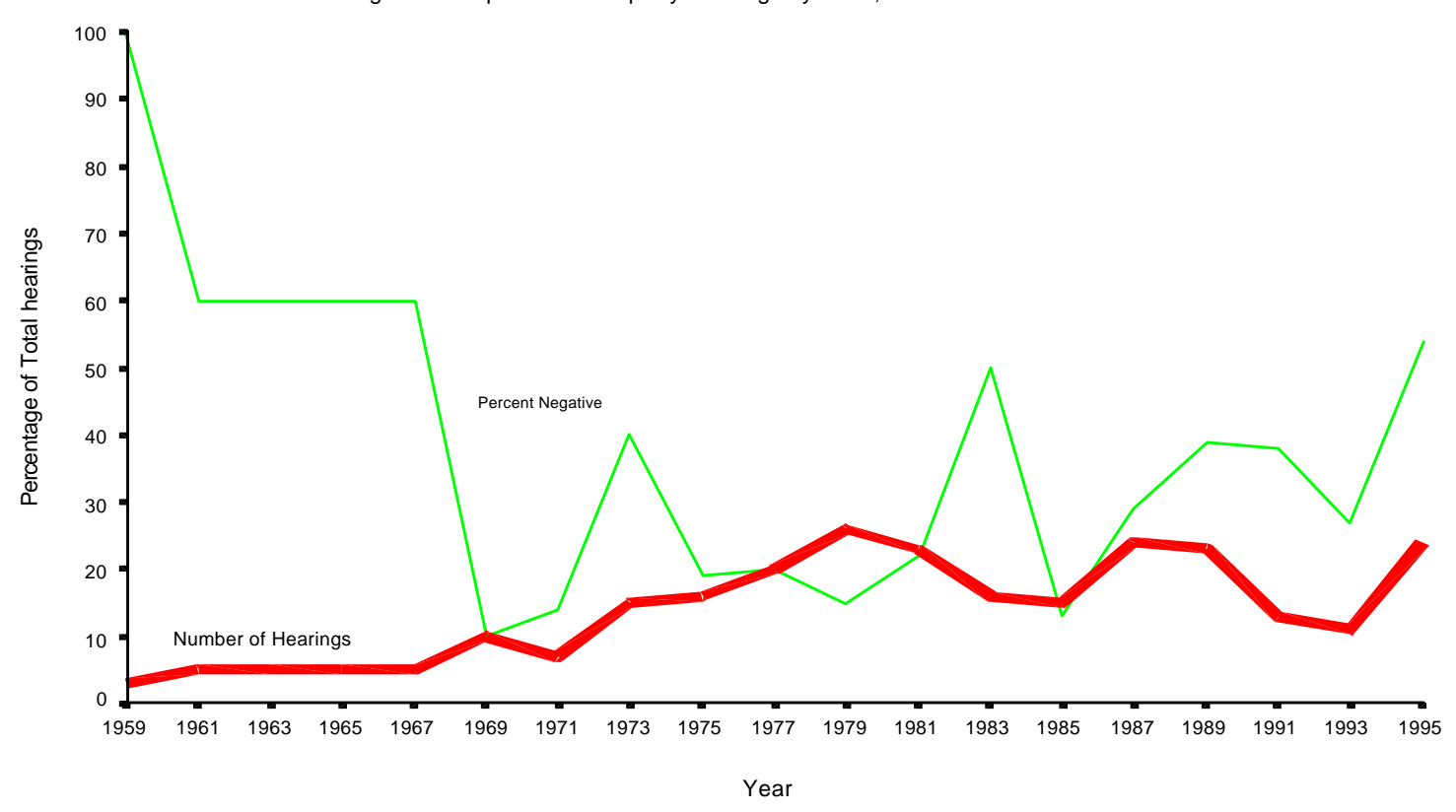

Early, the proportion of hearings coded negative was high. This is likely due in part because of the low number of hearings (no more than 5 through 1967) and because the environmental movement had not yet gained momentum. Then, around 1967 the proportion drops indicating that the property hearings in Congress began to favor environmental interests. This corresponds with the initial period of environmentalism which is characterized by heightened attention toward environmental issues. The proportion of property hearings coded negative during this period is low. Between 1969 and 1985, the proportion of negative coded hearings remain relatively stable, except for brief peaks in between 1971 to 1973 and between 1980 to 1983 . The increase in negatively toned hearings in the early 1980 s is likely due to the impact of the Reagan administration. Its antienvironmental agenda provided a favorable political 
atmosphere for the advocacy of private concerns (Vig 1997). After a short decline following 1983 , the tone of property hearings again became increasingly negative beginning in 1985 . This upward trend lasts until 1991, at which point the hearings begin to favor environmental interests. Yet, beginning in 1993 and through the end of my study there is a marked increase in the number of hearings coded negative. The newly won Republican majority in the House, which occurred in 1994, is the probable explanation for the final increase in hearings favoring the property rights community.

My findings provide evidence supporting my claim that Congress has begun considering the effects of environmental policy on the property owner. Indeed, these results are evidence that a Schattschneider mobilization occurred. Based on the data, it may be argued that this challenge for the agenda occurred twice. Once in the early 1980s, and again in the late 1980s (and the increase beginning in 1993 may be indication of the beginning of a third mobilization). That is, as the tone of property hearings increasingly favor the interests of the property rights community, I argue that this group has mobilized to challenge for influence over the governmental agenda.

Figure 3 also shows that beginning in 1985 the percentage of negative coded hearings (i.e., those hearings favoring the property rights community) increased as the number of hearings increased. This is precisely the pattern I expect to be associated with a Schattschneider mobilization. As discussed in chapter two, during a Schattschneider mobilization opponents seek to expand the issue to increase the number of participants in the conflict and the number of venues considering the problem in order to create policy change. Consequently, as more venues consider the problem, more hearings will be held. Therefore, one thing to look for when studying a Schattschneider mobilization is an increase in hearings concerning the issue. Finally, not only is 
this evidence of a Schattschneider mobilization, but Figure 3 also illustrates that this mobilization began around 1979 and continues through the last year of the study (except for a brief disruption between 1983 to 1985 and 1991 to 1993).

\section{Participating in the Mobilization}

For a deeper analysis of whether a Schattschneider mobilization occurred, I next studied the type of participants testifying in each property hearing. I expect to find an increasing number of participants representing the property rights community appearing in property hearings. This would lend support to my claim that the community has mobilized and is seeking an effective challenge to the governmental agenda. The participants were coded by reading the abstract of the witnesses' testimony at the hearing. I coded each witness into one of the following categories: property rights community (property rights and economic interest ); environmental interest; elected official; or, other and uncodeable. These categories correspond with the two dominate coalitions involved in this issue. In other words, those participants coded as the property rights community represent private interest, and those coded as environmental interest represent the environmental movement. A second coding of the hearings resulted in a 95 percent agreement between the two attempts.

I found the majority of the participants to be members of the numerous groups on both sides of the battle. As expected, a significant number of witnesses testifying in favor of property rights were individual landowners and members of groups representing resource intensive industries, such as timber and coal. There was also a notable presence by area Chamber of Commerces and utility interests. Members of environmental groups, such as the Nature 
Conservancy and the Audubon Society, made up a substantial portion of the witnesses testifying against property rights. Also, there was a fair number of elected officials (members of Congress and state and local government officials) testifying. Figure 4 tracks the involvement of witnesses by type in property hearings as they appear in all committees and in both chambers from 1959 to 1995.

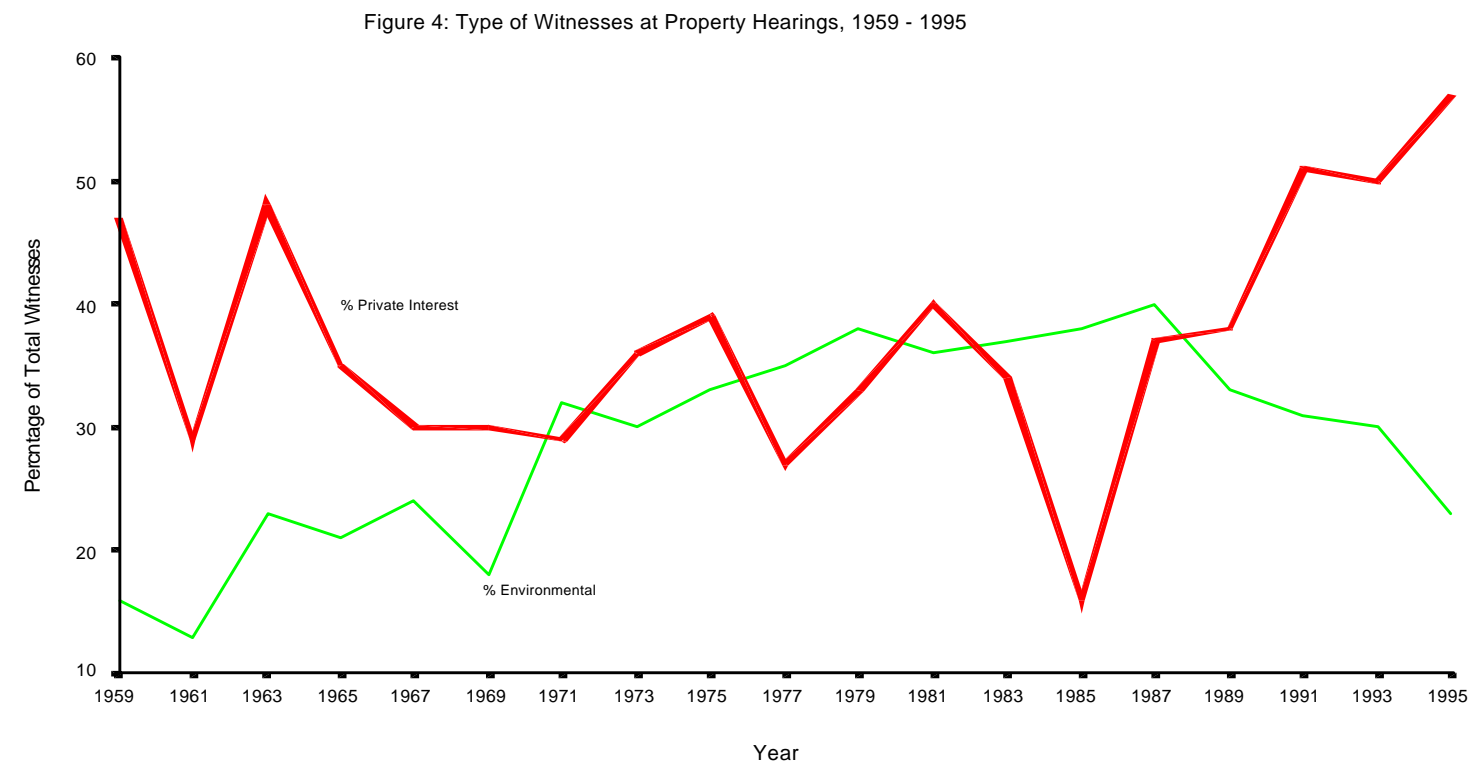

Figure 4 provides additional evidence that the property rights community has gained increased access into the policymaking process regarding property. The proportion of environmental witnesses at property hearings increased during the 1970s and through the late 1980s. This is no surprise given the euphoria surrounding environmentalism and the consistent favorable public opinion granted environmental issues during these years (Switzer 1994; Rosenbaum 1998). However, after 1987, the involvement of environmental witnesses shows a 
steady rate of decline, thus suggesting a waning degree of access and participation in the policymaking process.

The involvement of private interest witnesses follows a wholly different pattern. From 1965 to 1971 they maintain a relatively stable presence at property hearings. Then from 1971 to 1975 their presence increases and even exceeds that of the environmentalists. The rise in the number of private interest witnesses during this period coincides with the growing proportion of property hearings held in favor of the property rights community (see Figure 3). The proportion of private interest witnesses escalates again from 1977 to 1981 . This may be a result of the oil embargo the country endured in the late 1970s. That is, as the country faced a shortage of energy supply, perhaps an increasing number of representatives from resource industries, such as coal and natural gas, were being invited to appear before Congress to discuss policy alternatives. The proportion of private interests drastically decreases from 1981 to 1985 . This is a surprising finding. I would have expected to find their proportions increase during these years since the Reagan administration's pro-development approach to resource management created a 'policy window' enabling members of the property rights community to advocate their interests. Yet, from 1985 to the end of my study the proportion of private interest witnesses at property hearings increases significantly. Again, the rise in the proportion of private interest witnesses in 1985 coincides with the growing proportion of hearings being held that pertain to the interests of the property rights community during this time (see figure 3). Also, the increase is likely driven by the policy consequences developing out of the environmental laws of the past three decades which have incited an intensified involvement by the property rights community. The consistent increase in their participation following 1985 is further evidence that the property rights 
community has successfully challenged for access into the legislative process surrounding property matters. Therefore, the Schattschneider mobilization that I claim occurred seems to be accurate and in all probability continuing today. To sum up, Figure 4 reveals that over the period of this study the property rights community has maintained a presence in property hearings, and since 1987 have dominated involvement in such hearings.

\section{Jurisdictional Control}

Next, it is important that I determine which committees are holding property hearings. As stated, different venues present not only different images, but also favor particular groups (Baumgartner and Jones 1993; Worsham 1998). The choice of venue, then, often determines which groups will influence the policy outcomes, the manner in which the issue is framed, and the nature of the public policy produced (Baumgartner, Jones, and Rosenstiehl 1997; Worsham 1998). Therefore, the committee holding the property hearing matters greatly. A study of the committees will reveal whether jurisdictional control existed that may have contributed to denying the property rights community agenda access. Furthermore, it will indicate whether the property rights community had incentive to shift venues to the states. I counted the number of property hearings in each committee and in both chambers of Congress. I then coded the committees holding property hearings as either an environmental or property rights committee. Briefly, I considered environmental committees those which have environmental responsibilities and which traditionally favor environmental interests. ${ }^{28}$ Conversely, property rights committees

\footnotetext{
${ }^{28}$ Information on the environmental policy responsibilities of Congressional committees was taken from Table 1-1 "Major Congressional Committees with Environmental Responsibilities" in Norman Vig and Michael Kraft's, 1997, Environmental Policy in the 1990s: 3rd. ed. Washington, D.C.: CQ Press.
} 
are those that, among other things, favor commerce, development, and agriculture interests.

Table 2 reports the number of property hearings held in each Congressional committee and by which type of committee.

Table 2: Number of Property Hearings by Congressional Venue, 1959 - 1995

\begin{tabular}{|c|c|}
\hline Venue & \# of Hearings (\% of total) \\
\hline \multicolumn{2}{|l|}{ House Environmental Committees } \\
\hline Resources (formerly Natural Resources and Interior and Insular Affairs) & $85(59 \%)$ \\
\hline Transportation and Infrastructure (formerly Public Works and Transportation) & $14(10 \%)$ \\
\hline Total (\% of total House property hearings) & $99(68 \%)$ \\
\hline \multicolumn{2}{|l|}{$\underline{\text { House Property Rights Committees }}$} \\
\hline Agriculture & $22(15 \%)$ \\
\hline Merchant Marine and Fisheries & $14(10 \%)$ \\
\hline Interstate and Foreign Commerce & $3(2 \%)$ \\
\hline Judiciary & $3(2 \%)$ \\
\hline Commerce (formerly Energy and Commerce) & $2(1 \%)$ \\
\hline Small Business & $1(.05 \%)$ \\
\hline Science (formerly Science, Space, and Technology) & $1(.05 \%)$ \\
\hline Total (\% of total House property hearings) & $46(32 \%)$ \\
\hline \multicolumn{2}{|l|}{ Senate Environmental Committees } \\
\hline Energy and Natural Resources (formerly Interior and Insular Affairs) & $91(79 \%)$ \\
\hline Environment and Public Works & $13(11 \%)$ \\
\hline Total ( $\%$ of total Senate property hearings) & $104(90 \%)$ \\
\hline \multicolumn{2}{|l|}{$\underline{\text { Senate Property Rights Committees }}$} \\
\hline Commerce, Science, and Transportation & $6(5 \%)$ \\
\hline Agriculture, Nutrition, and Forestry & $3(3 \%)$ \\
\hline Small Business & $1(1 \%)$ \\
\hline Judiciary & $1(1 \%)$ \\
\hline Total (\%o of total Senate pronerty hearings) & $11(10 \%)$ \\
\hline
\end{tabular}

Table 2 suggests that environmental committees dominated the hearings concerning property. I found that environmental committees held 68 percent of the property hearings held in the House. The Resources committee held 59 percent of the total hearings on property matters in 
the House, which is a far greater proportion than any other House committee. In the Senate there was greater domination in that environmental committees held 90 percent of the property hearings. The Energy and Natural Resources committee held 79 percent of the total property hearings in the Senate, which represents a near complete domination of property hearings. These results indicate that property hearings in the House and the Senate were controlled by committees that traditionally favor environmental interests. Moreover, these findings support my theory that the jurisdictional control exercised by the environmental committee(s) prevented the property rights community from realizing legislative success. I also argue that this jurisdictional domination may have given the community the incentive to shift venues to the states.

Next I will track the jurisdictional control evidenced in the preceding section over the period of my study to determine when it began and whether it currently exists. This will tell me whether the mobilization of the property rights community resulted in more property hearings being held in favorable committees. My earlier findings suggests that a Schattschneider mobilization occurred twice between 1959 and 1995 (see Figure 3 and 4), therefore I expect to find that the property rights committees were holding hearings during these periods in the attempt to gain jurisdictional control and challenge for control over the political agenda over the property issue. Figures 5 and 6 depict the proportion of property hearings held in the House and Senate committees by type, respectively, from 1959 - 1995. 
Figure 5:Property Hearings by House Committee Type, 1959 - 1995

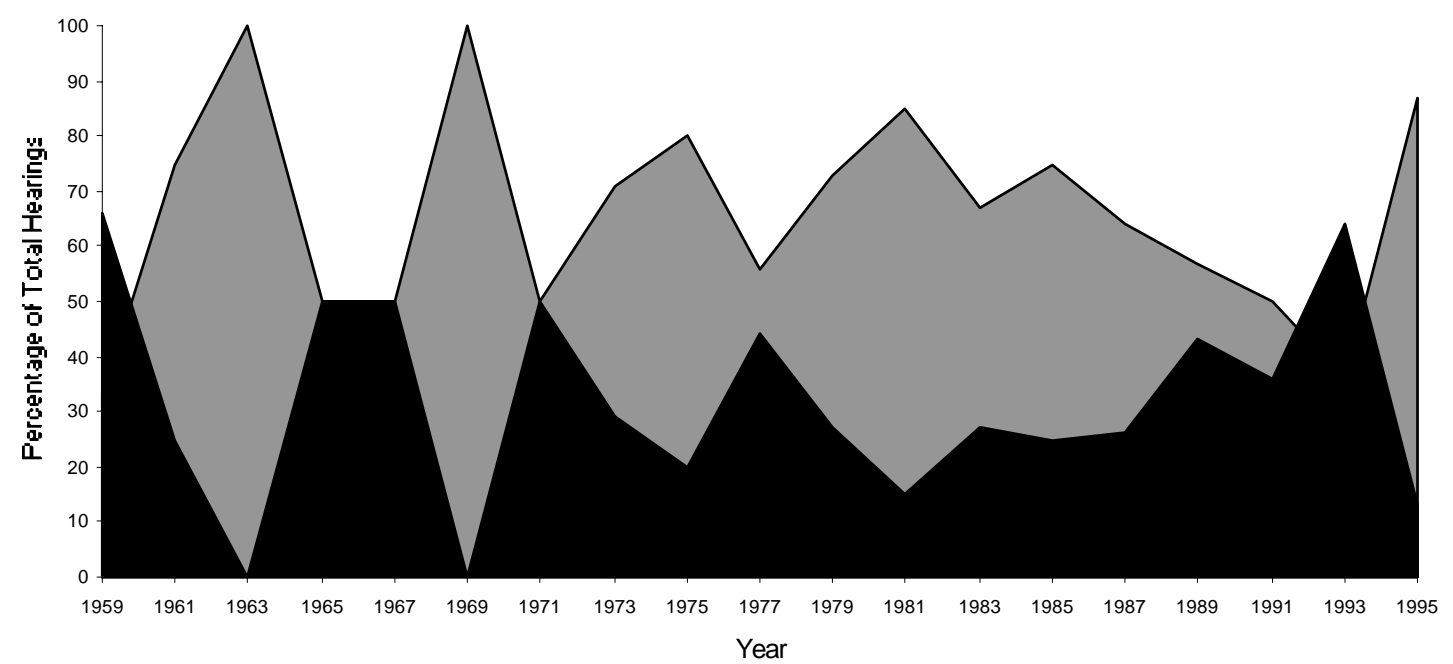

$\square$ Environmental Committees $\boldsymbol{\square}$ Property Rights Committees

The results of Figure 5 imply that jurisdictional control in the House is subject to change. My findings show that in several different occasions property rights committees challenged for jurisdictional control over the property issue. Up to 1967, there were few property hearings held in the House (no more than 3 between the two committee types) making it difficult to reliably judge for jurisdictional control. Yet, during the 1970s the number of property hearings increase, and the proportion held in property rights committees is sporadic. First, there is an increase in the proportion of property hearings held in property rights committees beginning in 1969 and lasting until 1971. This corresponds with an increase in hearings coded in favor of the property rights community (see Figure 3) and with an increase in the proportion of witnesses representing the 
property rights community participating in property hearings (see Figure 4). Second, there is an increase in the fraction of hearings held in property rights committees from 1975 to 1977 . This also corresponds with an increase in the proportion of witnesses representing the property rights community and appearing in property hearings beginning in 1977 (see Figure 4). Third, there is a sustained increase in the proportion of hearings held in property rights committees beginning in 1981 and lasting until 1993. Again, this increase corresponds with an increase in property hearings coded in favor of the property rights community beginning in 1985 (see Figure 3) and a drastic increase in the proportion of witnesses representing the property rights community and testifying in property hearings during this time. For a brief period from 1991 to 1993, there are more hearings held in property rights committees than in environmental committees in the House.

Figure 5 illustrates the malleability of jurisdictional control in the House. Several times throughout the study, jurisdiction control over property proved to be wavering between the two committee types. Surprisingly, for a brief period in the early 1990s, the property rights committees were holding more property hearings than the environmental committees. Yet, overall, the environmental committees maintained control over matters concerning property. This important finding supports of my argument that institutional control helped prevent the property rights community from gaining significant influence over the policymaking decisions regarding property. 
Figure 6: Property Hearings by Senate Co m mittee Type, 1959 - 1995

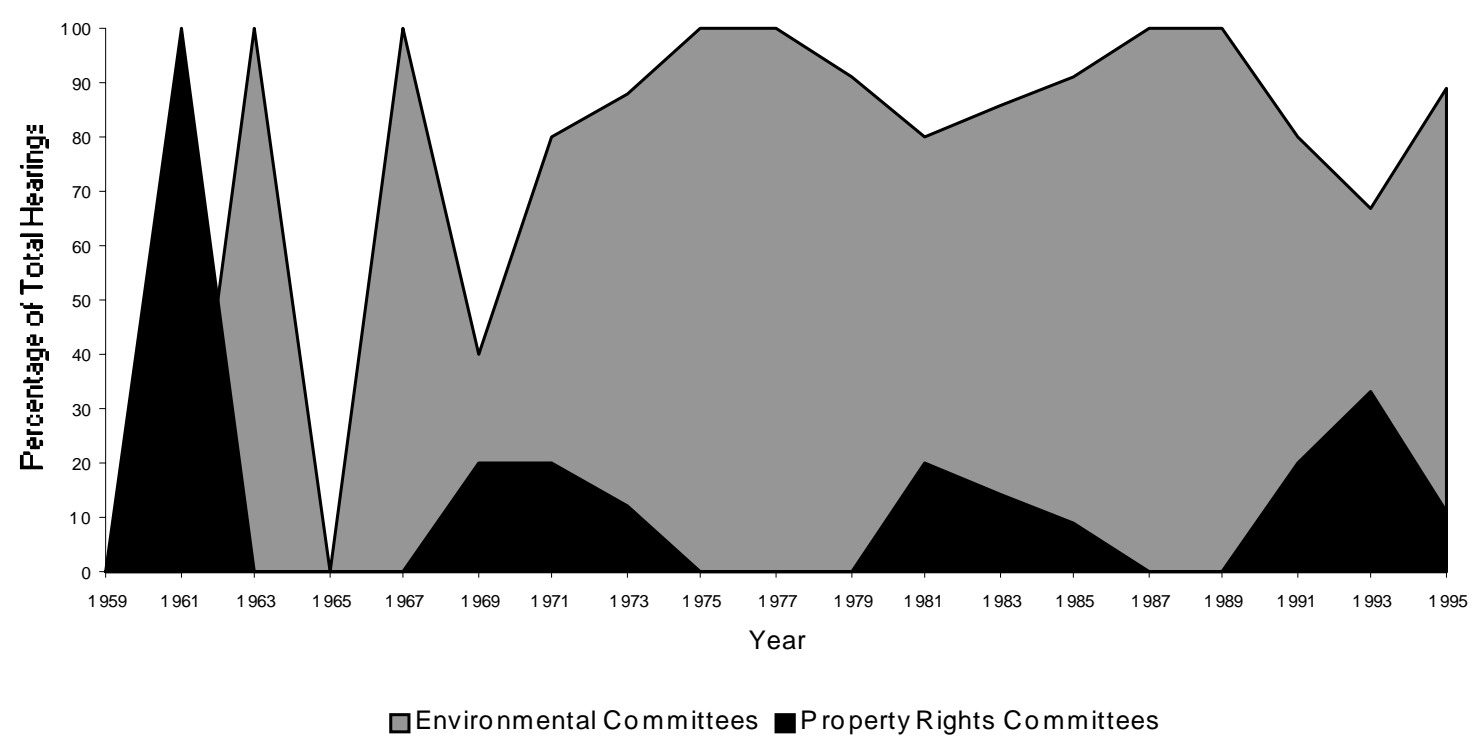

Figure 6 reveals an even greater jurisdictional dominance in the Senate. From 1969 to 1995, the proportion of property hearings held in Senate environmental committees is much greater than that held in property rights committees. The jurisdiction control evidenced between 1969 and 1977 coincides with the early years if the environmental movement marked by heightened attention and public awareness. Then, still dominating jurisdictional control, the proportion of property hearings fluctuates in the Senate environmental committees from the late 1970s until 1993, when a notable increase is evidenced. This suggests that the environmental committees monopolized hearings concerning property throughout the entire period of my study. Conversely, only a relatively small fraction of property hearings were held in property rights committees during the years of my study (excluding the years prior to 1967 where no more than 2 
property hearings were held between the two committee types). In fact, there is little evidence that the institutional control exhibited by the environmental committees is even challenged from 1969 to 1995 . Thus, I am able to conclude that, as in the House, the Senate environmental committees maintained institutional control over property issues. Also, as in the House, these findings support the hypothesis that institutional control helped deny the property rights community policymaking influence.

In sum, the preceding sections have shown that property hearings, including those dealing with property rights and compensation, have for the most part been held in committees which traditionally favor environmental interests. These results support the claim that, despite the increased access of the property rights community into the policymaking process, the jurisdictional control exhibited by environment committees has impeded the property rights community's success at getting property rights legislation passed.

\section{Participation in Committees}

I next want to see if the committees favor certain groups. This is an important determination. If it is shown that the environmental committees favored environmental witnesses, and effectively shut the property rights witnesses out of the decision making process, then jurisdictional control played a greater role in denying the property rights community agenda access. In turn, this strengthens my claim that the property rights community had to seek other venues to lodge their concerns. Table 3 reports the average proportion of witnesses by type participating in the House and the Senate property hearings from 1959 to 1995. 
Table 3: Nature of Witnesses in Property Hearings by Congressional Venue, 1959 - 1995

\begin{tabular}{|c|c|c|}
\hline Venue & $\begin{array}{c}\% \text { Property Rights } \\
\text { Community }\end{array}$ & \% Environmental \\
\hline \multicolumn{3}{|l|}{$\underline{\text { House Environmental Committees }}$} \\
\hline Resources (formerly Natural Resources and Interior and Insular Affairs) & 43 & 34 \\
\hline Transportation and Infrastructure (formerly Public Works and Transportation) & 38 & 14 \\
\hline \multicolumn{3}{|l|}{$\underline{\text { House Property Rights Committees }}$} \\
\hline Agriculture & 38 & 27 \\
\hline Merchant Marine and Fisheries & 25 & 49 \\
\hline Interstate and Foreign Commerce & 36 & 31 \\
\hline Judiciary & 44 & 3 \\
\hline Commerce (formerly Energy and Commerce) & 94 & 6 \\
\hline Small Business & 50 & 50 \\
\hline Science (formerly Science, Space, and Technology) & 50 & 0 \\
\hline \multicolumn{3}{|l|}{$\underline{\text { Senate Environmental Committees }}$} \\
\hline Energy and Natural Resources (formerly Interior and Insular Affairs) & 33 & 30 \\
\hline Environment and Public Works & 32 & 39 \\
\hline \multicolumn{3}{|l|}{$\underline{\text { Senate Property Rights Committees }}$} \\
\hline Commerce, Science, and Transportation & 67 & 11 \\
\hline Agriculture, Nutrition, and Forestry & 51 & 36 \\
\hline Small Business & 57 & 36 \\
\hline Indiciary & 58 & 3 \\
\hline
\end{tabular}

The results of Table 3 are not expected. It is logical to think that the environmental committees would host more environmental witnesses that those representing the property rights community. Yet surprisingly, I found that, on average, there were more witnesses from the property rights community appearing in property hearings before the two dominate environmental committees. In property hearings in the House Resources committee, on average 43 percent of the witnesses represented the property rights community and 34 percent represented environmental interests. In property hearings in the Senate Energy and Natural Resources committee, on average 33 percent of the witnesses represented the property rights community 
and 30 percent represented environmental interests. Overall, witnesses representing the property rights community dominated participation in all House committees except for Merchant Marine and Fisheries, and all Senate committees except for Environment and Public Works. This suggests that Congress and legislators were considering the private and economic interests of those affected by legislation effecting property. These results seem to contradict the institutional control argument. That is, finding that the property rights community has gained access to the policymaking surrounding property matters in Congressional committees implies that jurisdictional control did not prevent access and the potential to influence policy. Moreover, the results of this study substantiate the claim that the property rights community has successfully challenged for control over the environmental agenda in this policy area. Yet, this evidence of access makes the fact that they have not realized legislative success even more curious.

Next, I will track the participation of the property rights community in environmental committees over time to reveal the degree in which their participation has been felt throughout the years. This study will contribute to determining if the jurisdictional control exercised by the environmental committees was instrumental in preventing the property rights community access to the policymaking process. Moreover, if periods of high participation in environmental committees is detected it may be argued that these are times when the community staged mobilizations in the attempt to capture the political agenda.

Figure 7 and Figure 8 tracks the proportion of environmental and property rights witnesses at property hearings held by the environmental committees of the House and Senate from 1959 to 1995 . Figures 7 and 8 indicate the degree to which the environmental committees favored either the environmental interests or those representing the property rights community in 
a given year. Also, they provide evidence of access to the decisionmaking process by either group.

Figure 7: Nature of Witnesses in Property Hearings Held by House Environmental Committees, 1959 - 1995

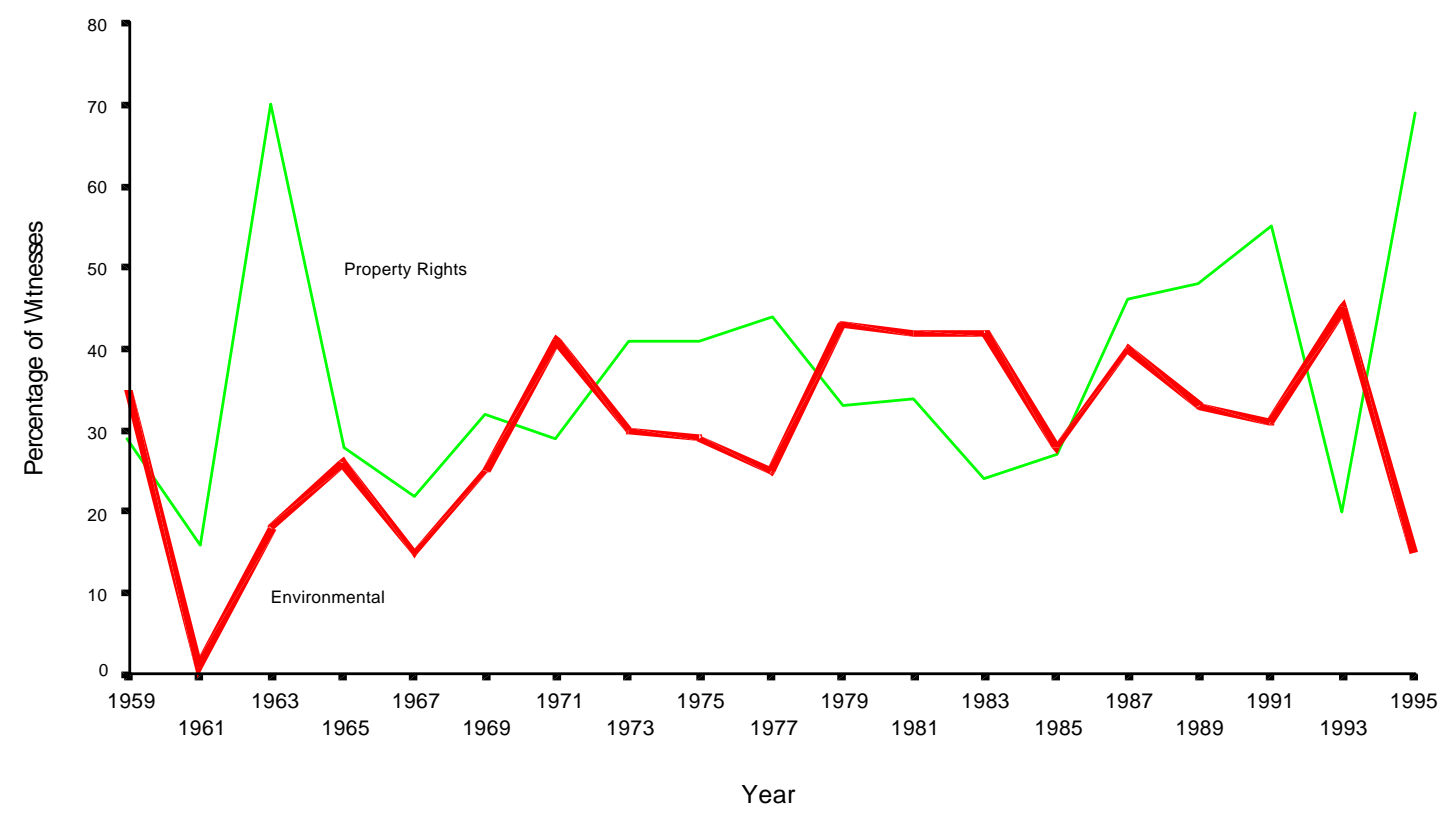


Figure 8: Nature of Witnesses in Property Hearings Held by

Senate Environmental Committees, 1959 - 1995

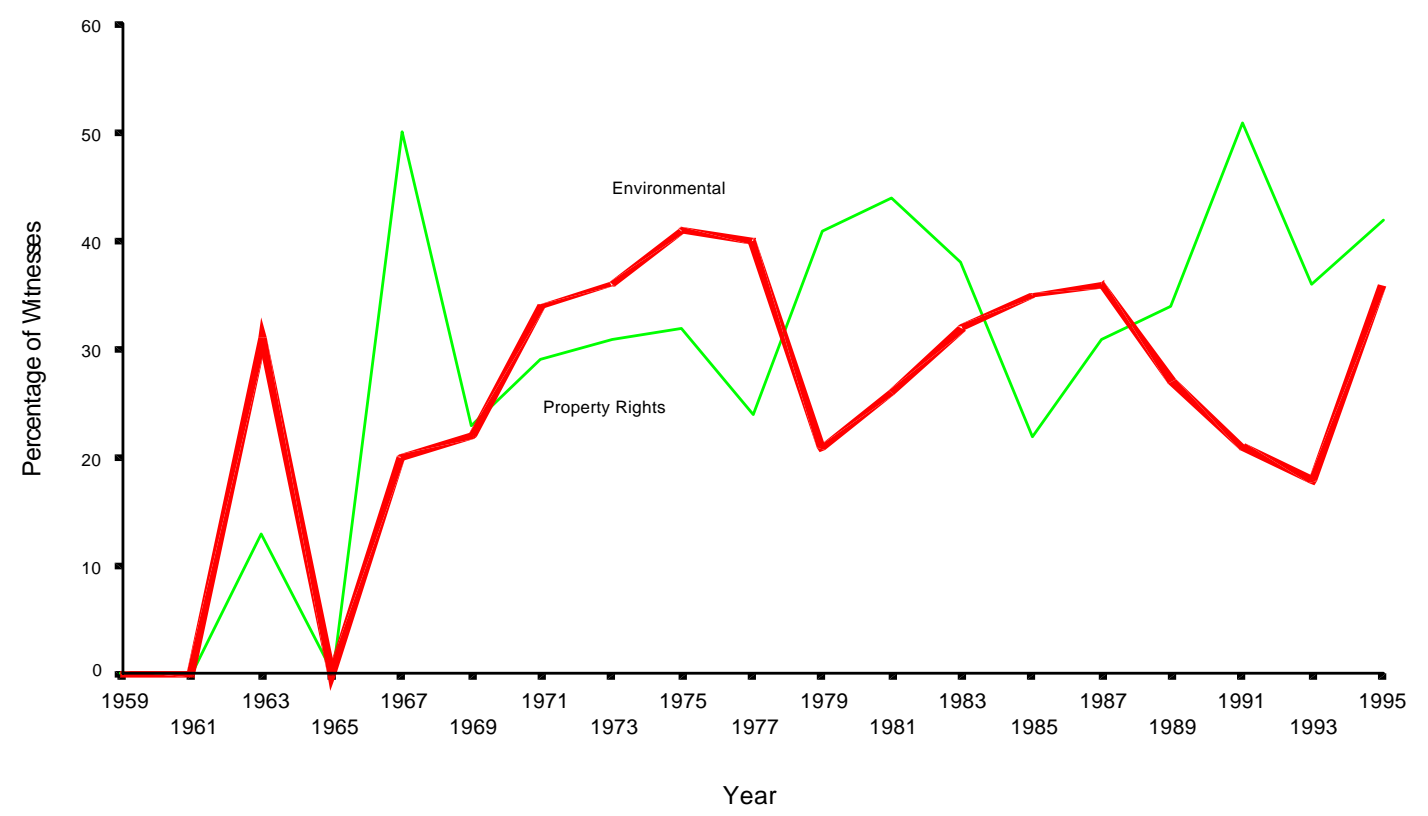

The results of Figure 7 and Figure 8 are surprising. During my study, there is no evidence that the environmental committees favored a particular group to the exclusion of the other. Figure 7 illustrates that, before 1967, the environmental committees hosted more property rights witnesses in property hearings. Perhaps, participation by environmental witnesses was relatively low at this time because the environmental movement had yet gained momentum and it did not contain many groups and members. Then from 1967 to 1993, the degree to which both types of witnesses participated in property hearings in environmental committees fluctuates. During this time, the witnesses seemed to alternate dominance in the environmental committees on a cycle of approximately every six to eight years. Then, following 1993, there is a sharp increase in the proportion of property rights witnesses in environmental committees. During this time, a number 
of property rights laws were introduced in the House (see Appendix 1) which likely explains the increased participation in environmental committees.

Similar results were found in the Senate environmental committees, as shown in Figure 8. As in the House, I did not expect to find a substantial degree of participation by property rights witnesses. Up to 1969 , there is an erratic pattern of participation by both witness types. Then from 1969 to 1995 , Figure 8 reveals a relatively systematic pattern of participation where the two groups alternate dominance in the Senate property hearings held in environmental committees.

Figures 7 and 8 reveal some interesting points. The property hearings held in the environmental committees of both the House and the Senate were not dominated by witnesses solely concerned with environmental interests. Instead, for most of the years of my study, the property rights community had some degree of access to property hearings in environmental committees. Therefore, the jurisdictional control exercised by the environmental committees did not prevent the property rights community from gaining access to their venues.

My research makes several points clear. The property rights community has gained access to the policymaking surrounding property. My argument of acquired access is supported by the evidence produced in this section, as well as the previous sections studying participation. Furthermore, it is reasonable to argue that this access has led to a greater influence by the property rights community over the policymaking process surrounding property because the tone of the property hearings have increasingly favored their interests. Another point made clear by this research is that the environmental committees have exercised jurisdictional control over the property issue, which may explain why the property rights community has failed to get any substantial takings legislation passed through Congress, and therefore sought to shift the battle to 
the states. In the end, the results of my analyses substantiate the claim that the property rights community has successfully challenged for control of the environmental agenda in this policy area. I am left with the question of why the property rights community sought to shift venues to the state legislatures when they had gained access in Congress?

\section{Nonlegislative Hearings and Committee Jurisdictions}

In this section I will study the impact that nonlegislative hearings have had on the legislative process surrounding property issues. My study closely duplicates that of Talbert, Jones, and Baumgartner (1995) to better understand the impact of nonlegislative hearings and to test their claim that they are an important means by which entrepreneurial chairs frame issues in new ways favorable to future jurisdictional claims.

In both legislative and nonlegislative hearings, the planning for witness testimony is usually rigidly controlled, typically under the direction of the committee chair (Talbert, Jones, and Baumgartner 1995). Table 4 and Table 5 show which type of witnesses were invited to testify before which House and Senate committees, in both legislative and nonlegislative hearings. Based on the claims of Talbert, Jones, and Baumgartner (1995), I would expect to find a greater degree of bias in nonlegislative hearings than in legislative hearings. That is, I would expect to find that, in nonlegislative hearings, environmental committees were home to a greater proportion of environmental witnesses than witnesses representing the property rights community. Yet, the data in Table 4 and Table 5 do not indicate that this is the case. Based on the over 3600 applicable witnesses coded for the property issue, the bias found in nonlegislative hearings appears to favor the rival interests. 
Table 4. Congressional Testimony on Property before House Environmental Committees versus Testimony before House Property Right Committees, 1959 - 1996.

\section{A. House Legislative Hearings}

\section{Type of Witnesses Testifying}

\begin{tabular}{lccc}
\hline \multicolumn{1}{c}{ Venue } & Environmental & Property Right Community & Total \\
\hline Environmental Committees & 50 & 50 & $100(1586)$ \\
Property Right Committees & 41 & 59 & $100(397)$ \\
\hline \hline Total & 48 & 52 & $100(1983)$ \\
\hline
\end{tabular}

Gamma $=.17$; Chi-squared $(1$ d.f. $)=9.54(\mathrm{p}<.01)$

\section{B. House Non-Legislative Hearings}

Type of Witnesses Testifying

\begin{tabular}{lccc}
\hline \multicolumn{1}{c}{ Venue } & Environmental & Property Right Community & Total \\
\hline Environmental Committees & 38 & 62 & $100(255)$ \\
Property Right Committees & 36 & 64 & $100(72)$ \\
\hline \hline Total & 37 & 63 & $100(327)$ \\
\hline
\end{tabular}

Gamma $=.03$; Chi-squared (1 d.f. $)=.03(\mathrm{p}<.90)$

Note: N's reported in these tables refer to witnesses, not hearings. Witnesses coded as other and uncodeable are not included in the tables. There were 124 legislative hearings and 24 non-legislative hearings on property during this period. Hearings held in "other" committees are not included in this table. 
Table 5. Congressional Testimony on Property before Senate Environmental Committees versus Testimony before Senate Property Right Committees, 1959 - 1996.

\section{A. Senate Legislative Hearings}

\section{Type of Witnesses Testifying}

\begin{tabular}{lccc}
\hline \multicolumn{1}{c}{ Venue } & Environmental & Property Right Community & Total \\
\hline Environmental Committees & 51 & 49 & $100(1074)$ \\
Property Right Committees & 19 & 81 & $100(73)$ \\
\hline \hline Total & 49 & 51 & $100(1147)$ \\
\hline
\end{tabular}

Gamma $=.62 ;$ Chi-squared $(1$ d.f. $)=29.13(\mathrm{p}<.001)$

\section{B. Senate Non-Legislative Hearings}

Type of Witnesses Testifying

\begin{tabular}{lccc}
\hline \multicolumn{1}{c}{ Venue } & Environmental & Property Right Community & Total \\
\hline Environmental Committees & 40 & 60 & $100(202)$ \\
Property Right Committees & 38 & 62 & $100(24)$ \\
\hline \hline Total & 40 & 60 & $100(226)$ \\
\hline
\end{tabular}

Gamma $=.05 ;$ Chi-squared (1 d.f. $)=.11(\mathrm{p}<.80)$

Note: N's reported in these tables refer to witnesses, not hearings. Witnesses coded as other and uncodeable are not included in the tables. There were 100 legislative hearings and 18 non-legislative hearings on property during this period. Hearings held in "other" committees are not included in this table. 
Table 4 shows that House environmental committees considering legislation on property invited an equal proportion of witnesses to testify in the hearings. That is, 50 percent of the witnesses represented environmental interests and 50 percent represented the interests of the property rights community. Table 5 shows that the Senate environmental committees considering legislation on property acted very similar. 51 percent of the witnesses represented environmental interests and 49 percent represented the interests of the property rights community. In nonlegislative hearings, there was a greater bias in the environmental committees as to who they invited to testify, yet in a surprisingly opposite proportion as would be expected. Table 4 shows that only 38 percent of the witnesses testifying before environmental committees represented environmental interests, whereas 62 percent represented the property rights community. Table 5 shows that in Senate nonlegislative hearings, like in the House, the bias found was in an opposite proportion as would be expected. Only 40 percent of the witnesses testifying before environmental committees represented environmental interests, whereas 60 percent represented the property rights community. These findings are interesting because they refute the claim of Talbert, Jones, and Baumgartner (1995) that committee chairs use nonlegislative hearings to promote certain views of their issues to foster their abilities to produce favorable legislation. My findings indicate that the nonlegislative hearings held by environmental committees in both chambers were not used in this fashion. If anything, they were a forum whereby the property rights interests were allowed representation and the opportunity to express their views in the probable attempt to redefine the property issue. It may be the case that environmental committees invited more rival witnesses to nonlegislative hearings because they did not want them appearing in hearings that were considering legislation and, thus, where they could effect the type of policy 
discussed in such hearings. This is a sensible explanation except for the finding that representatives of the property rights community were testifying in equal proportions in legislative hearings before environmental committees. Therefore, it seems that environmental committee leaders were unable to prevent the participation of their rivals no matter what type of hearing was being held.

In the House property rights committees, I found a greater tendency to invite those with whom one already agrees. Table 4 reports that 59 percent of those testifying before House property rights committees considering legislation on property were witnesses representing the property rights community. In nonlegislative hearings, 64 percent of the witnesses represented the interests of the property rights community. Table 5 indicates that Senate property rights committees, as in the House, were more likely to invite "friendly" witnesses to testify before property hearings. 81 percent of those testifying before Senate property rights committees considering legislation on property were witnesses representing the property rights community. In nonlegislative hearings, 62 percent of the witnesses represented the interests of the property rights community. These findings agree with the claim of Talbert, Jones, and Baumgartner (1995) that the nonlegislative hearings were home to a greater degree of bias than legislative hearings.

Overall, Table 4 and Table 5 illustrate that legislative hearings tend to be more balanced than nonlegislative hearings. There is probably greater pressure to allow dissenters to speak in hearings considering actual legislation (Talbert, Jones, and Baumgartner 1995). Also, the tables show that there is no substantial inter-chamber differences between the House and the Senate in who they invite to testify, except in the legislative hearings before Senate property rights 
committees. The gamma statistic of .17 reported for House legislative hearings indicates a low level of association between the committee holding the hearing and the type of witness participating in the hearing (see Table 4). Given the even proportion of witnesses testifying in environmental committees, the gamma score most likely corresponds to the bias exhibited by the property rights committees to invite a greater proportion of "friendly" witnesses to their hearings. The gamma statistic of .62 reported for the Senate legislative hearings indicates a moderately strong level of association between the committee holding the hearing and the type of witness participating in the hearing (see Table 5). The higher gamma score for the Senate legislative hearings is likely influenced by the much greater proportion of property rights witnesses $(81 \%)$ than environmental witnesses (19\%) testifying before property right committees (see Table 5).

The gamma statistic of .03 reported for House nonlegislative hearings (see Table 4) and .05 for Senate nonlegislative hearings (see Table 5) indicates an extremely low level of association between the committee holding the hearing and the type of witness participating in the hearing. The very low gamma scores may be expected given the unexpected inverse relationship found in the environmental committees. That is, since finding that property rights witnesses dominated nonlegislative hearings in environmental committees in both chambers, I would expect this statistical test of association to be very small.

My study of nonlegislative hearings provides some new insights into their use by committee chairs. I found that the list of witnesses in nonlegislative hearings were indeed stacked, but not as previous studies have reported. Instead of environmental committee leaders saturating their hearings with like-minded witnesses to ensure that a certain viewpoint is heard, I found that the nonlegislative hearings were a forum for the rival interests to argue their case 
concerning property matters. Perhaps, the chairs of the environmental committees were inviting rival witnesses to participate in the nonlegislative hearings in the attempt to demonstrate their objectivity on the issue. In this light, nonlegislative hearings allow rival interests to infiltrate the oversight and investigative proceedings and inform the committees of the different aspects of the property issue. This may in turn influence those committees having jurisdiction over property matters to address dimensions of the issue previously ignored. In a sense, the representatives of the property rights community testifying in the nonlegislative hearings before environmental committees are "missionary" witnesses. They are attempting to inform the uninformed, convert the nonbelievers, and build government support for their interest. Once the rival interests establish a presence in the hearings they are in a position to influence the political agenda regarding the issue, and effect the formulation of any consequent legislation. Table 4 and Table 5 make one point clear. The representatives of the property rights community were active in all the hearings, regardless of the hearing and committee type.

\section{Discussion}

The preceding research have produced some interesting insights. First, property rights is a salient issue in Congress. The large proportion of recent hearings concerning property rights suggests that the issue maintains a position on the governmental agenda. Second, the property rights community has successfully gained access to the policymaking process in Congress, and on more than one occasion. The increasing proportion of hearings favoring the property rights community and the dominating presence of witnesses representing property, economic, and private interests in committee hearings on property provides sound empirical evidence of their 
access to the policymaking process. Also, finding that they dominated participation in committees which traditionally favor environmental interests suggests that the property rights community is entrenched in the policymaking process. Furthermore, it shows that the jurisdictional control over property hearings by pro-environmental committees did not deny the property rights community access to the decision making process. In agenda setting language, this suggests a mobilization of interests in reaction to the policy consequences of previous environmental laws. In other words, the Schattschneider mobilization proposed by Baumgartner and Jones (1993), and tested in this study, is playing out in this policy area.

Third, my study of the property issue suggests a different function for nonlegislative hearings than what is argued by Talbert, Jones, and Baumgartner (1995). My findings suggest that they are used as a forum to invite rival interests to express their views. Its likely that committee leaders find it less a threat to invite their rivals to nonlegislative hearings rather than give them the opportunity to influence the policymaking process in legislative hearings.

As stated at the outset of this chapter, tracking the property issue in Congress is one of the first steps in explaining why states have adopted property rights legislation. This chapter has established the motive for the property rights community to shift the property rights battle out of the Congressional venue. Stated simply, both the Supreme Court and Congress has failed to resolve the regulatory takings issue adequately. The issue's movement between the Supreme Court and Congress represents a horizontal shift in venues since both venues are federal institutions (Baumgartner and Jones 1993). Although the issue's movement between the two venues represents the potential for a change in policy (King 1991), neither venue produced a sound resolution to the issue. I believe that this lack of success at the federal level motivated the 
property rights community to shift the venue to the states. In turn, the property rights community has realized legislative success at the state level because state legislatures are more sympathetic to grass-roots, local, county, and state level interests. Or, just as Myron Ebell of the property rights organization Frontiers of Freedom states, "state legislators are better able to see the problems and are sympathetic." 29 Perhaps in a more rational light, state level public officials support the concerns of the property rights community in fear of the potential political backlash.

In sum, no federal institution has succeeded in producing a decisive resolution to the regulatory takings issue. The next chapter studies this issue as it moves to yet another venue, the states. It will explain the actions the states have taken to protect private property owners, and more important, why the states have acted on this issue.

29 Taken from a telephone interview with Myron Ebell on May 10, 1999. 


\section{CHAPTER FIVE}

\section{States Move on Property Rights}

In the previous chapters I have discussed how the Supreme Court and Congress have dealt with the property rights issue. The issue has been addressed in each venue and in neither were private property interests able to secure their goals. This Chapter will explore the property rights issue as the venue moves to the states. The issue's movement from the federal venues to the state legislatures represents a vertical shift (Baumgartner and Jones 1993), which is important to understand because one of the goals of this study is to determine whether the vertical shift was induced by the property rights community. Based on Baumgartner and Jones's claim that "losers always have the option of trying to change the policy venue from, say, the national government to subnational units"(1993, p.34), I believe that there was an effort on the part of the property rights community to move the regulatory takings issue out of the federal venues and to the states. The goal of this chapter is to explain why the states have acted to resolve the regulatory takings issue and pass legislation protecting its landowners from government regulations. To get an accurate explanation of the states' actions, I interviewed people closely involved with the property rights issue for information regarding the issue's political circumstances. The next section provides an overview of the interview process.

\section{Interviews}

Throughout this chapter, I will be using information gained from telephone and direct interviews conducted with several actors closely involved with the property rights issue. I 
attempted to follow the same interview protocol with each respondent (see Appendix 2 for further discussion of the interview protocol). Yet, after prompting the respondent with a question, she would often answer openly and extensively on many matters regarding the original question. Therefore, I did not follow the protocol precisely nor did I always have the time to complete the set of questions it contained. The following is a description of the people and organizations that I interviewed.

As discussed in chapter three, the property rights movement is composed of numerous, different public organizations concerned with the protection of private property rights. I interviewed representatives of three of the major interest groups active in the property rights movement. First, I interviewed Ron Arnold of the Center for the Defense of Free Enterprise (CDFE). As vice president of the CDFE, Arnold plays a primary role in drafting and disseminating much of the Wise Use literature which advocates property rights. Also, he is recognized as one of the leaders of the property rights movement and major proponents of takings legislation. Second, I interviewed Myron Ebell of Frontiers of Freedom, a nonprofit, nonpartisan political advocacy organization that works, among other things, to protect property rights and "lead the conservative movement from the front line of the battle against an ever more powerful and intrusive federal government." ${ }^{1}$ Third, I interviewed Michael Wasylik of Defenders of Property Rights, the only national public interest legal foundation devoted exclusively to protecting private property rights. Defenders seeks to ensure the constitutionally guaranteed property rights through a program of litigation, education and legislative support. The group's

\footnotetext{
${ }^{1}$ Taken from the group's mission statement printed on its website at: "Frontiers of Freedom," http://www.ff.org.
} 
founder and president, Nancie Marzulla, is also recognized as one of the nation's leading proponents of property rights and remains very active in the property rights movement through her writings and congressional testimonies. Although I was unable to interview Nancie Marzulla, I will use her opinions gathered through her writings and testimonies to lend insight to the property rights issue.

I also contacted many of the business interests that are active in the property rights movement. I chose who to contact based on who I found participating in congressional hearings on property. That is, the business organizations I contacted where the primary ones showing up at hearings regarding property and property rights throughout the period of my study. I interviewed Cody Lyons of the American Farm Bureau and Judy Brown of the U.S. Chamber of Commerce.

Finally, I attempted to contact several congresspeople and their staff, particulary those that have sponsored takings legislation in either the House or the Senate. I feel their knowledge and experience in dealing with this issue in Congress would be both insightful and valuable. I Interviewed Larry Block, senior counsel to the Senate Judiciary committee. The senate Judiciary committee has considered roughly eight property rights bills over the past thirteen years, and Block's knowledge of the politics of this issue is invaluable.

The chapter begins by describing the venue shift that has occurred over the years regarding property rights. Then the chapter recaps the Supreme Court's and Congress's handling of the property rights issue. The goal of the overview is to illustrate the inability of the property rights community to find satisfaction in each of the venues, which consequently set the stage for state action. Finally, I provide a discussion of the state legislative efforts to resolve the takings issue, including a detailed report of the states that have passed takings legislation and the types of 
legislation enacted.

\section{The Road to the States}

One of the goals of this study is to determine whether the property rights community sought to shift the venue in which the property rights issue was being considered from the federal level to the state level. This query is based on the assumption that a vertical shift of venues actually occurred. That is, that the issue moved between the Supreme Court and Congress before moving to the states. To illustrate the issue's shift of venues, Table 6 provides a timeline of the major policy events regarding property rights as they happened in the Supreme Court, Congress, and the state legislatures. The goal of the timeline is to describe the venue shifting over time, and to note when the shifts occur. The timing of the venue shifts will provide an indication of whether the property rights community has been moving between venues trying to obtain its policy goals.

Table 6: A Property Rights Policy Timeline by Venue

\begin{tabular}{|c|c|c|c|}
\hline Date & Supreme Court & Congress and President & $\begin{array}{l}\text { State Legislatures (type } \\
\text { of taking legislation)* }\end{array}$ \\
\hline 1887 & $\begin{array}{l}\text { Mugler v Kansas - Supreme Court declines to } \\
\text { find takings for regulations that serve } \\
\text { significant public purposes }\end{array}$ & & \\
\hline 1915 & $\begin{array}{l}\text { Hadacheck } v \text { Sebastian - Supreme Court } \\
\text { declines to find takings for regulations that } \\
\text { serve significant public purposes }\end{array}$ & & \\
\hline 1922 & $\begin{array}{l}\text { Pennsylvania Coal v Mahon -Supreme Court } \\
\text { defines a taking when a government regulation } \\
\text { goes "too far" }\end{array}$ & & \\
\hline 1963 & & $\begin{array}{l}\text { House subcommittee on Real Property } \\
\text { Acquisition holds hearing entitled "Real } \\
\text { Property Acquisition Practices and Adequacy } \\
\text { of Compensation in Federal and Federally } \\
\text { Assisted Programs" }\end{array}$ & \\
\hline
\end{tabular}


Table 6: A Property Rights Policy Timeline by Venue

\begin{tabular}{l}
\hline Date \\
\hline 1964 \\
1965 \\
$1978 \quad \begin{array}{l}\text { Pennsylvania Coal Transportation Company v } \\
\text { New York - Supreme Court includes } \\
\text { "investment-backed expectations" of the } \\
\text { property owner as part of criteria for evaluating } \\
\text { takings challenges }\end{array}$
\end{tabular}

Keystone Bituminous Coal Association v DeBenedictus - Supreme Court offers "bundle of rights" concept in determining a taking

First Evangelical Lutheran Church of Glendale v County of Los Angeles - Supreme

Court guarantees compensation remedy to takings violations

Nollan v California Coastal Commission Supreme Court offers "essential nexus" concept in determining a taking

1988 Agins v City of Tiburon - Supreme Court develops two-part legal test, the "Agins Test," to determine a taking

House subcommittee on Real Property Acquisition holds hearing entitled "Real Property Acquisition Practices and Adequacy of Compensation in Federal and Federally Assisted Programs"

Senate subcommittee on Intergovernmental Operations holds hearing on S.1201,

"Uniform Compensation for Relocation"

House subcommittee on Forests holds hearing on H.R.954, "Summer Home in the Stanislaus Forest, Relief of Harriet C. Chambers, and Acceptance of Cash in Land Exchange Transfers"

Senate subcommittee holds hearings on S.1108, "Uniform Relocation Assistance Act Amendments of 1979"

Senate passes S.2363, "Uniform Relocation Assistance Act Amendments of 1981"

Senate passes S.531, "Uniform Relocation Act Amendments of 1983"

Senate passes S.249," Uniform Relocation Act Amendments of 1985"

H.R.5363, "Bill to Amend the Interest Provisions of the Declaration of Taking Act" becomes public law
President Reagan issues Executive Order 12630 
Table 6: A Property Rights Policy Timeline by Venue

\begin{tabular}{|c|c|c|c|}
\hline Date & Supreme Court & Congress and President & $\begin{array}{c}\text { State Legislatures (type } \\
\text { of taking legislation)* }\end{array}$ \\
\hline 1989 & & $\begin{array}{l}\text { House subcommittee on Law and } \\
\text { Governmental Relations holds hearings on } \\
\text { H.R.3408, "White Sands Fair Compensation } \\
\text { Act of 1989" }\end{array}$ & \\
\hline 1991 & & $\begin{array}{l}\text { Senate subcommittee on Government } \\
\text { Information, Justice, and Agriculture holds } \\
\text { hearings on Section } 404 \text { - Clean Water Act } \\
\text { Senate subcommittee on Public Lands, } \\
\text { National Parks holds hearings on S.867, } \\
\text { "White Sands Fair Compensation Act of } \\
\text { 1991" }\end{array}$ & $\begin{array}{l}\text { Legislation enacted: } \\
\text { Washington (TA) }\end{array}$ \\
\hline 1992 & $\begin{array}{l}\text { Lucas v South Carolina Coastal Council - } \\
\text { Supreme Court offers "all economically viable } \\
\text { use" criteria in determining a taking }\end{array}$ & & $\begin{array}{l}\text { Legislation enacted: } \\
\text { Arizona (TA), Delaware (TA) }\end{array}$ \\
\hline 1993 & & & $\begin{array}{l}\text { Legislation enacted: } \\
\text { Indiana (TA), Utah (TA) }\end{array}$ \\
\hline 1994 & $\begin{array}{l}\text { Dolan } v \text { City of Tigard - Supreme Court } \\
\text { applies Agins Test to determine a takings }\end{array}$ & & $\begin{array}{l}\text { Legislation enacted: } \\
\text { Idaho (TA), Mississippi (TC), } \\
\text { Missouri (TA), Tennessee } \\
\text { (TA), Utah (TA), West } \\
\text { Virginia (TA) }\end{array}$ \\
\hline 1995 & & $\begin{array}{l}\text { House passes H.R.9, "Job Creation and Wage } \\
\text { Enhancement Act of 1995" } \\
\text { House Passes H.R.925, "Private Property } \\
\text { Protection Act of 1995" } \\
\text { House Resources committee holds hearings } \\
\text { on H.R.2275, "Endangered Species Act } \\
\text { Amendments" } \\
\text { Senate Judiciary committee reports S.605 to } \\
\text { Senate }\end{array}$ & $\begin{array}{l}\text { Legislation enacted: } \\
\text { Arizona (TA), Florida (TC), } \\
\text { Idaho (TA), Kansas (TA), } \\
\text { Louisiana (TA\&C), } \\
\text { Mississippi (TC), Montana } \\
\text { (TA), North Dakota (TA), } \\
\text { Texas (TA\&C), Virginia } \\
\text { (TA), Wyoming (TA) }\end{array}$ \\
\hline 1996 & & $\begin{array}{l}\text { House fails to pass H.R.3752, "American } \\
\text { Land Sovereignty Protection Act of 1996" }\end{array}$ & $\begin{array}{l}\text { Legislation enacted: } \\
\text { Maine (TA), Michigan (TA) }\end{array}$ \\
\hline 1997 & & $\begin{array}{l}\text { House passes H.R.1534, "Priavte Property } \\
\text { Rights Implementation Act of 1997" } \\
\text { Senate Judiciary committee holds hearings on } \\
\text { S.781, "Omnibus Property Rights Act of } \\
\text { 1997" } \\
\text { Senate Judiciary committee holds hearings on } \\
\text { S.1204, "Property Owners Access to Justice } \\
\text { Act of 1997" }\end{array}$ & \\
\hline 1998 & & & $\begin{array}{l}\text { Legislation enacted: } \\
\text { Idaho (TC) }\end{array}$ \\
\hline
\end{tabular}

* TA $=$ Takings Assessment, $\mathrm{TC}=$ Takings Compensation, $\mathrm{TA \& C}=$ Takings Assessment and Compensation 
Table 6 reports the times in which the different venues considered and acted on the property rights issue. The Supreme Court and Congress were the primary venues considering the issue prior to 1991 (see chapter three and chapter four for a detailed discussion of the property rights issue in the Supreme Court and Congress respectively). In brief, the Supreme Court offered its first favorable ruling for the property rights community in 1922. Also, Congress held hearings during the 1960s concerning the property rights of individuals whom were burdened by governmental actions under federal and federally assisted programs. During the 1970s and 1980s, the Supreme Court considered five major cases concerning regulatory takings and Congress held hearings and enacted laws concerning property rights as they pertained to the eminent domain practices and procedures of the federal government. In 1986, the first takings bill becomes public law, and soon afterwards President Reagan issued Executive Order 12630. Table 6 shows that up to the early 1990s the property rights issue has shifted between the Supreme Court, which has provided no definite resolution, and Congress, where the property rights community has maintained a presence in the policymaking process over the past thirty-five years, yet have failed to obtain legislative success. Thus, given its failure at the federal level, the property rights community has incentive to move this issue to the states where they hope to find satisfaction.

The property rights issue shifts to the states in the early 1990s. Table 6 shows that in every year since 1991 (except for 1997) states have enacted some form of property rights legislation. The states' actions represent the vertical shift of venue that I have been alleging throughout this study. It should be noted that Congress and the Supreme Court continued to address the issue throughout the 1990s. Yet, the states have proven to be the only venue to provide a substantial and definite resolution to the regulatory takings issue (forthcoming sections 
will describe the states actions in detail).

The next sections provide a brief overview of the attempts by the Supreme Court and Congress to protect property rights. The overviews will emphasize the property rights community's inability to secure its policy goals in these venues and suggest some reasons why they have failed based upon the testimonies and opinions of actors closely involved with the issue.

\section{The Court's Deferment}

Chapter three described the Supreme Court's inability to provide clear guidance as to what governmental actions constitute a taking, and the circumstances under which a taking is compensable. Except when the government exercises its power of eminent domain and physically invades one's property, and in the very narrow case when a government regulation deprives an owner of all "economically viable" use of the land, the U.S. Supreme Court has failed to define when a governmental regulation constitutes a taking. Instead of offering clear guidance, the Court has based its rulings on vague decrees, such as the infamous "too far" edict, the "bundle of property rights" theory, and the "essential nexus" condition, and offered only indefinite formulas to determine when compensable takings occur. Therefore, despite the judicial efforts to resolve the regulatory takings issue, takings jurisprudence is still unclear.

The legal history of this issue raises the question whether the courts are the appropriate venue to resolve the regulatory takings issue. Nancie Marzulla, of Defenders of Property Rights, suggests that maybe they are not. In her testimony before the U.S. House of Representatives Committee on Resources, she asserts that under our constitutional system it is the function of the 
legislative, not judicial, branch to balance competing social and economic concerns so as to arrive at a definition of a taking which need not be recreated in an ad-hoc basis each time the court is presented with the issue. ${ }^{2}$ Chief Judge Loren Smith of the Court of Federal Claims supports this argument in stating that,

"There must be a better way to balance legitimate public goals with fundamental individual rights. Courts, however, cannot produce comprehensive solutions. They can only interpret the rather precise language of the Fifth Amendment to our constitution in very specific factual circumstances. To the extent that the protections of the Fifth Amendment are a bulwark of liberty, they should also be understood to be a social mechanism of last, not first, resort. Judicial decisions are far less sensitive to societal problems than the law and policy made by the political branches of our great constitutional system. At best, courts sketch the outlines of individual rights, they cannot hope to fill the portrait of wise and just societal and economic policy." ${ }^{3}$

It seems that judicial branch has deferred to the legislative branch to resolve the takings issue, and both determine when a regulatory takings occurs and pass legislation that will provide a fair and prompt remedy when a federal regulation results in a taking of private property without just compensation. With respect to my study, this marks a shift of venues for this issue. In other words, the courts have proven to be an inadequate venue to resolve this issue. Thus, Congress became the arena in which the property rights community sought a resolution to this issue.

\section{Congressional Inaction}

Chapter four provides a thorough analysis of the property issue in Congress. The research shows that Congress has failed to pass any substantial laws to resolve the property rights issue

\footnotetext{
2 Taken from the testimony of Nancie G. Marzulla before the U.S. House of Representatives Committee on Resources, April 14, 1999. This testimony may be viewed at the Defenders of Property Right website at, http://www.defendersproprights.org/testimony.html.

3 Ibid.
} 
(see Appendix 1). This, despite the evidenced access to the policymaking process in Congress, has left the property rights community seeking other institutional arenas in which to pursue legal protection from government regulations that "take" property without providing just compensation.

Congress's unwillingness to enact takings legislation indicates the obvious problem that the bills do not have the votes to pass. To find why the property rights bills do not have the votes, I asked my interviewees their opinions on the matter. In response, there were primarily three reasons for Congress's failure to enact takings legislation: political divisions, disorganization, and resource disparity.

\section{Political Division}

The first reason for Congress's inaction involves the political differences that government officials bring to their job. For instance, Larry Block, senior counsel for the Senate Judiciary committee, commented that the property rights issue in the Senate demonstrates that chamber's cultural division between the Democrats and the Republicans. He claims that "the Democrats favor regulation, and the Republicans want laissez faire capitalism," and, since the Democrats view the property rights bills as an attack on government's ability to regulate and as an attack on the environment, they do not support them. ${ }^{4}$

Myron Ebell, of Frontiers of Freedom, speaks of a similar division that prevents a consensus view on the issue and threatens the success of property rights bills. He points out the split between urban and rural America that is being played out in Congress. Ebell expresses that "urban representatives think they know what is best for the environment, and rural Americans,

\footnotetext{
${ }^{4}$ Taken from a telephone interview with Larry Block on May 6, 1999.
} 
who own and work the land, feel they know what is best, not government." ${ }^{5}$ He argues that this division is at the heart of the political battle over property rights. That is, this division prevents the passing of takings bills because "lots of people are getting something for free - that is, the use of land - so they have a vested interest to stop property rights bills." No doubt, this frustrates the property rights community as the environmentalists fight to kill property rights legislation and continue to enjoy the public benefits provided by the environment without paying compensation to the owners of the property.

\section{Disorganization}

The second reason for Congress's inaction involves the character of the property rights movement. The people I interviewed agree that the movement has not matured enough to significantly influence policy at the federal level. Maturity in this context refers to its age and organization. For instance, Michael Wasylik, of Defenders of Property Rights, admits that the movement is "too young, disorganized, and small." And, although there are over 1200 property rights groups and land use groups in America (Ebell 1999), a lot of them are fighting local, specific issues which results in a fragmented movement.

The movement's immaturity and disorganization has two important implications for its success in influencing policy. First, the movement's disorganization has prevented it from communicating its stance on property rights sufficiently. Therefore, "the federal legislators do not see the broad support out there that they prefer, and that makes them comfortable in passing takings legislation" (Wasylik 1999). Second, the movement's fragmentation makes it difficult to organize nationally because "people normally do not get involved until their property is effected"

\footnotetext{
${ }^{5}$ Taken from a telephone interview with Myron Ebell on May 10, 1999.
} 
(Ebell 1999). Thus, without a strong national presence it is difficult to influence the outcomes of public policy at the federal level.

A possible explanation why federal government officials do not see the broad public support for property rights laws and why people are reluctant to get involved is the media's role in conveying the property rights issue. No doubt, the media in the United States can play a large role in facilitating the public concern given an issue. However, Ebell argues that "it is hard to get media sympathy for property owners, while it is easy to get sympathy for poor people when their rights are violated." Ebell is suggesting that since property owners tend to be wealthier than others, the media does not consider their rights, or violation thereof, as offensive and therefore is less likely to publicize such cases. Therefore, the property rights violations that serve to fuel the property rights movement's antagonism, and which have been documented throughout this study (see chapter three), do not receive a great deal of media attention.

To test Ebell's claim that the property rights issue is not a hot media topic, I studied the evening news broadcasts and special reports of the three major networks, ABC, CBS, and NBC using Vanderbilt University's TV News Archive. ${ }^{6}$ I found that from 1968 to present there were no stories broadcasted concerning property rights or regulatory takings. This evidence supports Ebell's claim that the media does not interpellate the property rights issue greatly. As a result, less people are aware of the issue and less people understand the implications of property rights violations, thus, abating the public pressure to resolve the issue.

\footnotetext{
${ }^{6}$ Vanderbilt's TV News Archive holds more than 30,000 individual network evening news broadcasts and may be accessed and searched at, http://tvnews.vanderbilt.edu.
} 


\section{Resource Disparity}

The third reason for Congress's inaction is the resource disparity between the property rights community and the environmentalists. Resources in this context refers to both managerial and fiscal resources. That is, the property rights community does not have the organization nor the financial support necessary to compete with the environmentalists when it comes to battling over federal takings legislation (Switzer 1997). The members of the property rights community that I interviewed considered their movement to be "outgunned" at the federal level. In other words, because of its relative immaturity compared to the environmental movement (see chapter three for evidence of the environmental movement's revenues and membership), the property rights movement "lacks the resources it takes to pressure Congress to enact taking legislation" (Ebell 1999). It should be noted, however, that based on the findings presented in chapter four, the resource disparity did not prevent the property rights community from participating in Congressional property hearings. In brief, my studies have shown that the property rights community has maintained a presence in property hearings, and since 1987 have dominated involvement in such hearings. Therefore, this suggests that access does not guarantee influence when dealing with public policy.

From all indications, the failure of Congress to pass takings legislation stems from the political divisions among its members and the disorganization of the property rights community. These obstacles stand in the way of any federal legislative solution to the property rights issue in America. Moreover, they serve as the incentives for the property rights community to move this issue out of Congress and into the state legislatures. The next section discusses the states' actions toward the issue. 


\section{State Takings Legislation}

Since 1991, twenty states have adopted some type of takings legislation, and every state but Connecticut has considered takings legislation. Table 7 reports the type of takings legislation enacted by each state. ${ }^{7}$

Table 7: State Takings Legislation by Type

\begin{tabular}{ccc}
\hline Compensation & Assessment \\
\hline Florida ("inordinate burden") & Arizona & North Dakota \\
Idaho* ("unreasonable burden") & Delaware & Tennessee \\
Louisiana* (20\% diminution) & Indiana & Utah \\
Mississippi (40\% diminution) & Kansas & Virginia \\
Texas* (25\% diminution) & Maine & Washington \\
& Michigan & West Virginia \\
* & Missouri & Wyoming \\
\hline Indicates the state has & Montana \\
\hline
\end{tabular}

* Indicates the state has enacted both types of legislation.

Washington enacted the first state takings legislation in 1991, only to have it rejected by a 3-2 margin in a public vote on a 1995 ballot referendum (Carson 1996). Arizona and Delaware enacted takings legislation in 1992, although Arizona's bill was later rejected by a 60/40 margin in a public vote on a 1994 ballot referendum. In 1993, Indiana and Utah enacted takings legislation, and thirty states considered approximately sixty-five takings bills. In 1994, Idaho, Mississippi, Missouri, Tennessee, Utah, and West Virginia enacted takings legislation, and

\footnotetext{
${ }^{7}$ Data concerning the adoption dates of state takings legislation is taken from internet website entitled, "Takings Legislation in the 50 United States," at: http://www.igc.apc.org/arin/states.html.
} 
thirty-one states considered approximately seventy takings bills. In 1995, Arizona, Florida, Idaho, Kansas, Louisiana, Mississippi, Montana, North Dakota, Texas, Virginia, and Wyoming enacted takings legislation, and forty states considered approximately ninety takings bills. In 1996, Maine and Michigan enacted takings legislation, and twenty-nine states considered more than sixty takings bills. And, in 1998, Idaho enacted takings legislation.

Overall, states have chosen between the assessment and the compensation type of takings legislation in their efforts to protect property owners, with the exception of Idaho, Louisiana, and Texas which have enacted a combination of both. There is considerable variation within each of the two general types of property rights laws. In a recent article, Mark Cordes (1997) compiled the variations within assessment statutes into three categories. The first category considers the assessment process used and the degree of administrative burden imposed on state agencies. In Indiana and Delaware the attorney general decides if agency rules are in compliance, while in Idaho, Michigan, and Tennessee, the agencies make their own informal determinations pursuant to attorney general guidelines. ${ }^{8}$ Also, Kansas, Louisiana, Montana, North Dakota, Texas, Utah, and West Virginia require the state agency to prepare a formal written analysis that must include assessments of alternative actions that might have less impact on property rights. ${ }^{9}$ In addition, Louisiana, Montana, North Dakota, and West Virginia require an estimate of the cost of

\footnotetext{
${ }^{8}$ Delaware Code Ann. tit. 29, p.605 (Supp. 1996); Indiana Code Ann. Section 4-22-2-32 (West Supp. 1996); Idaho Code, Section 67-8001 (1995); Michigan Legis. Serv. 101 (West); Tennessee Code Ann., p.12-1-201 to 203 (Supp. 1996).

${ }^{9}$ Kansas Stat. Ann., p.77-701 (supp. 1995); Louisiana Rev. Stat. Ann., section 3:3609 (West Supp. 1997); Montana Code Ann., p.2-10-105 (1995); North Dakota Cent. Code, section 28-32-02.5 (Supp. 1995); Texas Gov't Code Ann., section 2007.043 (West 1996); Utah Code Ann., section 93-90-4 (Supp. 1996); West Virginia Code, section 22-1A-3 (1994).
} 
compensation and the source of payment. ${ }^{10}$ Finally, Kansas, Utah, West Virginia, Louisiana, and North Dakota require that the assessment contain an affirmative justification for the restriction. ${ }^{11}$

The second category of assessment statutes considers their scope, meaning the range of government bodies subject to the assessment requirement and the types of actions that must be assessed. West Virginia and Michigan limit the assessment process to select state agencies. ${ }^{12}$ Whereas, Delaware, Kansas, Montana, North Dakota, Tennessee, and Utah impose their requirements on all state agencies, but not their political subdivisions. ${ }^{13}$ Finally, Idaho, Texas, and Louisiana, include both state agencies and all or most local governments. ${ }^{14}$

The final category of assessment statutes considers whether the legislation creates any additional duties subject to judicial review. Idaho, Kansas, and Washington discourage judicial review of the assessments. ${ }^{15}$ Delaware and Texas require limited judicial review (Delaware to ensure that the attorney general has reviewed the rule in question and Texas for voiding the action, but only if no assessment has been prepared). ${ }^{16}$ Other states have no definite rule.

${ }^{10}$ Louisiana Rev. Stat. Ann., section 3:3609(B)(8), (9) (West Supp. 1997); Montana Code Ann., section 210-105(2)(C) (1995); North Dakota Cent. Code, section 28-32-02.5 (Supp. 1995); West Virginia Code, section 221A-3(a)(6) (1994).

${ }^{11}$ Kansas Stat. Ann., section 77-706(1) Supp. 1995); Utah Code Ann., section 63-90-4 (Supp. 19960); West Virginia Code, section 22-1A-3(a)(1) (1994); Louisiana Rev. Stat. Ann., section 3:3699(B)(1) (West Supp. 1997); North Dakota Cent. Code, section 28-32-02.5(1)(b) (Supp. 1995).

${ }^{12}$ West Virginia Code, section 22-1A-2 (1994); H.B. 4433, $88^{\text {th }}$ Leg., Regular Sess. (Mich. 1995) (enacted).

${ }^{13}$ Delaware Code Ann. tit. 29, p.605 (Supp. 1996); Kansas Stat. Ann., section 77-706(1) (Supp. 1995); Montana Code Ann., section 2-10-103(3) (1995); North Dakota Cent. Code, section 28-32-02.5(1) (Supp. 1995); Tennessee Code Ann., section 12-1-201 (Supp. 1996); Utah Code Ann., section 63-90-2-(4) (Supp. 1996).

${ }^{14}$ Idaho Code, section 67-8003 (1995); Texas Gov’t Code Ann., section 2007.042(a) (West 1996); Louisiana Stat. Ann., section 3:3602(13) (West Supp. 1997).

${ }^{15}$ Idaho Code, section 67-8003 (1995); Kansas Stat. Ann., section 77-706(2) (supp. 1995); Washington Rev. Code, section 36.70A.370(4) (West Supp. 1997).

${ }^{16}$ Delaware Code Ann. tit. 29, section 605(b) (Supp. 1996); Texas Govt Code, section 2007.044(a) (West 1996). 
Compensation statutes are the other type of property rights laws that states have considered. Unlike assessment statutes, compensation legislation provides monetary relief to adversely affected landowners once the diminution in value reaches a certain point. The greatest variation within compensation statutes pertains to the threshold at which a percentage diminution in value triggers the requirement for compensation. The Mississippi statute requires that compensation be paid for regulation of agriculture and forest land causing a 40 percent or greater loss in value. ${ }^{17}$ Louisiana's similar law is triggered by a 20 percent diminution in value. ${ }^{18}$ The Texas statute pertains to any property, and requires government compensation when governmental action reduces the property value by 25 percent or more. ${ }^{19}$ One commonality among compensation laws is that they almost always preclude compensation where the proscribed use constituted a common law nuisance.

The anomalies among the state compensation statutes are Florida's "Bert J. Harris, Jr., Private Property Rights Protection Act" and Idaho’s "Protection of Real Property Rights" bill. Unlike other states, Florida's and Idaho's statutes do not set a percentage diminution. Instead, they require compensation when a government action inordinately burdens (Florida) or unreasonably burdens (Idaho) real property use. ${ }^{20}$ The states define the two different concepts similarly. The statutes define "inordinately burdened" and "unreasonably burdened" as meaning either that the land owner is "permanently unable to attain the reasonable investment-backed expectations" for the property, or that an owner "bears permanently a disproportionate share of a

${ }^{17}$ Mississippi Code Ann., Section 49-33-1 to 49-33-19 (Supp. 1996).

${ }^{18}$ Louisiana Rev. Stat. Ann., Section 3:3601-02 (West Supp. 1997).

${ }^{19}$ Texas Government Code, Section 2007.002.

${ }^{20}$ Florida Stat. Ann., Sections 70.001(2), (3)(e) (West Supp. 1997); Idaho Code, Section 67: Chapter 84 (1998). 
burden imposed for the good of the public, which in fairness should be born by the public at large." ${ }^{21}$ The "inordinately burdened" and "unreasonably burdened" standard for compensation is more responsive to the facts of any given situation, making the standard more flexible than the traditional percentage diminution rule. Also, by applying the "inordinate burden" standard with "investment-backed expectations" and "disproportionate burdens," the bill reflects some of the basic Supreme Court principles on takings, particularly that which is expounded in the Penn Central case (Cordes 1997).

Figure 9: Property Rights Legislation by State, 1998

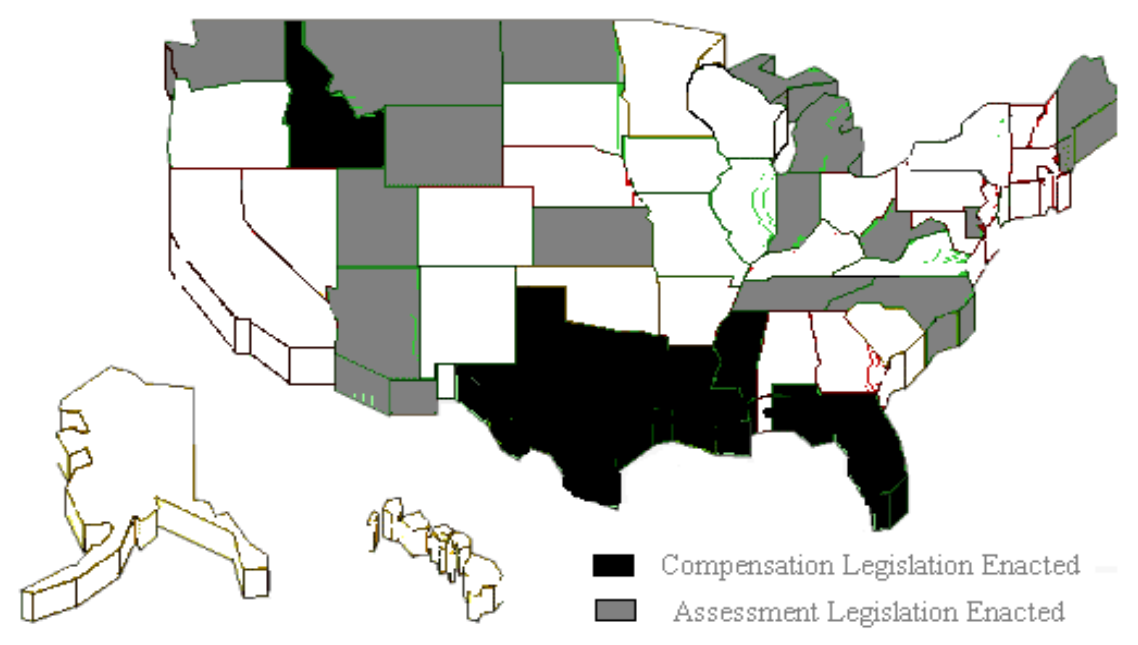

${ }^{21}$ Florida Stat. Ann., Section 70.001(3)(e) (West Supp. 1997); Idaho Code, Section 67: Chapter 84(1) (1998). 
In summary, twenty states have enacted either assessment legislation or compensation legislation, or a combination of both, to protect private property interests from what is often viewed as growing government regulation (See Figure 9). By forcing government to consider the implications of their actions, assessment statutes strive to ensure that government policies do not inadvertently effect takings of private property. Compensation statutes provide relief to the land owner by establishing the guidelines for compensation whenever it is proved that the government regulation caused a diminution in property value. Together, these measures represent the legislative successes of the property rights movement, and clearly show that the states have taken decisive steps to resolve the regulatory takings issue. Yet, why has the property rights community been successful in obtaining its policy goals in the states, whereas it has failed in the Supreme Court and Congress? To answer this question, I interviewed several actors closely involved in the issue to explain the state level success. The following section reports what I have discerned from the interviews.

\section{A Closer Look at State Action}

Throughout the study I have claimed that the property rights community has strategically sought to shift the political battle over property rights out of the federal venues and into the states where the political environment is more receptive to their interests. Since its access to the policymaking process in Congress has not yielded legislative success, it is logical that the property rights community would want to move the fight over property rights to a different venue. This assertion fits with the contemporary knowledge of venue shifting (Baumgartner and

Jones 1993; King 1991, 1992; Worsham 1997, 1998) that argues that those on the losing side of a 
debate will have the incentive to search for a more favorable venue for consideration of an issue. I will use information gained from telephone and personal interviews, as well as previous research on interest group behavior regarding this particular issue to try to explain this shift of venues, or more specifically, why the states have taken decisive moves to protect private property rights.

\section{Strategy or Inevitability?}

One of the goals of this study is to determine if the vertical shift of venues experienced by the property rights issue was a strategic move on the part of the property rights community. From the property rights community's perspective, the idea is to shift the venue in which this issue is being considered from Congress, where they have had no legislative success, to the state legislatures, where they may stand a better chance at influencing policy. The unanimous reply I received in response to this query was that there was no national nor concerted effort to move the issue from the federal level to the states. That is, the vertical shift that occurred was not the result of strategic behavior by the property rights community. For instance, Judy Brown, legislative assistant to the U.S. Chamber of Commerce, maintains that "the Chamber had no national directive to shift the issue (takings) to the states." 22 In fact, Ron Arnold, of the Center for the Defense of Free Enterprise, implies the opposite in his statement that, "there is not a strategy to devolve the issue, nor to take focus off Congress...but to keep pressure on the federal government to the point that all types of government are covered by federal property rights legislation" (Arnold 1999). This assertion seems accurate given the evidence found in chapter four that in

\footnotetext{
${ }^{22}$ Taken from a telephone interview with Judy Brown on May 5, 1999.
} 
recent years the property rights community has experienced an increasing degree of participation in the policymaking surrounding property in Congress. Also, it is unlikely that the property rights community could formulate and implement such a scheme given its disorganization and lack of resources at the national level. Furthermore, given the many hundreds of local property rights groups and the diversity of their interests, it would be incredibly difficult for a resolution to be generated from the national level that addressed the specific concerns. Therefore, the vertical shift of venues was not influenced by any preconceived attempts on the part of the property rights community to move the issue from the federal level to the states. This conclusion forces me to reject my earlier proposition that the property rights community sought to manipulated the vertical shift of venues to increase their advantage in the agenda battle. The question remains that if the states are not reacting to a national directive on the part of the property rights community to address the regulatory takings issue, why are they taking such decisive actions?

One common explanation to why the states have acted on the property rights issue was inferred from the interviews. Cody Lyons of the American Farm Bureau sums up the explanation best with his assertion that, "states have acted because the state legislators are in tune with what is needed locally." 23 This explanation suggests that the proximity of state legislators to the property rights concerns within their respective states is the key reason for their action. Larry Block, senior counsel to the Senate Judiciary committee, adds that since by its very nature the property rights issue is a "local issue, not a federal issue," affecting property owners that live in the localities of a state, "it is inevitable that the states are going to rush to solve the issue." ${ }^{24}$ The

\footnotetext{
23 Taken from a telephone interview with Cody Lyons on May 5, 1999.

${ }^{24}$ Taken from a telephone interview with Larry Block on May 6, 1999.
} 
inevitability of state action is questionable, since only twenty states have enacted takings legislation to date. However, there is little doubt that state level government officials, more than their peers on the federal level, "see the problem and are sympathetic" to the concerns of property owners (Ebell 1999). Randy Moffett (1996) suggests additional evidence of this legislative "sympathy" in his recent study that found that ag/industry and business groups (both considered part of the property rights community) in Georgia, Indiana, and West Virginia regarded their state legislatures to be supportive of their position on the regulatory takings issue.

\section{A Case for Sympathy or Group Pressure?}

Myron Ebell, of Frontiers of Freedom, suggests that state legislators are more sympathetic to property rights concerns because they are not "captive" by national environmental interest groups (see chapter three for data regarding the strength of national environmental groups). He argues that congressmen and -women are "afraid" of the environmental groups' political influence, and thus tend not to favor federal property rights legislation that stymies environmental objectives. This helps explain why, despite its access to the policymaking surrounding property matters in Congress, the property rights community has been unable to realize its legislative goals.

It seems that the environmental groups may not have the same political influence in the states as they do at the federal level. Instead, there is evidence that the property rights community has a greater political influence than environmental groups at the state level. In a recent study designed to determine the possible reasons for state level success or failure in passing takings legislation, Randy Moffett (1996) surveyed forty-five organizations - including agricultural and 
extractive industry associations, business associations, unions, grassroots citizens' property rights groups, state environmental organizations, and national citizen action and environmental groups in Georgia, Indiana, New York, and West Virginia to examine state level lobbying strategies in the area of regulatory takings. The results of Moffett's study suggest three explanations for why the property rights community is having legislative success at the state level: political strength and public influence, legislative influence, and lobbying. Below I will discuss each explanation, and pay special attention to West Virginia as a case study.

\section{Political Strength and Public Influence}

Moffett (1996) found that economic-based organizations (ag/industry and business groups) perceived themselves as being politically stronger than their opponents, as well as having more influence in the general public. Political strength in this context refers to financial and organizational capacity. Important also, state environmental groups perceived themselves as only as strong as or weaker than their opponents in both regards. Previous research shows that issues that are backed by groups with significant political clout are more likely to reach and ascend the governmental agenda (Cobb and Ross 1997). Therefore, the political influence of the property rights community in the states seemingly affects the consideration of takings legislation. In West Virginia, ag/industry groups considered themselves much stronger than their opponents, while environmental groups claimed to be politically weaker. Also, the ag/industry groups surveyed in West Virginia expressed that their influence among the general public had increased in the past five years, while a much smaller fraction of environmental groups surveyed believed that their influence had increased. In addition, environmental groups viewed their opponents as having substantial political clout, and believe that the state legislature was much more receptive to the 
concerns of business and industry than to the environmental community. These findings suggest that the political strength and the public influence of the property rights community in West Virginia facilitated the agenda status and consideration of the takings issue. No doubt these factors played a significant role in West Virginia's passing of takings legislation in 1994.

\section{Legislative Influence}

Moffett's study (1996) reports that the proponents of property rights, including ag/industry and business groups, considered their influence among state legislators to have increased after the 1994 state elections. The data in Table 1 supports this claim in showing that fifteen states have enacted takings legislation since 1994. By comparison, their opponents, including state and national environmental groups, considered their legislative influence to have either remained consistent or decrease after the elections. In this light, the 1994 elections may be viewed as a change in the "political climate" (a.k.a. Kingdon 1995) that boded well for the property rights community. And, based on Schattschneider's (1960) claim that a goal of any coalition is to manipulate the assignment of program responsibilities so that the government units it "controls" have the most authority, it may be argued that the increased legislative influence enabled the property rights community to affect policy change. In West Virginia, the 1994 election netted a gain for the Republican party of six seats in the Senate and ten seats in the House of Delegates. As a result, ag/industry groups considered their influence to have increased, and reported that they intended to increase their legislative efforts given the increase in the number of legislators sympathetic to their concerns. On the other hand, state environmental groups and the state affiliates of national environmental groups felt that their influence in the 
state legislature had decreased since the elections. In policy change language, the property rights community took advantage of the changing political climate in the state to enhance their legislative influence and advocate the enactment of takings legislation. Its influence and efforts seemingly paid off as West Virginia passed takings legislation in 1994.

\section{Lobbying}

Moffett (1996) found that farm, industry, and business and trade organizations are more inclined to maintain a full-time lobbyist(s) on their staff. On the other hand, very few environmental groups or citizen groups relied on a full-time paid lobbyist to appear at the state legislatures, instead relying on their members to volunteer their services. Previous research by DiGregorio (1992) and Leyden (1995) has shown that groups maintaining a full-time lobbying presence at the national level are more likely to be asked to provide testimony at committee hearings. These findings suggest that groups with superior organizational resources are more likely to participate in the policymaking and express their concerns to decision makers at the state level as well. Therefore, the ability for certain groups to employ a professional lobbyist and maintain a constant presence in the legislative community provides the advantage of establishing closer working relationships with individual legislators, which in turn provides the opportunity to influence policy. In West Virginia, all the industry and labor organizations surveyed reported to have employed professional lobbyists during the legislative session, including the organization's president and chief executive officer. Conversely, their opponents all relied on volunteer lobbyists to represent their interests. The property rights community's ability to maintain a constant presence in the West Virginia legislature and maintain direct contact between legislators and its lobbyists was an effective means of lobbying for policy change, as is suggested by an 
industry lobbyist who states, "when our person sits down with elected officials, that probably does more than anything else" (Moffett 1996).

In summary, state legislators are more sympathetic to the concerns of private property owners than their peers on the national level. Also, it seems that the property rights community's political strength, legislative influence, and lobbying efforts impact the state's decision to enact takings legislation. Together, the legislative sympathy and group pressure within a state affects the state's consideration of the regulatory takings issue, and its decision whether or not to enact laws to resolve the issue.

\section{Conclusion}

The property rights issue has experienced a vertical shift of venues. Unable to realize its policy goals in the Supreme Court and Congress, the property rights community has found satisfaction in the states where some have passed takings legislation. From all indications, state action is not the result of a grand strategy on the part of the property rights community. Instead, state legislatures are reacting to the local problems they see and the political pressure placed on them by the groups within the state. To put it succinctly, "state level action is because the abuses are at the state level, the activists are at the state level, and the property rights movement is largely a reaction to state regulation." 25

\footnotetext{
${ }^{25}$ Taken from a personal interview with Michael Wasylik on June 19, 1998.
} 
The battle over property rights continues to be fought in the courts, Congress, and the state legislatures. The dynamic and emotional nature of this issue ensures the continuance of this debate for may years to come as the opposing sides confront one another with very different perspectives on the matter. Although a federal resolution to the issue is not likely in the near future, the property rights community will undoubtedly continue their battle for agenda control in Congress while trying to add to their legislative successes in the states. The consequences of this battle are significant for the American public. In fact, given the legal, economic, and environmental implications that any resolution will place on the American public, this issue is arguably one of the most important of our time. 


\section{$\underline{\text { References }}$}

Aberbach, Joel D. 1990. Keeping a Watchful Eye: The Politics of Congressional Oversight. Washington D.C.: Brookings.

Alliance for America. 1998. Web site at http://www.allianceforamerica.org.

Alliance for Environment and Resources. 1998. Web site at http://www.cat.org.au/a4a/fake4.html

Alston, Dana. February 1, 1994. Interview with Mark Dowie, 1995.

Arnold, Ron. April 30, Telephone Interview.

Arrensen, David A. 1988. "Compensation for Regulatory Takings: Finality of Local Decisionmaking and the Measure of Compensation." Indiana Law Journal. 63:649-68.

Austin, Regina and Michael Schill. 1994. "Black, Brown, Red, and Poisoned," in Unequal Protection, ed. Robert Bullard. San Francisco: Sierra Club.

Bachrach, Peter, and Morton S. Baratz. 1962. "Two Faces of Power”. AmericanPolitical Science Review. 56:947-952.

Bast, Joseph, L., Peter J. Hill, and Richard C. Rue. 1994. Eco-Sanity. Lanham, M.D.: Madison Books.

Baumgartner, Frank R. and Bryan D. Jones. 1991. "Agenda Dynamics and Policy Subsystems.” Journal of Politics 53:1044-74.

Baumgartner, Frank R. and Bryan D. Jones. 1993. Agendas and Instability in American Politics. Chicago: University of Chicago Press.

Baumgartner, Frank R., Bryan D. Jones and Michael C. Rosentiehl. 1997. "The Co-Evolution of Issues and Structures in Congress." Working Paper \#2. Center for American Politics and Public Policy, Department of Political Science, University of Washington. August.

Becker, Gary S. 1983. “A Theory of Competition among Pressure Groups for Political Influence”. Quarterly Journal of Economics. 98:371-400.

Biskupic, Joan. 1994. “Justices Broaden Property Rights.” Washington Post. June 25:A1. 
Blaesser, Brian W., Clyde W. Forrest, Douglas W. Kmiec, Daniel R. Mandelker, Alan C. Weinstein, and Norman Williams, Jr. 1989. Land Use and the Constitution. Chicago: Planners Press.

Block, Larry. May 6, 1999. Telephone Interview.

Boeckelman, Keith. 1992. “The Influence of States on Federal Policy Adoptions.” Policy Studies Journal. 20:365-375.

Bork, Robert. 1989. The Wall Street Journal, October 13.

Bosso, Christopher J. 1987. Pesticides and Politics: The life Cycle of a Public Issue. Pittsburgh: University of Pitsburgh Press.

Brick, Phil. 1995. "Determined Opposition: The Wise Use Movement Challenges Environmentalism”. Environment. 37:8:17+.

Brown, Judy. May 5, 1999. Telephone Interview.

Brown, William P. 1995. Issues, Interests, and Places in a Postreform Congress: Agriculture's Policy Domain. Lawrence: University Press of Kansas.

Bullard, Robert, ed. 1993. Confronting Environmental Racism: Views from the Grassroots. Boston: South End Press.

Byrnes, Patricia. 1992. “The Counterfeit Crusade.” Wilderness. Vol.56, no.198, Summer: 29-31.

Byrnes, Patricia. 1995. “Are We Being Taken by Takings?” Wilderness Watch. Spring, vol.58:45.

Carlin, Alan, Paul F. Scodari, and Don H. Garner. 1992. "Environmental Investments: The Costs of Cleaning Up.” Environment, vol.34, no.2, March: 12-20, 38-44.

Carson, Ed. 1996. "Property Frights: Why Property Rights Initiatives Are Losing at the Polls." Reason Magazine, May: 27-31.

Ceplo, Karol J. 1995. "Land-Rights Conflicts in the Regulation of Wetlands," in Land Rights, ed. Bruce Yandle. Lanham, M.D.: Rowman \& Littlefield Publishers.

Chomski, Joseph M. and Constance E. Brooks. 1980. The Sagebrush Rebellion: A Concise Analysis of the History, the Law and Politics of Public Land in the United States. Alaska: Legislative Affairs Agency. 
Clean Air Act. 42 U.S.C., 7401-7671q, (1988 and supp. 1991).

Cobb, Roger W. and Charles D. Elder. 1983. Participation in American Politics: The Dynamics of Agenda Building. Baltimore: John Hopkins University Press.

Cobb, Roger and Mark Howard Ross, eds. 1997. Cultural Strategies of Agenda Denial: Avoidance, Attack and Redefinition. Lawrence: University Press of Kansas.

Cobb, Roger, Jennie-Keith Ross, and Marc Howard Ross. 1976. "Agenda Building as a Comparative Political Process". American Political Science Review. 70:126-38.

Cohen, Michael, James March, and Johan Olsen. 1972. “A Garbage Can Model of Organizational Choice". Administrative Science Quarterly. 17:1-25.

Cordes, Mark W. 1997. "Leapfrogging the Constitution: The Rise of State Takings Legislation." Ecology Law Quarterly. 24:187-242.

Delaney, John J. 1993. “Advancing Private Property Rights: the Lessons of Lucas.” Stetson Law Review. 22:395-408.

DiGregorio, Christine. 1992. "Leadership Approaches in Congressional Committee Hearings." Western Political Quarterly. 45:971-83.

Downs, Anthony. 1972. "Up and Down With Ecology: The Issue Attention Cycle”. Public Interest. 28:38-50

Dowie, Mark. 1995. Losing Ground: American Environmentalism at the Close of the Twentieth Century. Cambridge: MIT Press.

Dunlap, Riley E. 1987.’Polls, Pollution, and Politics Revisited: Public Opinion on the Environment in the Reagan Era." Environment. 29: no.6: 6-11, 32-37.

Dunlap, Thomas R. 1988. Saving America’s Wildlife. Princeton: Princeton University Press.

Dunlap, Riley E. 1991. "Trends in Public Opinion." In American Environmentalism: The US Environmental Movement, 1970-1990. Ed. Riley E. Dunlap and Angela G. Mertig. Philadelphia: Taylor and Francis.

Dunlap, Riley E. 1995. "Public Opinion and Environmental Policy," in Environmental Politics and Policy: Theories and Evidence, $2^{\text {nd }} e d$., ed. James P. Lester. Durham: Duke University Press. 
Dye, Thomas. 1990. American Federalism: Competition Among Governments. Lexington, Mass.: Lexington Books.

Ebell, Myron. May 10, 199. Telephone Interview.

Ehrlich, Paul. 1968. The Population Bomb. New York: Ballentine.

Eisenberg, Gary. 1988. "Property: The Takings Clause of the Fifth Amendment." Annual Survey of American Law. September: 1105-1135.

Endangered Species Act. 1973. 16 U.S.C., p. 1532 (1988).

Epstein, Richard. 1985. Takings: Private Property and the Power of Eminent Domain. Cambridge, MA: Harvard University Press.

Eyestone, Robert. 1978. From Social Issues to Public Policy. New York: John Wiley and Sons.

Fellows, James A. 1996. “The Legal Doctrine of Regulatory Takings: An Evolving Issue.” The Appraisal Journal. 64:363-374.

Fenno, Richard F. Jr. 1966. The Power of the Purse: Appropriations Politics in Congress. Boston: Little, Brown.

Fenno, Richard F. Jr. 1973. Congressmen in Committees. Boston: Little, Brown.

Freilich, Robert H. and Elizabeth A. Garvin. 1993. "Takings After Lucas: Growth Management, Planning, and Regulatory Implementation Will Work Better Than Before.” Stetson Law Review, 22:409-434.

Froman, Lewis. 1967. The Congressional Process: Styles, Rules and Procedures. Boston: Little, Brown.

Gillroy, John M. and Robert Y. Shapiro. 1986. “The Polls: Environmental Protection”. Public Opinion Quarterly 50. 2: 270-276.

Gottleib, Alan, ed. The Wise Use Agenda. Bellevue, WA.: Free Enterprise Press.

Gray, Virginia. 1994. "Competition, Emulation, and Policy Innovation”. In New Perspectives on American Politics, eds. Lawrence C. Dodd and Calvin Jillson. Washington D.C.: CQ Press.

Greenhouse, Linda. 1992. "Justices Ease Way to Challenge Land-Use Rules That Prevent Development.” New York Times. June 30: A18. 
Greenhouse, Linda. 1994. "Revisiting Property Rights: Court Still Seems on the Fence.” New York Times. March 24: A11.

Greider, William. 1992. Who Will Tell the People: The Betrayal of American Democracy. New York: Simon and Schuster.

Griffith, Ernest S. 1951. Congress: Its Contemporary Role. New York: New York University Press.

Grossman, Karl. 1994. "The People of Color Environmental Summit," in Unequal Protection, ed. Robert Bullard. San Francisco: Sierra Club.

Hahn-Baker, David. 1994. "Rocky Roads to Consensus: Traditional Environmentalism Meets Environmental Justice". Amicus Journal 16: 41-43, Spring.

Hall, Richard L. "Participation, Abdication, and Representation in Congressional Committees." In Congress Reconsidered, ed. Lawrence C. Dodd and Bruce I. Oppenheimer. $5^{\text {th }}$ ed. Washington, DC: Congressional Quarterly.

Harris, Louis. 1989. "Public Worried About State of the Environment Today and in the Future. Harris Poll. 21: 1-4.

Hayes, Michael T. 1986. “The New Group Universe” in Interest Group Politics, $2^{\text {nd }}$ ed., ed. Cigler and Loomis. Washington D.C.: CQ Press.

Hays, Samuel P. 1987. Beauty, Health, and Permanence: Environmental Politics in the United States, 1955-1985. Cambridge, England: Cambridge University Press.

Helvarg, David. 1994. “The Anti-Enviros Are Getting Uglier.” The Nation, vol.259, November 28.

Helvarg, David. 1994. War Against the Greens: The "Wise Use Movement," The New Right, and Anti-Environmental Violence. San Francisco: Sierra Books.

Hinckley, Barbara. 1971. Stability and Change in Congress. New York: Harper and Row.

Hoerner, Andrew J. 1995. “Life and Taxes.” The Amicus Journal. Summer:14-17.

Holusha, John. 1988. "Bush Pledges Aid for Environment.” New York Times, September 1.

Hopkins, Thomas D. 1991. Cost of Regulation. Rochester, New York: Rochester Institute of Technology. 
Jones, Bryan D., Frank Baumgartner, and Jeffery C. Talbert. 1993. "The Destruction of Issue Monopolies in Congress.” American Political Science Review 87:657-71.

Jones, Charles O. 1995. "Campaigning to Govern: The Clinton Style," in The Clinton Presidency: The First Appraisals, ed. Colin Campbell and Bert Rockman. Chatham, N.J.: Chatham House.

Jones, Charles O., and Randall Strahan. 1985. "The Effect of Energy Politics on Congressional and Executive Organization in the 1970s." Legislative Studies Quarterly 10:151-79.

Kelman, Steven. 1987. Making Public Policy. New York: Basic Books.

Kenworthy, Tom, and Kirtin Downey. 1992. "South Carolina May Have to Pay Compensation in Property Case." Washington Post (June 30):A10.

King, David C. 1991. "Congressional Committee Jurisdictions and the Consequences of Reforms." Paper Presented at the Annual Meeting of the Midwest Poli Science Association, Chicago, Ill. 18-20, April.

King, David C. 1992. "Committee Jurisdictions and Institutional Change in the House of Representatives.” Ph.D. dissertation, University of Michigan.

King, Paula J. 1988. "Policy Entrepreneurs: Catalysts in the Policy Innovation Process.” Ph.D. dissertation: University of Minnesota.

Kingdon, John W. 1984. Agendas, Alternatives, and Public Policies. Boston: Little, Brown, and Company.

Kingdo n, John W. 1995. Agendas, Alternatives, and Public Policies: $2^{\text {nd }}$ ed. New York, NY.: Harper Collins College Publishers.

Kmiec, Douglas W. March 1997. "Inserting the Last Remaining Pieces into the Takings Puzzle." William and Mary Law Review. 38:995-1046.

Knickerbocker, Brad. 1993. "Property Rights Movement Gains Ground in Congress." Christian Science Monitor. September 21: 1+

Knox, Margaret L. 1993. “The World According to Cushman.” Wilderness, vol.56, no.200:28.

Krehbiel, Keith. 1991. Information and Legislative Organization. Ann Arbor: University of Michigan Press. 
Krehbiel, Keith, Kenneth A. Shepsle, and Barry R. Weingast. 1987. "Why Are Congressional Committees Powerful?” American Political Science Review 81:929-45.

Kriz, Margaret. 1993. “Land Mine.” National Journal 25. October 23: 2531-34.

Larson, Stephanie and David Grier. 1990. "Agenda Setting and AID S". Paper prepared for presentation at the annual meeting of the American Political Science Association, San Francisco, California, August 29-September 2.

Latham, Earl. 1952. The Group Basis of Politics. Ithica, NY.: Cornell University Press.

Lavelle, Marianne. 1995. "Activist Counties Battle the Federal Government Over Land Use Controls." National Law Journal, vol.7, no.4, June 5.

Leyden, Kevin. 1995. "Interest Group Resources and Testimony at Congressional Hearings." Legislative Studies Quarterly. 20:431-439.

Light, Paul C. 1982. The President's Agenda. Baltimore: John Hopkins University Press.

Limbaugh, Rush N. 1992. The Way Things Ought to Be. New York: Pocket Books.

Lipford, Jody and Donald J. Boudreaux. 1995. "The Political Economy of State Takings Legislation," in Land Rights: The 1990's Property Rights Rebellion, ed. Bruce Yandle. Lanham, MD.: Rowman and Littlefield Publishers, INC.

Lund, Hertha L. January 1995. "Property Rights Legislation in the States: A Review". PERC Policy Series, Issue Number PS-1. Http://www.imt.net/ perc/ps1.htm

Lyons, Cody. May 5, 1999. Telephone Interview.

Majone, Giandomenico. 1988. "Policy Analysis and Public Deliberation." In The Power of Public Ideas, Ch. 7, ed. Robert B. Reich. Cambridge, MA: Harvard University Press.

Mann, Eric. 1990. "Environmentalism in the Corporate Climate." Tikkun, Vol.5, No.2, February.

Marzulla, Nancie G. 1995. "The Property Rights Movement: How It Began and Where It Is Headed," in Land Rights: The 1990s' Property Rights Rebellion, ed. Bruce Yandle. Lanham, MD.: Rowman and Littlefield.

Marzulla, Roger J. 1988. “The New Takings Executive Order and Environmental Regulation Collision or Cooperation?" Environmental Law Reporter. July: 10254-60. 
McCutcheon, Chuck et al. 1996. "Lott Tells Lobbyists Property Rights Bill is Dead for This Year.” CQ Monitor. September 9:5.

McFarland, Andrew S. 1991. "Interest Groups and Political Time: Cycles in America." British Journal of Political Science. 21:257-284.

Mintrom, Michael. 1997. "Policy Entrepreneurs and the Diffusion of Innovation". American Journal of Political Science. 41:738-770.

Mitchell, Robert Cameron. 1984. "Public Opinion and Environmental Politics in the 1970s and 1980s," in Environmental Policy in the 1980s: Reagan's New Agenda, p.51-74. Eds., Norman J. Vig and Michael E. Kraft. Washington, DC: CQ Press.

Mitchell, Robert, Angela Mertig, and Riley Dunlap. 1985. "National Environmental Organizations." Society and Natural Resources, Vol.4.

Moffett, Randolph R. 1996. "Regulatory Takings: Lobbying, Coalitions, and Influence". Ph.D. dissertation: West Virginia University.

Morin, Richard. 1995. “A Lighter Shade of Green”. Washington Post National Weekly Edition. June 5-11, p.37.

Moulton, Barbara. 1995. “Takings Legislation: Protection of Property Rights or Threat to the Public Interest?" Environment. March, vol.37, no.2:44-45.

O’Keefe, Michael, and Kevin Daley. 1993. "Checking the Right." Buzzworm, The Environmental Journal. Vol.5, no.3, May/June.

Paehlke, Robert. 1989. Environmentalism and the Future of Progressive Politics. New Haven: Yale University Press.

Pennsylvania Coal v. Mahon, 260 US 393, 416. 1922.

Peters, B. Guy, and Brian W. Hogwood. 1985. "In Search of the Issue Attention Cycle." Journal of Politics. 47:239-53.

Pinchot, Gilford. 1947. Breaking New Ground. New York: Harcourt, Brace.

Plotkin, Sidney. 1987. Keep Out: The Struggle for Land Use Control. Berkely, CA.: University of California Press.

Polsby, Nelson W. 1984. Policy Innovation in America: The Politics of Policy Innovation. New Haven: Yale University Press. 
Rabe, Barry G. 1997. "Power to the States: The Promise and Pitfalls of Decentralization," in Environmental Policy in the 1990s, eds. Norman J. Vig and Michael E. Kraft. Washington D.C.: CQ Press

Ray, Dixy Lee and Lou Guzzo. 1993. Environmental Overkill: Whatever Happened to Common Sense? Washington D.C.: Regnery Gateway.

Riker, William. 1986. The Art of Political Manipulation. New Haven: Yale University Press.

Ringquist, Evan J. 1997. "Environmental Justice: Normative Concerns and Empirical Evidence," in Environmental Policy in the 1990s, eds. Norman J. Vig and Michael E. Kraft. Washington D.C.: CQ Press.

Rosenbaum, Walter A. 1995. Environmental Politics and Policy. Washington DC: CQ Press.

Rosenbaum, Walter A. 1998. Environmental Politics and Policy: $4^{\text {th }}$ ed. Washington DC: CQ Press.

Sabatier, Paul A. and Hank C. Jenkins-Smith. 1993. Policy Change and Learning: An Advocacy Coalition Approach. Boulder: Westview Press.

Salisbury, David F. 1981. "Energy: The Varmit That May Spoil America's West." The Christian Science Monitor. September, 3, 1981, p.B26.

Sax, Joseph L. 1971. "Takings, Private Property and Public Rights." The Yale Law Journal. $81: 149+$

Sax, Joseph L. 1996. “Takings Legislation: Where it Stands and What Is Next.” Ecology Law Quarterly. 23:509-520.

Schattschneider, E. E. 1960. The Semisoveriegn People: A Realist's View of Democracy in America. New York: Holt, Rinehart, and Winston.

Schlesinger, Arthur M. Jr. 1986. The Cycles of American History. Boston: Houghton Mifflin.

Schmidt, John R. 1995. Statement of John R. Schmidt, Associate Attorney General,Before the Committee on the Judiciary, United States Senate. $104^{\text {th }}$ Congress, $1^{\text {st }}$ Session, 10.

Shabecoff, Philip. 1993. A Fierce Green Fire. New York: Hill and Wang.

Shepsle, Kenneth A. 1978. The Giant Jigsaw Puzzle. Chicago: University of Chicago Press. 
Shepsle, Kenneth A. 1979. "Institutional Arrangements and Equilibrium in Multidimensional Voting Models.” American Journal of Political Science 23:27-60.

Short, Brant C. 1989. Ronald Reagan and the Public Lands: America's Conservation Debate. College Station: Texas A \&M University Press.

Smith, James A. 1991. The Idea Brokers. New York: Free Times Press.

Smith, Steven S., and Christopher Deering. 1990. Committees in Congress. Washington, DC: Congressional Quarterly.

Smith, Zachary A. 1995. The Environmental Policy Paradox, $2^{\text {nd }}$ ed. Englewood Cliffs, N.J.: Prentice Hall, Inc.

Snider, MacWilliams Cosgrove. 1993. The Wise Use Movement: Strategic Analysis and the Fifty State Review. Washington, D.C.: Environmental Working Group. March:1,27.

Steinhart, Carol, and John Steinhart. 1972. Blowout: A Case Study of the Santa Barbara Oil Spill. Belmont, CA: Wadsworth.

Switzer, Jacqueline Vaughn. 1997. Green Backlash. Lynne Reiner Publishers, Boulder.

Switzer, Jacqueline Vaughn. 1994. Environmental Politics: Domestic and Global Dimensions. New York: St. Martin's Press.

Symons, Lee P. 1988. "Property Rights and Local Land Use Regulation: The Implications of First English and Nollan." Publius 18: 81-95.

Talbert, Jeffery C., Bryan D. Jones, and Frank R. Baumgartner. 1995. "Nonlegislative Hearings and Policy Change in Congress.” American Journal of Political Science 39:383-406.

Teifer, Charles. 1994. The Semi-Sovereign Presidency. Boulder: Westview.

Treanor, William Michael. March 1997. "The Armstrong Principle, the Narratives of Takings, and Compensation Statutes.” William and Mary Law Review. 38:1151-1176.

Truman, David. 1951. The Governmental Process. New York: Alfred A. Knopf.

U.S. Environmental Protection Agency, 1990. Environmental Investments: The Costs of a Clean Environment. EPA-230-11-90-083, November. Washington D.C.: EPA. 
Vig, Norman J. 1997. "Presidential Leadership and the Environment: From Reagan to Clinton," in Environmental Policy in the 1990s, $3^{\text {rd }}$ ed., eds. Norman J. Vig and Michael E. Kraft. Washington D.C.: Congressional Quarterly Press.

Walker, Jack L. 1969. “The Diffusion of Innovations Among the American States.” American Political Science Review. 63:880-899.

Walker, Jack L. 1991. Mobilizing Interest Groups in America: Patrons, Professions, and Social Movements. Ann Arbor, MI: The University of Michigan Press.

Wasylik, Alex Michael. June 19, 1998. Author's Interview, Washington, D.C.

Welch, Lee Ann. 1995. "Property Rights Conflicts Under the Endangered Species Act: Protection of the Red-Cockaded Woodpecker," in Land Rights, ed. Bruce Yandle. Lanham M.D.: Rowman \& Littlefield Publishers.

Wenner, Lettie McSpadden and Lee E. Dutter. 1988. "Contextual Influences on Court Outcomes." Western Political Quarterly. 41:415-434.

Wicker, Thomas. 1994. "Waiting for an Environmental President." Audubon, September October.

Wise, Charles, R. 1992. "The Changing Doctrine of Regulatory Taking and the Executive Branch." Administrative Law Review. Spring, vol.44:404.

Worsham, Jeffrey. 1997. Other People's Money: Policy Change, Congress, and Bank Regulation. Boulder: Westview Press.

Worsham, Jeffrey. 1998. "Wavering Equilibriums: Subsystem Dynamnics and Agenda Control." American Politics Quarterly. October: 485-512.

Worsham, Jeffrey. 1998. "Ain't Nobody's Business If I Do: Turf Control in Congressional Committees." Presented at the annual meeting of the American Political Science Association, Boston, MA, September 3-6.

Young, Garry, and Joseph Cooper. 1993. "Multiple Referral and the Transformation of House Decision Making." In Congress Reconsidered, $5^{\text {th }}$ ed., ed. Lawrence C. Dodd and Bruce I. Oppenheimer. Washington: Congressional Quarterly. 
Appendix 1: Introduced Federal Property Rights Legislation, 1977-1998

\begin{tabular}{|c|c|c|c|c|c|c|c|}
\hline Title & Bill \# & Type $^{\mathrm{a}}$ & Date $^{b}$ & Sponsor & Referral Committee(s) & Referral Subcommittee(s) & Final Action \\
\hline \multicolumn{8}{|c|}{$95^{\text {th }}$ Congress, $1977-1978$} \\
\hline $\begin{array}{l}\text { Big Thicket National } \\
\text { Preserve Act }\end{array}$ & H.R.2544 & EDC & $1 / 26 / 77$ & $\begin{array}{l}\text { Rep. Wilson, } \\
\text { C.H. }\end{array}$ & $\begin{array}{l}\text { House Interior and Insular } \\
\text { Affairs }\end{array}$ & & None \\
\hline $\begin{array}{l}\text { Joint Resolution to designate } \\
\text { the third week in April each } \\
\text { year as "National Private } \\
\text { Property Week" }\end{array}$ & H.J.Res.261 & $S$ & $2 / 16 / 77$ & Rep. Spellman & $\begin{array}{c}\text { House Post Office and Civil } \\
\text { Service }\end{array}$ & & None \\
\hline $\begin{array}{l}\text { Bill to provide } \\
\text { reimbursement... to real } \\
\text { property owners... of } \\
\text { litigation expenses arising } \\
\text { from the condemnation of } \\
\text { real property... by the } \\
\text { National Park Service }\end{array}$ & H.R.8215 & EDC & $7 / 12 / 77$ & Rep. Brodhead & $\begin{array}{c}\text { House Government Operations } \\
\text { House Public Works and } \\
\text { Transportation }\end{array}$ & & $\begin{array}{l}\text { Referred to House Public Works and } \\
\text { Transportation committee }\end{array}$ \\
\hline $\begin{array}{l}\text { Bill to Amend the Uniform } \\
\text { Relocation Assistance and } \\
\text { Real Property Acquisition } \\
\text { Policies Act of } 1970\end{array}$ & H.R.9387 & EDC & $9 / 30 / 77$ & Rep. Andrews & $\begin{array}{l}\text { House Public Works and } \\
\text { Transportation }\end{array}$ & & None \\
\hline $\begin{array}{l}\text { Bill to Amend the Uniform } \\
\text { Relocation Assistance and } \\
\text { Real Property Acquisition } \\
\text { Policies Act of } 1970\end{array}$ & H.R.9772 & EDC & $10 / 27 / 77$ & Rep. Andrews & $\begin{array}{l}\text { House Public Works and } \\
\text { Transportation }\end{array}$ & & None \\
\hline $\begin{array}{l}\text { Bill to Amend the Uniform } \\
\text { Relocation Assistance and } \\
\text { Real Property Acquisition } \\
\text { Policies Act of } 1970\end{array}$ & H.R.10122 & EDC & $11 / 29 / 77$ & Rep. Andrews & $\begin{array}{l}\text { House Public Works and } \\
\text { Transportation }\end{array}$ & & None \\
\hline \multicolumn{8}{|c|}{$96^{\text {th }}$ Congress, 1979-1980 } \\
\hline $\begin{array}{c}\text { Uniform Relocation } \\
\text { Assistance Act Amendments } \\
\text { of } 1979\end{array}$ & S.1108 & EDC & $5 / 9 / 79$ & Sen. Sasser & Senate Governmental Affairs & Ssc Intergovernmental Relations & $\begin{array}{l}\text { Referred to Senate subcommittee on } \\
\text { Intergovernmental Relations }\end{array}$ \\
\hline
\end{tabular}


Appendix 1 (Continued)

\begin{tabular}{|c|c|c|c|c|c|c|c|}
\hline Title & Bill \# & Type $^{\mathrm{a}}$ & Date $^{\mathrm{b}}$ & Sponsor & Referral Committee(s) & Referral Subcommittee(s) & Final Action \\
\hline $\begin{array}{l}\text { Bill to acquire certain lands } \\
\text { so as to assure the } \\
\text { preservation and protection } \\
\text { of the Potomac River } \\
\text { Shoreline }\end{array}$ & H.R.4947 & EDC & $7 / 24 / 79$ & Rep. Stark & House District of Columbia & Hsc Metropolitan Affairs & $\begin{array}{l}\text { Referred to House subcommittee on } \\
\text { Metropolitan Affairs }\end{array}$ \\
\hline $\begin{array}{l}\text { Uniform Relocation } \\
\text { Assistance Act Amendments } \\
\text { of } 1980\end{array}$ & H.R.6256 & EDC & $1 / 22 / 80$ & Rep. Schroeder & $\begin{array}{l}\text { House Public Works and } \\
\text { Transportation }\end{array}$ & Hsc Surface Transportation & $\begin{array}{l}\text { Referred to House subcommittee on } \\
\text { Surface Transportation }\end{array}$ \\
\hline $\begin{array}{c}\text { Uniform Relocation } \\
\text { Assistance Act Amendments } \\
\text { of } 1980\end{array}$ & H.R.6463 & EDC & $2 / 7 / 80$ & Rep. Mineta & $\begin{array}{l}\text { House Public Works and } \\
\text { Transportation }\end{array}$ & Hsc Surface Transportation & $\begin{array}{l}\text { Referred to House subcommittee on } \\
\text { Surface Transportation }\end{array}$ \\
\hline $\begin{array}{c}\text { Uniform Relocation } \\
\text { Assistance Act Amendments } \\
\text { of } 1979\end{array}$ & H.R.6756 & EDC & $3 / 10 / 80$ & Rep. Wolff & $\begin{array}{l}\text { House Public Works and } \\
\text { Transportation }\end{array}$ & Hsc Surface Transportation & $\begin{array}{l}\text { Referred to House subcommittee on } \\
\text { Surface Transportation }\end{array}$ \\
\hline $\begin{array}{l}\text { Bill to Amend the Uniform } \\
\text { Relocation Assistance and } \\
\text { Real Property Acquisition } \\
\text { Policies Act of } 1970\end{array}$ & H.R.8141 & EDA & $9 / 17 / 80$ & Rep. Ullman & $\begin{array}{l}\text { House Public Works and } \\
\text { Transportation }\end{array}$ & Hsc Surface Transportation & $\begin{array}{l}\text { Executive statement requested from } \\
\text { DOT, GSA, Interior, OMB. }\end{array}$ \\
\hline $\begin{array}{l}\text { Bill to Amend the Uniform } \\
\text { Relocation Assistance and } \\
\text { Real Property Acquisition } \\
\text { Policies Act of } 1970\end{array}$ & H.R.8208 & EDC & $9 / 24 / 80$ & Rep. Volkmer & $\begin{array}{l}\text { House Public Works and } \\
\text { Transportation }\end{array}$ & Hsc Surface Transportation & $\begin{array}{l}\text { Referred to House subcommittee on } \\
\quad \text { Surface Transportation }\end{array}$ \\
\hline $\begin{array}{l}\text { Bill to compensate } \\
\text { individuals for land taken by } \\
\text { the federal government } \\
\text { pursuant to the American- }\end{array}$ & H.R.8304 & EDC & $10 / 2 / 80$ & Rep. Roybal & House Judiciary & $\begin{array}{l}\text { Hsc Administrative Law and } \\
\text { Governmental Relations }\end{array}$ & $\begin{array}{c}\text { Referred to House subcommittee on } \\
\text { Administrative Law and Government } \\
\text { Relations }\end{array}$ \\
\hline
\end{tabular}


Appendix 1 (Continued)

\begin{tabular}{|c|c|c|c|c|c|c|c|}
\hline Title & Bill \# & Type $^{\mathrm{a}}$ & Date $^{\mathrm{b}}$ & Sponsor & Referral Committee(s) & Referral Subcommittee(s) & Final Action \\
\hline \multicolumn{8}{|c|}{$97^{\text {th }}$ Congress, 1981-1982 } \\
\hline $\begin{array}{l}\text { Bill for the relief of the prior } \\
\text { owners of the Harris Neck } \\
\text { Wildlife Refuge, or their } \\
\text { heirs }\end{array}$ & H.R.1044 & EDC & $1 / 22 / 81$ & Rep. Ginn & House Judiciary & $\begin{array}{l}\text { Hsc Administrative Law and } \\
\text { Governmental Relations }\end{array}$ & $\begin{array}{c}\text { Referred to House subcommittee on } \\
\text { Administrative Law and Government } \\
\text { Relations }\end{array}$ \\
\hline $\begin{array}{c}\text { Uniform Relocation } \\
\text { Assistance Act Amendments } \\
\text { of } 1981\end{array}$ & H.R.1529 & EDC & $2 / 2 / 81$ & Rep. Edwards & $\begin{array}{l}\text { House Public Works and } \\
\text { Transportation }\end{array}$ & Hsc Surface Transportation & $\begin{array}{l}\text { Referred to House subcommittee on } \\
\text { Surface Transportation }\end{array}$ \\
\hline $\begin{array}{l}\text { Bill to Amend the Federal } \\
\text { Rules of Civil Procedure }\end{array}$ & H.R.3691 & EDC & $5 / 21 / 81$ & Rep. Whitten & House Judiciary & Hsc Criminal Justice & $\begin{array}{l}\text { Referred to House subcommittee on } \\
\text { Criminal Justice }\end{array}$ \\
\hline $\begin{array}{c}\text { Uniform Relocation } \\
\text { Assistance Act Amendments } \\
\text { of } 1981\end{array}$ & S.2363 & EDC & $4 / 13 / 82$ & $\begin{array}{c}\text { Sen. } \\
\text { Durenberger }\end{array}$ & Sen. Governmental Affairs & Ssc Intergovernmental Relations & Passed Senate (8/5/82) \\
\hline $\begin{array}{c}\text { Uniform Relocation } \\
\text { Assistance and Real Property } \\
\text { Acquisition Policies Act } \\
\text { Amendments of } 1982\end{array}$ & H.R.6171 & EDC & $4 / 27 / 82$ & Rep. Howard & $\begin{array}{l}\text { House Public Works and } \\
\text { Transportation }\end{array}$ & Hsc Surface Transportation & $\begin{array}{l}\text { Referred to House subcommittee on } \\
\text { Surface Transportation }\end{array}$ \\
\hline \multicolumn{8}{|c|}{$98^{\text {th }}$ Congress, 1983-1984 } \\
\hline $\begin{array}{l}\text { Uniform Relocation Act } \\
\text { Amendments of } 1983\end{array}$ & S.531 & EDC & $2 / 17 / 83$ & $\begin{array}{c}\text { Sen. } \\
\text { Durenberger }\end{array}$ & $\begin{array}{c}\text { Senate Governmental Affairs } \\
\text { House Public Works and } \\
\text { Transportation }\end{array}$ & Hsc Surface Transportation & $\begin{array}{c}\text { Passed Senate }(5 / 20 / 83) \text { and referred to } \\
\text { House subcommittee on Surface } \\
\text { Transportation }\end{array}$ \\
\hline $\begin{array}{l}\text { Bill to Amend the Uniform } \\
\text { Relocation Assistance and } \\
\text { Real Property Acquisition } \\
\text { Policies Act of } 1970\end{array}$ & H.R.1687 & EDC & $2 / 25 / 83$ & Rep. Howard & $\begin{array}{l}\text { House Public Works and } \\
\text { Transportation }\end{array}$ & Hsc Surface Transportation & $\begin{array}{l}\text { Referred to House subcommittee on } \\
\quad \text { Surface Transportation }\end{array}$ \\
\hline
\end{tabular}


Appendix 1 (Continued)

\begin{tabular}{|c|c|c|c|c|c|c|c|}
\hline Title & Bill \# & Type $^{\text {a }}$ & Date $^{b}$ & Sponsor & Referral Committee(s) & Referral Subcommittee(s) & Final Action \\
\hline $\begin{array}{l}\text { Bill to Amend the Federal } \\
\text { Rules of Civil Procedure }\end{array}$ & H.R.1828 & EDC & $3 / 2 / 83$ & Rep. Whitten & House Judiciary & Hcs Criminal Justice & $\begin{array}{l}\text { Referred to House subcommittee on } \\
\text { Criminal Justice }\end{array}$ \\
\hline $\begin{array}{l}\text { Bill to compensate... ranchers } \\
\text { for ranching units taken by } \\
\text { the Department of the Army } \\
\text { for the White Sands Missile } \\
\text { Range, NM }\end{array}$ & H.R.4022 & EDC & $9 / 28 / 83$ & Rep. Skeen & House Judiciary & $\begin{array}{l}\text { Hsc Administrative Law and } \\
\text { Governmental Relations }\end{array}$ & $\begin{array}{c}\text { Referred to House subcommittee } \\
\text { Administrative Law and Governmental } \\
\text { Relations }\end{array}$ \\
\hline $\begin{array}{l}\text { Bill to restore the right to a } \\
\text { jury trial in certain cases } \\
\text { involving the exercise by the } \\
\text { government of the power of } \\
\text { eminent domain }\end{array}$ & H.R.6107 & EDC & $8 / 8 / 84$ & Rep. Whitten & House Judiciary & Hsc Criminal Justice & $\begin{array}{l}\text { Referred to House subcommittee on } \\
\text { Criminal Justice }\end{array}$ \\
\hline $\begin{array}{l}\text { Bill to restore the right to a } \\
\text { jury trial in certain cases } \\
\text { involving the exercise by the } \\
\text { government of the power of } \\
\text { eminent domain }\end{array}$ & H.R.6127 & EDC & $8 / 9 / 84$ & Rep. Whitten & House Judiciary & Hsc Criminal Justice & $\begin{array}{l}\text { Referred to House subcommittee on } \\
\text { Criminal Justice }\end{array}$ \\
\hline
\end{tabular}

$99^{\text {th }}$ Congress, 1985-1986

$\begin{array}{ccccccc}\begin{array}{c}\text { Uniform Relocation Act } \\ \text { Amendments of 1985 }\end{array} & \text { S.249 } & \text { EDC } & 1 / 22 / 85 & \begin{array}{c}\text { Sen. } \\ \text { Durenberger }\end{array} & \begin{array}{c}\text { Senate Governmental Affairs } \\ \text { Ssc Intergovernmental Relations }\end{array} \\ \begin{array}{c}\text { Declaration of Taking } \\ \text { Amendments Act of 1986 }\end{array} & \text { H.R.4586 } & \text { EDC } & 4 / 15 / 86 & \text { Rep. Fish } & \text { House Judiciary } & \begin{array}{c}\text { Hsc Administrative Law and } \\ \text { Governmental Relations }\end{array} \\ \text { Bill to amend the interest } & \text { S.2424 } & \text { EDC } & 5 / 8 / 86 & \text { Sen. Thurmond } & \text { Senate Judiciary } & \text { Sdministrative Law and Governmental } \\ \text { Relations }\end{array}$

S.2424

EDC $\quad 5 / 8 / 86$

Sen. Thurmond

Senate Judiciary

Ssc Courts

Indefinitely postponed by Senate

of Taking Act 
Appendix 1 (Continued)

\begin{tabular}{|c|c|c|c|c|c|c|c|}
\hline Title & Bill \# & Type $^{\mathrm{a}}$ & Date $^{\text {b }}$ & Sponsor & Referral Committee(s) & Referral Subcommittee(s) & Final Action \\
\hline $\begin{array}{l}\text { Bill to amend the interest } \\
\text { provisions of the Declaration } \\
\text { of Taking Act }\end{array}$ & H.R.5363 & EDC & $11 / 14 / 86$ & Rep. Glickman & House Judiciary & $\begin{array}{l}\text { Hsc Administrative Law and } \\
\text { Governmental Relations }\end{array}$ & Became Public Law No: 99-656 \\
\hline \multicolumn{8}{|c|}{$101^{s t}$ Congress, 1989-1990 } \\
\hline $\begin{array}{l}\text { White Sands Fair } \\
\text { Compensation Act of } 1989\end{array}$ & H.R.3408 & EDC & $10 / 4 / 89$ & Rep. Skeen & House Judicicary & $\begin{array}{l}\text { Hsc Administrative Law and } \\
\text { Governmental Relations }\end{array}$ & $\begin{array}{c}\text { Referred to House subcommittee on } \\
\text { Administrative Law and Governmental } \\
\text { Relations }\end{array}$ \\
\hline $\begin{array}{c}\text { White Sands Fair } \\
\text { Compensation Act of } 1989\end{array}$ & S.1725 & EDC & $10 / 4 / 89$ & Sen. Domenici & Senate Judiciary & $\begin{array}{l}\text { Ssc Courts and Administrative } \\
\text { Practice }\end{array}$ & $\begin{array}{l}\text { Referred to Senate subcommittee on } \\
\text { Courts and Administrative Practice }\end{array}$ \\
\hline \multicolumn{8}{|c|}{$102^{\text {nd }}$ Congress, 1991-1992 } \\
\hline $\begin{array}{l}\text { Private Property Rights Act } \\
\text { of } 1991\end{array}$ & S.50 & TA & $1 / 14 / 91$ & Sen. Symms & Senate Governmental Affairs & & $\begin{array}{l}\text { Referred to Senate Governmental } \\
\text { Affairs committee }\end{array}$ \\
\hline Property Rights Act of 1991 & H.R.905 & TA & $2 / 6 / 91$ & Rep. McEwen & House Government Operations & $\begin{array}{l}\text { Hsc Legislation and National } \\
\text { Security }\end{array}$ & $\begin{array}{l}\text { Referred to House subcommittee on } \\
\text { Legislation and National Security }\end{array}$ \\
\hline $\begin{array}{c}\text { Private Property Rights Act } \\
\text { of } 1991\end{array}$ & H.R.1572 & TA & $3 / 21 / 91$ & Rep. Olin & $\begin{array}{l}\text { House Judiciary } \\
\text { House Agriculture }\end{array}$ & $\begin{array}{l}\text { Hsc Department Operations, } \\
\text { Research, and Foreign Agriculture } \\
\text { Hsc Administrative Law and } \\
\text { Governmental Relations }\end{array}$ & $\begin{array}{c}\text { Referred to House subcommittee on } \\
\text { Administrative Law and Governmental } \\
\text { Relations }\end{array}$ \\
\hline $\begin{array}{c}\text { Private Property Rights Act } \\
\text { of } 1991\end{array}$ & H.R.1650 & TA & $3 / 22 / 91$ & Rep. Solomon & House Judiciary & $\begin{array}{l}\text { Hsc Administrative Law and } \\
\text { Governmental Relations }\end{array}$ & $\begin{array}{c}\text { Referred to House subcommittee on } \\
\text { Administrative Law and Governmental } \\
\text { Relations }\end{array}$ \\
\hline $\begin{array}{c}\text { White Sands Fair } \\
\text { Compensation Act of } 1991\end{array}$ & S.867 & EDC & $4 / 18 / 91$ & Sen. Domenici & $\begin{array}{c}\text { Senate Energy and Natural } \\
\text { Resources }\end{array}$ & $\begin{array}{l}\text { Ssc Energy Conservation and } \\
\text { Supply }\end{array}$ & $\begin{array}{l}\text { Referred to Senate subcommittee } \\
\text { Public Lands, National parks }\end{array}$ \\
\hline
\end{tabular}


Appendix 1 (Continued)

\begin{tabular}{|c|c|c|c|c|c|c|c|}
\hline Title & Bill \# & Type $^{\mathrm{a}}$ & Date $^{b}$ & Sponsor & Referral Committee(s) & Referral Subcommittee(s) & Final Action \\
\hline $\begin{array}{c}\text { Just Compensation Act of } \\
1991\end{array}$ & H.R.2185 & $\mathrm{TC}$ & $5 / 1 / 91$ & $\begin{array}{l}\text { Rep. Smith, } \\
\text { R.F. }\end{array}$ & $\begin{array}{c}\text { House Merchant Marines and } \\
\text { Fisheries } \\
\text { House Public Works and } \\
\text { Transportation } \\
\text { House interior and Insular } \\
\text { Affairs }\end{array}$ & $\begin{array}{c}\text { Hsc Water Resources } \\
\text { Hsc Fisheries and Wildlife } \\
\text { Conservation and the Environment } \\
\text { Hsc Oceanography, Great Lakes, } \\
\text { and the Outer Continental Shelf } \\
\text { Hsc National Parks and Public } \\
\text { Lands }\end{array}$ & $\begin{array}{l}\text { Referred to House subcommittees: } \\
\text { National Parks and Public Lands; } \\
\text { Fisheries and Wildlife Conservation } \\
\text { and the Environment; Oceanography, } \\
\text { Great Lakes, and the Outer Continental } \\
\text { Shelf; Water Resources }\end{array}$ \\
\hline \multicolumn{8}{|c|}{$103^{r d}$ Congress, 1993-1994 } \\
\hline $\begin{array}{l}\text { Bill to compensate owners of } \\
\text { property substantially } \\
\text { diminished in value as a } \\
\text { consequence of a final } \\
\text { decision of any United States } \\
\text { agency }\end{array}$ & H.R.3784 & $\mathrm{TC}$ & $2 / 2 / 94$ & Rep. Smith, L & House Judiciary & $\begin{array}{l}\text { Hsc Administrative Law and } \\
\text { Governmental Relations }\end{array}$ & $\begin{array}{c}\text { Referred to House subcommittee on } \\
\text { Administrative Law and Governmental } \\
\text { Relations }\end{array}$ \\
\hline $\begin{array}{c}\text { Private Property Owners Bill } \\
\text { of Rights }\end{array}$ & H.R.3875 & $\mathrm{TC}$ & $2 / 23 / 94$ & Rep. Tauzin & $\begin{array}{c}\text { House Merchant Marine and } \\
\text { Fisheries } \\
\text { House Public Works and } \\
\text { Transportation } \\
\text { House Judiciary }\end{array}$ & $\begin{array}{l}\text { Hsc Administrative Law and } \\
\text { Governmental Relations } \\
\text { Hsc Environment and Natural } \\
\text { Resources } \\
\text { Hsc Water Resources and } \\
\text { Environment }\end{array}$ & $\begin{array}{c}\text { Referred to House subcommittees: } \\
\text { Administrative Law and Governmental } \\
\text { Relations; Environment and Natural } \\
\text { Resources; Water Resources and } \\
\text { Environment }\end{array}$ \\
\hline $\begin{array}{l}\text { Private Property Owners Bill } \\
\text { of Rights }\end{array}$ & S.1915 & $\mathrm{TC}$ & $3 / 9 / 94$ & Sen. Shelby & $\begin{array}{l}\text { Senate Environment and } \\
\text { Public Works }\end{array}$ & & $\begin{array}{l}\text { Referred to Senate environment and } \\
\text { Public Works committee }\end{array}$ \\
\hline $\begin{array}{c}\text { Private Property Rights Act } \\
\text { of } 1994\end{array}$ & S.2006 & TA & $3 / 25 / 94$ & Sen. Dole & Senate Governmental Affairs & & $\begin{array}{l}\text { Referred to Senate Governmental } \\
\text { Affairs committee }\end{array}$ \\
\hline $\begin{array}{c}\text { Private Property Rights Act } \\
\text { of } 1994\end{array}$ & H.R.4418 & TA & $5 / 12 / 94$ & Rep. Roberts & $\begin{array}{c}\text { House Government Operations } \\
\text { House Judiciary }\end{array}$ & $\begin{array}{l}\text { Hsc Legislation and National } \\
\text { Security } \\
\text { Hsc Administrative Law and } \\
\text { Governmental Relations }\end{array}$ & $\begin{array}{c}\text { Referred to House subcommittees: } \\
\text { Legislation and National Security; } \\
\text { Administrative Law and Governmental } \\
\text { Relations }\end{array}$ \\
\hline
\end{tabular}


Appendix 1 (Continued)

\begin{tabular}{|c|c|c|c|c|c|c|c|}
\hline Title & Bill \# & Type $^{\mathrm{a}}$ & Date $^{\mathrm{b}}$ & Sponsor & Referral Committee(s) & Referral Subcommittee(s) & Final Action \\
\hline $\begin{array}{l}\text { Private Property Rights } \\
\text { Restoration Act }\end{array}$ & S.2410 & $\mathrm{TC}$ & $8 / 19 / 94$ & Sen. Gramm & Senate Governmental Affairs & & $\begin{array}{l}\text { Referred to Senate Governmental } \\
\text { Affairs committee }\end{array}$ \\
\hline \multicolumn{8}{|c|}{$104^{\text {th }}$ Congress, 1995-1996 } \\
\hline $\begin{array}{l}\text { Job Creation and Wage } \\
\text { Enhancement Act of } 1995\end{array}$ & H.R.9 & $\mathrm{TC}$ & $1 / 4 / 95$ & $\begin{array}{l}\text { Rep. Archer, } \\
\text { Rep. Delay } \\
\text { Rep. Saxton } \\
\text { Rep. Smith, } \\
\text { Linda } \\
\text { Rep. Tauzin }\end{array}$ & $\begin{array}{c}\text { House Ways and Means } \\
\text { House Commerce } \\
\text { House Government Reform } \\
\text { and Oversight } \\
\text { House Budget } \\
\text { House Rules } \\
\text { House Judiciary } \\
\text { House Science } \\
\text { House Small Business } \\
\text { House Governmental Affairs }\end{array}$ & $\begin{array}{c}\text { Hsc Commerce, Trade, and } \\
\text { Hazardous Materials } \\
\text { Hsc Health and the Environment } \\
\text { Hsc Energy and Power } \\
\text { Hsc National Economic Growth, } \\
\text { Natural Resources, and Regulatory } \\
\text { Affairs }\end{array}$ & $\begin{array}{c}\text { Passed House }(3 / 3 / 95) \text { and referred to } \\
\text { Senate Governmental Affairs } \\
\text { committee }\end{array}$ \\
\hline $\begin{array}{l}\text { Private Property Protection } \\
\text { Act of } 1995\end{array}$ & H.R.130 & TA & $1 / 4 / 95$ & Rep. Solomon & $\begin{array}{l}\text { House Judiciary } \\
\text { House Agriculture }\end{array}$ & $\begin{array}{c}\text { Hsc Constitution } \\
\text { Hsc Deptartment Operations, } \\
\text { Nutrition, and Foreign Agriculture }\end{array}$ & $\begin{array}{l}\text { Referred to House subcommittees: } \\
\text { Constitution; Deptartment Operations, } \\
\text { Nutrition, and Foreign Agriculture }\end{array}$ \\
\hline $\begin{array}{c}\text { Private Property Rights Act } \\
\text { of } 1995\end{array}$ & S.22 & TA & $1 / 4 / 95$ & Sen. Dole & Senate Governmental Affairs & & $\begin{array}{l}\text { Referred to Senate Governmental } \\
\text { Affairs committee }\end{array}$ \\
\hline $\begin{array}{l}\text { Property Rights Litigation } \\
\text { Relief Act of } 1995\end{array}$ & S.135 & $\mathrm{TC}$ & $1 / 4 / 95$ & Sen. Hatch & Senate Judiciary & & Referred to Senate Judiciary committee \\
\hline $\begin{array}{l}\text { Private Property Rights } \\
\text { Restoration Act of } 1995\end{array}$ & S.145 & $\mathrm{TC}$ & $1 / 4 / 95$ & Sen. Gramm & Senate Governmental Affairs & & $\begin{array}{l}\text { Referred to Senate Governmental } \\
\text { Affairs committee }\end{array}$ \\
\hline $\begin{array}{l}\text { Property Rights Litigation } \\
\text { Relief Act of } 1995\end{array}$ & H.R.489 & $\mathrm{TC}$ & $1 / 11 / 95$ & $\begin{array}{l}\text { Rep. Smith, } \\
\text { Lamar }\end{array}$ & House Judiciary & Hsc Constitution & $\begin{array}{l}\text { Referred to House subcommittee on } \\
\text { Constitution }\end{array}$ \\
\hline $\begin{array}{l}\text { Private Property Owners Bill } \\
\text { of Rights }\end{array}$ & S.239 & $\mathrm{TC}$ & $1 / 18 / 95$ & Sen. Shelby & Senate Governmental Affairs & & $\begin{array}{l}\text { Referred to Senate Governmental } \\
\text { Affairs committee }\end{array}$ \\
\hline
\end{tabular}


Appendix 1 (Continued)

\begin{tabular}{|c|c|c|c|c|c|c|c|}
\hline Title & Bill \# & Type $^{a}$ & Date $^{\text {b }}$ & Sponsor & Referral Committee(s) & Referral Subcommittee(s) & Final Action \\
\hline $\begin{array}{c}\text { Private Property Protection } \\
\text { Act of } 1995\end{array}$ & H.R.925 & $\mathrm{TC}$ & $2 / 14 / 95$ & Rep. Canady & $\begin{array}{c}\text { House Judiciary } \\
\text { Senate Environment and } \\
\text { Public Works }\end{array}$ & & $\begin{array}{l}\text { Passed House (3/3/95) and referred to } \\
\text { senate Environment and Public Works } \\
\text { committee }\end{array}$ \\
\hline $\begin{array}{l}\text { Private Property Impact } \\
\text { Assessment Act of } 1995\end{array}$ & H.R.1277 & TA & $3 / 21 / 95$ & Rep. Condit & $\begin{array}{l}\text { House Judiciary } \\
\text { House Agriculture }\end{array}$ & $\begin{array}{c}\text { Hsc Constitution } \\
\text { Hsc Department Operations, } \\
\text { Nutrition, and Foreign Agriculture }\end{array}$ & $\begin{array}{l}\text { Referred to House subcommittees: } \\
\text { Constitution; Department Operations, } \\
\text { Nutrition, and Foreign Agriculture }\end{array}$ \\
\hline $\begin{array}{c}\text { Omnibus Property Rights Act } \\
\text { of } 1995\end{array}$ & S.605 & $\mathrm{TC}$ & $3 / 23 / 95$ & Sen. Dole & Senate Judiciary & & $\begin{array}{l}\text { Reported to Senate and placed on } \\
\text { legislative calendar }\end{array}$ \\
\hline $\begin{array}{l}\text { Endangered Species Act } \\
\text { Reform Act of } 1995\end{array}$ & S.768 & $\mathrm{TC}$ & $5 / 9 / 95$ & Sen. Gorton & $\begin{array}{l}\text { Senate Environment and } \\
\text { Public Works }\end{array}$ & & $\begin{array}{l}\text { Referred to Senate Environment and } \\
\text { Public Works committee }\end{array}$ \\
\hline $\begin{array}{l}\text { American Land Sovereignty } \\
\text { Protection Act of } 1996\end{array}$ & H.R.3752 & EDA & $6 / 27 / 96$ & Rep. Young & House Resources & & Failed Passage in House (9/26/96) \\
\hline $\begin{array}{c}\text { Omnibus Property Rights Act } \\
\text { of } 1996\end{array}$ & S.1954 & $\mathrm{TC}$ & $7 / 16 / 96$ & Sen. Hatch & & & $\begin{array}{l}\text { Second reading in Senate and placed } \\
\text { on legislative calendar }\end{array}$ \\
\hline \multicolumn{8}{|c|}{$105^{\text {th }}$ Congress, $1997-1998$} \\
\hline $\begin{array}{c}\text { Private Property Protection } \\
\text { Act of } 1997\end{array}$ & H.R.95 & TA & $1 / 7 / 97$ & Rep. Solomon & $\begin{array}{l}\text { House Judiciary } \\
\text { House Agriculture }\end{array}$ & $\begin{array}{l}\text { Hsc Dept. Operation, Nutrition, } \\
\text { and Foreign Agriculture } \\
\text { Hsc Constitution }\end{array}$ & $\begin{array}{l}\text { Referred to House subcommittee on } \\
\text { the Constitution }\end{array}$ \\
\hline $\begin{array}{l}\text { Bill to Amend the National } \\
\text { Wildlife Refuge System } \\
\text { Administration Act of } 1966\end{array}$ & S.491 & EDA & $3 / 20 / 97$ & Sen Ford & $\begin{array}{l}\text { Senate Environment and } \\
\text { Public Works }\end{array}$ & & $\begin{array}{l}\text { Referred to Senate Environment and } \\
\text { Public Works committee }\end{array}$ \\
\hline $\begin{array}{l}\text { Private Property Rights } \\
\text { Implementation Act of } 1997\end{array}$ & H.R.1534 & TA & $5 / 6 / 97$ & Rep. Gallegly & $\begin{array}{l}\text { House Judiciary } \\
\text { Senate Judiciary }\end{array}$ & $\begin{array}{l}\text { Hsc Courts and Intellectual } \\
\text { Property }\end{array}$ & $\begin{array}{l}\text { Passed House (10/22/97) and Report } \\
\text { No: } 105-242 \text { written by Sen. Hatch }\end{array}$ \\
\hline $\begin{array}{c}\text { Private Property Rights Act } \\
\text { of } 1997\end{array}$ & S.709 & TA & $5 / 7 / 97$ & Sen. Hagel & Senate Governmental Affairs & & $\begin{array}{l}\text { Referred to Senate Governmental } \\
\text { Affairs committee }\end{array}$ \\
\hline
\end{tabular}


Appendix 1 (Continued)

\begin{tabular}{|c|c|c|c|c|c|c|c|}
\hline Title & Bill \# & Type $^{a}$ & Date $^{\mathrm{b}}$ & Sponsor & Referral Committee(s) & Referral Subcommittee(s) & Final Action \\
\hline $\begin{array}{c}\text { Omnibus Property Rights Act } \\
\text { of } 1997\end{array}$ & S.781 & $\mathrm{TC}$ & $5 / 22 / 97$ & Sen. Hatch & Senate Judiciary & & Referred to Senate Judiciary committee \\
\hline $\begin{array}{l}\text { Private Property Owners Bill } \\
\text { of Rights }\end{array}$ & S.953 & $\mathrm{TC}$ & $6 / 24 / 97$ & Sen. Shelby & Senate Governmental Affairs & & $\begin{array}{l}\text { Referred to Senate Governmental } \\
\text { Affairs committee }\end{array}$ \\
\hline $\begin{array}{l}\text { Property Owners Access to } \\
\text { Justice Act of } 1997\end{array}$ & S.1204 & EDA & 9/23/97 & Sen. Coverdell & Senate Judiciary & & Referred to Senate Judiciary committee \\
\hline $\begin{array}{l}\text { Citizens Access to Justice } \\
\text { Act of } 1997\end{array}$ & S.1256 & EDA & $10 / 6 / 97$ & Sen. Hatch & Senate Judiciary & & Referred to Senate Judiciary committee \\
\hline $\begin{array}{c}\text { Property Rights } \\
\text { Implementation Act of } 1998\end{array}$ & S.2271 & EDA & $7 / 7 / 98$ & Sen. Hatch & & & $\begin{array}{l}\text { Cloture on motion to proceed not } \\
\text { invoked in Senate }\end{array}$ \\
\hline $\begin{array}{l}\text { Endangered Species Land } \\
\text { Management Reform Act }\end{array}$ & H.R.4554 & $\mathrm{TC}$ & $9 / 11 / 98$ & Rep. Thomas & House Resources & & $\begin{array}{l}\text { Referred to House Resources } \\
\text { committee }\end{array}$ \\
\hline
\end{tabular}

Source: Compiled from “Thomas: Legislative Information on the Internet." (http://thomas.loc.gov)

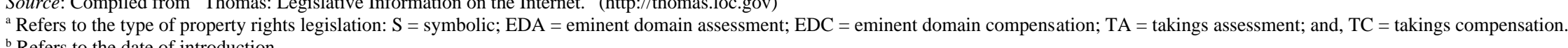




\section{Appendix 2: Interview Protocol}

I am conducting this interview to gain knowledge regarding the property rights issue. Your responses to the questions I ask will be used to lend insight to the issue and help explain its political circumstances. I will be taking notes during our conversation to ensure accuracy. Is this arrangement agreeable to you? Good.

The purpose of this study is to understand why state legislatures are enacting takings legislation. The focus of this study is the role played by the property rights community, but I am also interested in the broader policymaking process, of which agenda setting, issue definition, and venue shifting are a part. With few exceptions, the same questions are being asked of all person being interviewed. Is there anything else you would like to know before we begin? If not, let's proceed.

1. Was there a mobilization of property rights groups/advocates in the early 1980 s, mid1980s, and mid-1990s?

2. Have the types of groups advocating for property rights changed over the years?

3. Has the tone of the hearings concerning property issues changed over the years?

4. Have you had contact with congressional staff regarding the regulatory takings/property rights issue? Whose staff and how often?

5. Have you had contact with committee staff regarding the regulatory takings/property rights issue? Which committee's staff and how often?

6. Have you had contact with members of Congress regarding the regulatory takings/property rights issue? Which members and how often?

7. Have you been invited to testify at hearings concerning regulatory takings / property rights? Which hearings (bill number) and how many times? 
8. Have you written takings legislation? Type?

9. What were the members of the property rights community trying to accomplish through their testimonies at non-legislative hearings?

10. May congressional committees be classified as either "environmental" or "property rights" in regards to the regulatory takings issue (like in Table 2)? If so, is my classification of committee type accurate from your vantage?

11. Did the property rights community consciously move to shift the property rights battle to the states? Why, especially since they had gained access in Congress?

12. Why has there been very limited success in passing federal property rights legislation?

Note: This is the interview protocol I tried to follow with all the respondents. There were cases where I did not ask all the questions because of the time constraint the respondent was under. Also, the respondent would often speak extensively on a subject after being prompted by a question. Therefore, instead of interrupting the discussion to ask a question, I would often listen and take notes. I found that in most cases the respondent would address the questions I had through our open-ended discussion of the issue. 